Historic, Archive Document

Do not assume content reflects current scientific knowledge, policies, or practices. 

Ssc

\section{Seattle Seed} 1. Company's Complete Catalogue of
SEEDS
Poultry Supplies
Etc.

Office and Store at

319

First Avenue South

Seattle U.S.A. 


\section{...LIST OF CONTENTS...}

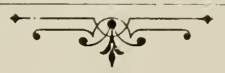

Page.

Page.

Artichoke Asparagus...........

60

Armour's Flower Food............

Auto Spray 47

Beans, Beets ............. 3-6

Bone Cutters, Grit Machines.....49-50

Books

$62-63$

Brocoli Brussels Sprouts

Broadcast Seed Sowers.

Brooders, Cyphers'............ 42

Cabbage ...............6- 7

Caponizers

46

Carrot, Cauliflowers...........

Celery, Chervil..............

Chicory Collards..............

Clipper Fanning Mills........... 54

Clover and Grass Seeds........22-25

Clover Cutters .............. 61

Corn ................. 9-10

Cress, Cucumber.............10-11

Dandelion Egg Plant.......... 11

Endive ................ 11

Fertilizers $\ldots \ldots \ldots \ldots \ldots \ldots \ldots \ldots$

Fly Knocker.............. 48

Flower Seeds.............. 26-38

Grafting Wax.............. 55

Grass and Clover Seeds........22-25

Hand Corn Planters........... 55

Herbs ................. 21

Incubators, Cypher's'. . . . . . . . 40-42

International Foods ........... 44

Kale, Kohl Rabi.............. 11

Lamberıs Insecticide........... 48

Lawn Mowers .............. 61
Leek, Lettuce.

Leg Bands.................. 50

Melons ...................13-14

Mushroom, Mustard, Nasturtum... 14

Nest Eggs................... 61

Nitro Culture................ 39

Okra or Gumbo............... 14

Onions, union Sets, Parsley...... 15

Parsnip, Peas..............15-17

Pepper, Pumpkin............. 17

Planet, Jr., Tools............. 51-54

Plants, Bushes.............25-26

Plants, Bushes............... 38

Poultry Foods............... .43-46

Poultry Netting............. . 50-51

Poultry Punch............... 45

Poultry Supplies..............42-46

Pruning Tools................ 54

Radishes, Rape.............17-18

Raffia ................. 55

Reddick Mole Trap............ 55

Rhubarb, Salsify, Spinage....... 18

Spray and Spray Materials....... 59

Spray Pumps.............. . 56-59

Squash, Sugar Cane............ 19

Sunflower, Tobacco............. 19

Thermometers ............ 46

Tobacco Dust ............... 60

Tomatoes $\ldots \ldots \ldots \ldots \ldots \ldots \ldots . \ldots 20$

Tree Labels ................... 55

Turnip ................. 20-21

Wilbur's Foods.............. 46

Weeders .................. 55

Wilson Dry Bone Mills......... 61

\section{Special Offer: For $\$ 1.00$ you can select SpeClal OHfer, any 25 Papers of our regular}

5c. Garden and Flower Seed packages, or you can select 12 Papers for 50c. All postage paid. 
We Make a Specialty of Hardy Northern Grown

Seeds Adapted For This Climate As

Well As Alaska.

\section{SEATTLE SEED CO'S. PRICED CATALOGUE FOR 1907}

319 First Avenue South SEATTLE, WASHINGTON.

\section{PRICES SUBJECT TO CHANGE WITHOUT NOTICE.}

Order Sheets-Each Catalogue is provided with an order sheet and addressed envelope. Please use these in making out and mailing your order. Write so plainly that there can be no mistake as to your name, your address or your shipping directions.

Prices-All seeds are sent by mail or express at our expense, at the prices stated, except where noted under different heads. The prices given for Io, 25 and roo pound lots do not include freight, which must be paid by the party ordering.

How to Send Money-Remittances may be made by any of the following methods: By Post-Office Money Order, by Bank Draft, by Express (by this method all charges must be prepaid,) by Express Company's Money Order (this is the best and safest' plan) or by Registered Letter (this is the least desirable method.) Money should never be sent loose in an unregistered envelope.

We use the greatest care to furnish seeds that are pure and reliable, but do not warrant them in any particular. If the purchaser does not accept them on these terms, they are at once to be returned.

H, SCHUETT, Proprietor and Manager.

SEATTLE SEED CO. 


\section{VALUABLE TABLES.}

Quantity of Seed Required to Sow an Acre of Ground.

Lbs. to the acr 25 to 30 125 to 130

Barley-Broadcast

Beans, Dwarf or Bush-Hills

Beans, Dwarf or Bush-Drills

Beans, Tall or Pole-Hills

Beet, Garden-Drills

Beet, Field-Drills

Broom Corn-Drills

Buckwheat-Broadcast

Cabbage, in beds to cover an acre after transplanting

Carrot-Drills

Clover, Red-Broadcast

Clover, White-Broadcast

Clover, Alsike-Broadcast

12 to 15

8 to 10

6 to 8

Corn, Sweet or Field-Hills

Corn, to cut green for fodder-Drills or Broadcast

Cucumbers-Hills

Flax, when wanted for seed

Flax, when wanted for fiber

Grass, Kentucky Blue, for pasture.

30 to 50

Grass, Kentucky Blue, for lawns.

100 to 125

Grass, Orchard

Grass, English or Australian Rye, for meadows

Grass, English or Australian Rye, for lawns.

Grass, Italian Rye

Grass, Red Top

Grass, Timothy

Grass, Meadow Fesque, or English Blue

Grass, Mesquite, in the chaff

Grass, Hungarian

Grass, Millet

Grass, Millet, for seed

Grass, Mixed Lawn

A much larger quantity of Seed is required to make a fine Lawn that for other purpose.

Grass, Mixture for mowing or grazing

Hemp-Broadcast

Clover

Timothy

Red Top

75 to 100

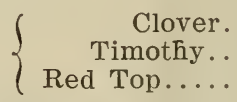 $\ldots \ldots .8$

Melon, Musk-Hills

Oats-Broadcast

Onion, Black Seed-Drills

Onion, Bottom Sets-Drills

Onion, Black Seed, for Bottom Sets

Parsnip-Drills

Peas-Drills

Peas-Broadcast

Potatoes-Hills

Pumpkins-Hills

Radish-Drills

Rye-Broadcast

Sage-Drills

Spinach-Drills

Squash, bush varieties-Hills

Squash, running varieties-Hills

Sugar Cane, if for sugar

Sugar Cane, if for fodder

70 to 80

Tomato, in beds to transplant

$1 / 8$ to $1 / 4$

Turnip and Ruta-baga-Drills

$11 / 2$ to 3

Turnip and Ruta-baga-Broadcast

Vetches-Broadcast

Wheat-Drills 


\section{VEGETABLE SEED :: :: DEPARTMENT ::::}

The object of this department is to describe all the known and approved food vegetables (with their seeds) of the subtropical and temperate zones; but duplicates of varieties which differ from each other only in name are discarded, as well as those varieties which, after years of trial, are found to be of no special or distinctive value. Iong lists of so-called varieties may prove as perplexing and deceptive to the practical grower as they are showy in the pages of a catalogue.

\section{ARTICHOKE}

IARGE GRIEN GIOBE-The variety used as a table vegetable. The edible portion is the thick end of the leaf of the flower head, cooked like asparagus. Sow early, in drills one foot apart, and. when about ten inches high, transplant into rows four feet apart each way. It will produce only a small crop the first year, but will continue in good bearing five years. Cut before the bud opens.

Pkt., 5c; oz., 35c; 2 oz., 60c; 1/4 1b., 95c; 1b., \$3.25.

\section{ASPARAGUS}

One of the first and most healthful of early spring vegetables. Soak the seed twenty-four hours in warm water, and sow in drills one foot apart. An ounce of seed will sow about thirty feet of drill. Keep the soil mellow and free from weeds. After one year's growth, transplant a foot apart, in rows about three feet apart. The crown of the plant should be six inches below the surface. Keep the soil loose, manure heavily, and give an annual dressing of salt when the plant is dormant.

CONOVER'S COIOSSAI-The standard variety, on account of its large size, great productiveness, and superior quality.

Plt., 5c.; 0z., 10c; 2 oz., 15c; $1 / 4$ 1b., 20c; 1b., 60c

COTUMBIAN IMAMMOTH WHITE-A newer and distinct and valuable variety. The stalks are white, of the largest size; very productive and early.

Pkt., 5c; oz., 10c; 2 oz., 15c; 1/4 1b., 25c; 1b., 75c

PAIMITTO-About the same size as Colossal, quite early, and shades towards bright green in color.

Pkt., 5c; Oz., 10c; 2 oz., 15c; $1 / 4$ Ib., 25c; 1b., 65c

\section{BEANS}

[When beans by the pound are wanted by mail or express, prepaid remit 10 cents per pound, to cover charges; 10,25 , and 100 -pound lots at buyer's expense for freight.]

Plant, after danger of frost is past, in rich, mellow loam, or highly manured soil, finely pulverized. The bush varieties yield best when planted four to six inches apart in two and onehalf to three foot rows. Keep the ground moist, and cultivate thoroughly, being careful not to
The following-named varieties may be relied on as distinctive and valuable, and the directions given for culture, if practically followed, will insure success.

we constantly add to our stock all the new varieties appearing from time to time if they prove of sufficient merit to warrant us to recommend them to the public.

work among nor handle them when wet or damp with rain or dew.

\section{Dwarf or Bush Green Podded Kinds}

[10 cents a pound extra if sent by mail or express prepaid.]

EXTRA EARIY RED VALENTINE, IMPROVIDD ROUND POD-Is of healthy, vigorous growth, and has no superior in any respect among the green-podded kinds. The pods are round, very fleshy, tender, and rich. The bean is rather small. and, when ripe, usually irregular in form and red in color.

Pkt., 10c; 1b., 15c; 10 to 25 lbs., 121/2c per 1b.

[10 cents a pound extra if sent by mail or express prepaid.]

EARIY IMOHAWK-The hardiest of the bush kinds, and may safely be planted a week earlier than any other. The pods are pale green, large, and broad. The vines continue in bearing a long time, and will withstand a light frost. The bean is large, dark purple and brown mottled.

Pkt., 10c; 1b., 15c; 10 to 25 lbs., 10c per 1b.

EARIY IONG YEIIOW SIX WEEKS-A standard variety; vines vigorous and productive, pods very long and tender when young. The bean is long, and of a rich brownish yellow color.

Pkt., 10c; 1b., 15c; 10 to 25 lbs., $10 \mathrm{c}$ per $1 \mathrm{~b}$.

EARIY ROUND YELIOW SIX WEERS IMPROVED ROUND POD-Thick, fleshy pods, and quite stringless; very early and hardy; superior to the old Yellow Six Weeks. Dry beans are yellow drab, and nearly round.

Pkt., 10c; 1b., 15c; 10 to 25 Ibs., 10c per Ib.

EXTRA FARIY REFUGIE-Said to be the earliest green-podded variety, fit for the table two weeks in advance of the old Refugee, and retaining all the good qualities of that standard sort.

Pkt., 10c; 1b., 15c; 10 to 25 Ibs., 121/2c per 1b.

REFUGEE Or THOUSAND TO ONE-The best late kind for snaps, and very productive. The pods are dark green, veined with purple, tender, and crisp, and considered the best variety for pickling. The bean is rather small, oblong, dark purple to black, mottled with light yellowish brown.

Plt., 10c; 1b., 15c; 10 to 25 Ibs., 10c per 1b. 


\section{BEANS-Continued}

Dwarf or Bush Green Podded Kinds.

BROAD WINSOR-Also known as Horse Beans. Stock erect, strong, and shrubby. The bean is large, broad, and flat; it is best green shelled. To insure well-filled pods, pinch off the top of the stock and the ends of the shoots when the pods are forming. A very popular table vegetable in European countries.

Plkt., 10c; 1b., 15c; 10 to 25 lbs., 6c per $1 \mathrm{~b}$.

STRINGIESS GREIN POD-A valuable addition to the green-podded sorts; extra early, round, fleshy poods; very brittle, and almost entirely stringless.

Plkt., 10c; 1b., 15c; 10 to 25 lbs., 121/2c per $1 b$.

\section{Dwarf Lima Beans}

[10 cents a pound extra if sent by mail or express prepaid.]

HENDERSON'S BUSF IIMA-A small Lima Bean, early and prolific; desirable for early use, but not equal in quality to the different Large Limas.

Pkt., 10c; 1b., 15c; 10 to 25 lbs., $12 \mathrm{c}$ per $1 \mathrm{~b}$.

\section{Dwarf or Bush Wax, Yellow- Podded Kinds}

[10 cents a pound extra if sent by mail or express prepaid.]

EXTRA EARIY CHAIIENGI BIACK WAXExtremely early about a week in advance of any other wax variety, and considered the most desirable for first crop. The plants are vigorous and very productive; the pods resemble those of the Prolifiic German Wax, but are a little flatter. Ripe beans medium size, jet black.

Pkt., 10c; 1b., 15c; 10 to 25 Ibs., 121/2c per Ib.

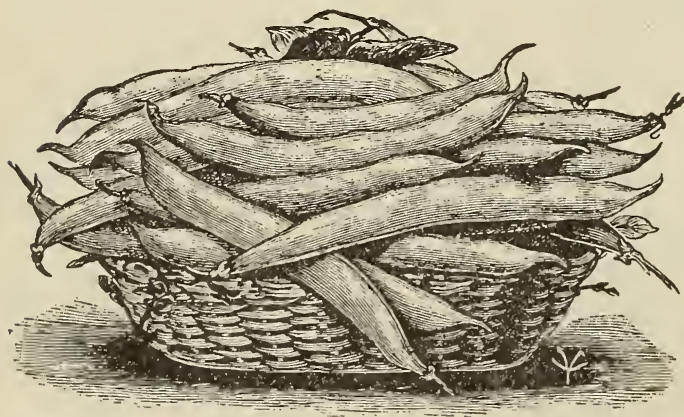

GOLDEN WAX-A standard wax variety, earlier than the old wax kinds. The pods are stringless, very tender, and excellent. The bean is of medium size, purple and white marbled, and one of the best quality, green shelled or dry.

Pkt., 10c; 1b., 15c; 10 to 25 lbs., 121/2c per 1b.

DAVIS WAX-A hardy, rustless, and immensely productive bush variety. The pods are long, nearly straight. white, and handsome; cooked when young they are tender, juicy, and of fine flavor. The dried bean is kidney shaped, clear white, and a favorite for baking and canning. Popular with canners and market gardeners.

Plkt., 10c; 1b., 15c; 10 to 25 Ibs., 121/2c per 1b.
WARDWIII'S KIDNEY WAX - A robust, hardy variety, yielding a heavy crop of large, unusually handsome, wax-like pods. They are fleshy, tender, and excellent, and are ready for the table earlier than any other wax kind, except the Black-eyed Wax. The bean, which is white with dark markings around the eyes, is larger than most other wax beans.

Pkt., 10c; 1b., 15c; 10 to $25 \mathrm{Ibs}, 12 \frac{1}{2} \mathrm{c}$ per $1 \mathrm{~b}$.

RUST-PROOF or DETROIT WAX-Excelling in some respects any other wax variety. Is not likely to rest, even when exposed to very wet weather. Pods flat, good length, and very broad. Its quality of keeping fresh and crisp a long time after being picked makes it valuable for shipping long distances. It is extra early, quality in the pod all that can be desired, and also excellent green shelled.

Pkt., 10c; 1b., 15c; 10 to 25 1bs., 121/2c per 1b.

GERMAN WAX, WHITE SFFDED-Much resembling the Black Seeded, except that the pods are larger. The bean, being white, is preferred by some dry for winter use.

Pkt., 10c; 1b., 15c; 10 to 25 lbs., 121/2c per 1b.

PROIIFIC GERIMAN WAX, BIACK SFEDED - This is a new kind, and an improrement on the German Wax. It is very prolific, yielding a larger crop than any other bush variety. The pods are large, of a creamy color, and good quality. The bean is rather small and glossy black

Plkt., 10c; 1b., 15c; 10 to 25 lbs., 121/2c per 1b.

\section{Pole or Running Varieties}

The pole or running kinds require greater car than the dwarf or bush varieties, but continue ir bearing all summer, and yield a much larger crop They should be planted in rich, mellow soil, il hills four feet apart each way, and well supporter with frames or poles firmly placed in the grounc Plant five or six beans in each hill, but allow onl: three or four vigorous plants to mature.

WHITE CREASE-BACK-Tines not as large a: some other kinds, but very productive. The pods which are produced in large clusters, are rounc fleshy, of superior quality, mature early, an stand shipping any required distance. The bea is small. White, very firm, and excellent dr: shelled.

Pkt., 10c; 1b., 15c; 10 to 25 1bs., 10c per 1b.

SOUTHERN PROIIFIC-A very productiv kind, continuing in bearing until frost. The pod are very tender, as they grow rapidly, and ar ready for the table earlier than any other po] variety. They are produced usually in clusters $c$ four, and are in every respect superior as snap The bean is small, and of a dark dun color.

Pkt., 10c; 1b., 15c; 10 to 25 lbs., 10c per $1 b$.

KENTUCKY WONDER OI OID HOMESTEADA vigorous, good climber, very prolific, bearir in clusters extremely long and very fleshy, su. culent pods, round, thick, and remarkably tende Dry beans are dun colored, long, and oval. A firs class pole variety.

Pkt., 10c; 1b., 15c; 10 to 25 lbs., 10c per $1 b$. 


\section{BEANS-Continued}

DUTCH CASE KNIFE-Produces large, flat is handsomely variegated with dark purple and pods, that are excellent for snaps, cut young. The bean is white, large, flat, and of superior qual-

ity green shelled or dry.

Pkt., 10c; 1b., 15c; 10 to 25 lbs., 10c per 1b.

LONDON HORTICUITURAI OT SPECKLED CRANBERRY-Very desirable for the family garden. Vines vigorous, bearing light green pods, streaked with red. The bean is large, oval, creamcolored. beautifully splashed with red, and has no superior for cooking, eitler green slielled or dry.

Plat., 10c; 1b., 15c; 10 to 25 lbs., 10c per 1b.

SCARLET RUNNER-A rapid grower, cultivated both for its beautiful scarlet blossoms and for table use. The pods have an approved flavor of their own, cooked as snaps, when about threefourths grown; the most popular of all string beans in England. The bean, which is very large,

black, and is used by many green shelled.

Plat., 10c; 1b. $25 \mathrm{c}$

\section{Pole or Running Lima Beans}

IARGE WHITE IIMA-A tall, slender, vigorous vine, bearing smooth, light-green leaves, white blossoms, and pods in clusters. The pods are long, broad. and thin, the beans large, kidney shaped, flat, and unsurpassed in quality, green shelled or dry. This variety comes to its highest state of perfection in the rich valleys of the Pacific Coast and in the Southern States, where it continues long in bearing, producing a large crop.

Pkt., 10c; 1b., 15c; 10 to 25 lbs., 12c per 1b.

KING OF THE GARDEN IIMA-Larger pods and larger beans than the Large White Lima. Quite a favorite with market gardeners.

Pkt., 10c; 1b., 15c; 10 to 25 1bs., 12c per 1b.

\section{BEETS}

\section{For Table Use}

The Beet' is hardy, and may be planted as soon as the ground can be well prepared, doing best in rich, sandy soil, sown in rows of sixteen nches apart, covered one and one-half inches leep. The seed will sprout better if soaked twenty-four hours in warm water before planting. Thin out by using the largest ones when they are of sufficient size. continuing until they are six or eight inches apart in the row. For field crop, the rows should be far enough apart to permit the use of a horse cultivator.
EXTRA FARIY ECLIPSE BLOOD TURNIPIn improved early kind, having a small top and aproot. The flesh is bright and dark red, tenler, and sweet. It attains a good size without be:oming woody, and is a good keeper.

?kt., 5c; oz., 10c; 2 oz., 15c; 1/4 1b., 20c; 1b., 60

EARIY EGYPTIAN BIOOD TURNP-Excelent for forcing, maturing early; of medium size, lattened on top; flesh deep red, fine grained, and weet; best used when young.

'kt., 5c; oz., 10c; 2 oz., 15c; 1/4 1b., 20c; 1b., 60c

EARIY BASSANO BLOOD TURNIP-This vaiety produces a large top and leaf stalks that is. re excellent cooked with the young roots. They ecome coarse and tasteless with age. Flesh ight red, shaded with circles of white.

t., 5c; oz., 10c; 2 oz., 15c; 1/4 1b., 20c; 1b., $50 \mathrm{c}$.

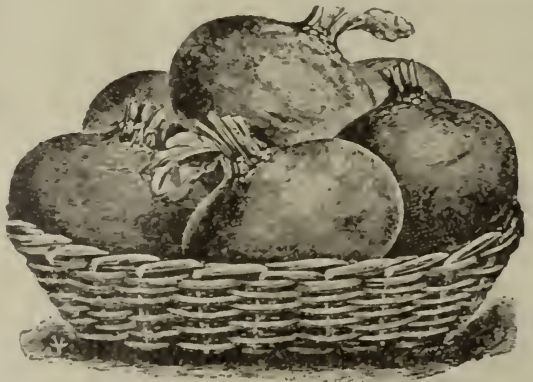

FARIY BIOOD RED TURNIP-A leading Irnip-shaped variety, of medium size, rapid growth, not liable to become woody, keeps well. Flesh bright red, tender, and sweet.

Pkt., 5c; oz., 10c; 2 oz., 15c; 1/4 1b., 20c; 1b., 50c.

CROSBY'S EXTRA EARIY EGYPTIAN BIOOD TURNIP-Very early, large, globular, somewhat lighter colored than the above, and of fine tissue and flavor.

Pkt., 5c; oz., 10c; 2 oz., 15c; 1/4 1b., 20c; 1b., 60c.

EDMAND'S EARIY BLOOD TURNIP-Dark red flesh, zoned with a lighter shade; very crisp and tender; keeps sufficiently well to be used as either a summer or winter variety; very desirable addition to the list of turnip-shaped sorts.

Pkt., 5c; oz., 10c; 2 oz., 15c; 1/4 1b., 20c; 1b., 60c.

DARK RED TURNIP-Has several attractive features, and is considered by some the best variety: Globular, smooth, handsome, uniform in shape, with smail tops; it matures early and lasts long; flesh sweet, crisp, and tender. Superior for home use; a favorite with market gardeners and excellent for canning purposes.

Pkt., 5c; oz., 10c; 2 oz., 15c; 1/4 1b., 20c; 1b., 60c.

HAIF LONG BLOOD RED-One of the very best for winter use; does not become woody, and keeps equally as well as the Long Dark Blood. The root is smooth and handsome, and the flesh as brilliant in color and good in quality as the best Blood Turnip varieties. TVe recommend our customers to give it a trial.

Pkt., 5c; oz., 10c; 2 oz., 15c; $1 / 4$ 1b., 20c; 1b., 60c.

IONG SMOOTH DARK BIOOD-The leading late variety, keeping well all winter. Should be planted in rich, warm soil to secure rapid growth, which makes it tender. Top small, root long and smooth; flesh deep purple; fine, and sweet.

Pkt., 5c; oz., 10c; 2 oz., 15c; $1 / 4$ 1b., 20c; 1b., $50 \mathrm{c}$. 


\section{BEETS-Continued}

SWISS CHARD SIIVER OT SEA TAIE BEET -Cultivated exclusively for its leaves and leaf stalk, which are prepared and served similar to asparagus, and are tender and delicious. If cut frequently, the young leaves reappear and make excellent greens, taking the place of spinach.

Plst., 5c; oz., 10c; 2 oz., 15c; 1/4 1b., 20c; 1b., 50c.

\section{Beets For Stock Feeding}

(25-1b. lots at buyer's expense for freight.)

IONG RED MANGEI WURZEI-A large variety, producing an enormous crop. Grows much abow ground; flesh white, shaded with red. Grown mostly for stock feeding, but used for the table when young.

Pkt., 5c; 0z., 10c; 2 oz., 10c; 1/4 1b., 15c; 1b., 35c; 25 lbs., $16 \mathrm{c}$ per $1 \mathrm{~b}$.

IMPROVED MAMMOTI IONG RED MANGEI WURZEI-An improvement on the Long Red Mangel Wurzel. Roots of more uniform shape; flesh darker in color and generally better relished by stock. Produces an enormous crop.

Plkt., 5c; oz., 10c; 2 oz., 10c; $1 / 4$ 1b., 15c; 1b., 35c; 25 lbs., 16c per $1 \mathrm{~b}$.

YEIIOW GIOBE MANGEI WURZEI-An excellent, large, orange-colored variety; very productive and a good keeper. Particularly adapted for growing on shallow soil.

Prt., 5c; 0z., 10c; 2 oz., 10c; 1/4 Ib., 15c; 1b., 35c; 25 lbs., 16c per lb.

YELIOW GIANT INTERMEDIATE, IEVIATHAN, OR GATE POST-An improved variation from Yellow Ovoid; smooth skin; sweet, firm flesh; heavy cropper and good keeper.

Pkt., 5c; oz., 10c; 2 oz., 10c; 1/4 Ib., 15c; 1b., 35c; 25 Ibs., 16c per Ib.

YFITOW OVOID MANGFI WURZFI-Similar to the Yellow Globe, but grows to a much larger size, and more of a half-long shape. Yields an enormous crop. One of the most desirable stockfeeding mangels.

Pkt., 5c; 0z., 10c; 2 oz., 10c; 1/4 Ib., 15c; 1b., 35c; 25 Ibs., 16c per Ib.

GOIDEN TANKARD MANGET WURZELOvoid in shape, grows to a large size, and produces an astonishingly large crop. Flesh of a bright yellow, very nutritious, and said to be preferred by stock to any other. Can be grown successfully on shallower soil than Long Red Mangels, and is more easily gathered.

Pkt., 5c; oz., 10c; 2 oz., 10c; 1/4 1b., 15c; 1b., 35c; 25 lbs., 16c per 1b.
FRENCF WHITE SUGAR RED TOP-Larg and excellent. The flesh is of a fine grain, ten der, and sweet. Rich in sugar, and very produc tive. Superior for stock feeding, and sometime used for the table when young.

Pkt., 5c; oz., 10c; 2 oz., 10c; $1 / 4$ 1b., 15c; 1b., 35c 25 lbs., 16c per 1b.

IANE'S IMPERIAI SUGAR-An improved va. riety of the French Sugar Beet, recommended as being hardier and as containing more sugar thar the old variety. Large and excellent for stock.

Pkt., 5c; Oz., 10c; 2 oz., 10c; 1/4 1b., 15c; 1b., 35c $25 \mathrm{lbs}$., 16c per $1 \mathrm{~b}$.

\section{Beets For Sugar Making}

(25 lbs. and over at buyer's expense for freight.)

VIIMORIN'S IMPROVED WHITE SUGAR-A medium-sized white Sugar Beet, claimed to be the result of scientific selection from sugar-producing varieties. Uniform in size, form, and color, anc of a high percentage of sugar.

Pkt., 5c; oz., 10c; 2 oz., 10c; 1/4 1b., 15c; 1b., 35c: 25 lbs., 17c per 1b.

KIEIN WANZIEBEN ON GERMAN IMPERIAI WHITE SUGAR - This is the variety mostly grown in California, for use in the manufacture of sugar. It gives the best results raised in sandy soil free from alkali. It is very profitable as a Sugar Beet. Hardier and more easily handled than Vilmorin's.

Pkt., 5c; Oz., 10c; 2 oz., 10c; 1/4 1b., 15c; 1b., 35c: 25 Ibs., 17c per Ib.

\section{Broccoli}

Broccoli is a species of cabbage so nearly resembling the cauliflower as to be hardly distinguishable from it, being, however, taller, hardier, and more easily grown. Treatment and cultivation the same as for cauliflower.

FARIY WHITF FRENCF is the best variety. Vigorous and hardy; heads hard, white, compact. and durable.

Pkt., 5c; oz., 35c; 2 oz., 60c; 1/4 Ib., $\$ 1.00$

\section{Brussels Sprouts}

Cultivated for the small heads, which are very sweet and of excellent quality, growing in great numbers on the tall stem of the plant. Particularly valuable for our California climate, as a few plants will supply a constant succession during the whole season. Cultivate the same as cabbage.

DWARI, IMPROVED-The best. Produces abundantly. Break away the spreading leaves at the top of the plants when the sprouts begin to form.

Pkt. 5c; oz., 20c; 2 oz., 30c; $1 / 4$ Ib., 50c; 1b., $\$ 1.50$

\section{CABBAGE}

Cabbage is the most universally cultivated of all garden vegetables, and will thrive in almost any soil, but, to bring it to the greatest perfection, the soil should be deep, rich, and moist. For early use, sow in hotbed or cold frame in winter or very early in the spring. For general culture, sow in beds and transplant, the early varieties one and a half to three feet apart, and the large, late kinds, three to four feet apart each way.

\section{Early or Spring Varieties}

EARIY JERSEY WAKEFIELD-The variety so popular in the New York market. Heads conical, of medium size, firm, very crisp, and tender. Early and a sure header.

Plkt., 5c; oz., 25c; 2 oz., $40 \mathrm{c}$; $1 / 4$ 1b., $65 \mathrm{c}$; 1b., $\$ 2.00$ 


\section{CABBAGE-Continued}

\section{Early or Spring Varieties}

FARIY EXPRESS-A rapid grower, and held some to be the earliest in cultivation. It esembles somewhat the Jersey Wakeficld, but rather larger, not quite so pointed, and of a more creamy tint. The heads are firm, tender, and of fine quality.

Plkt., 5c; oz., 25c; \& oz., 40c; ${ }_{4}+1$ 1b., 65c; 1b., $\$ 2.00$

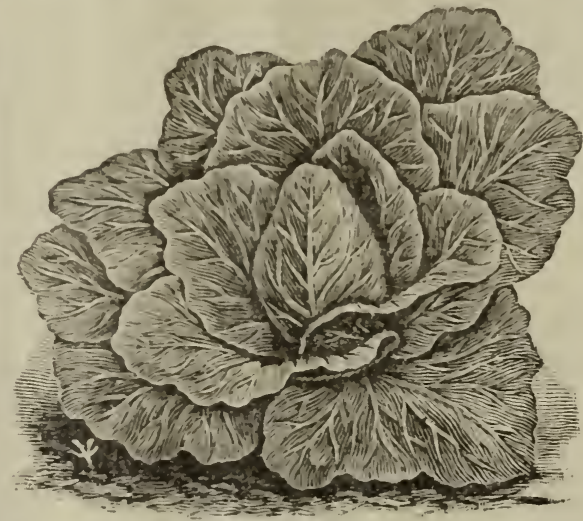

CHARIESTON ON IARGE WAKEFIELDarger and a little later than the Early Jersey Wakefield, but having the same general shape, xcept that it is less pointed. A good sort for narket gardeners

Pkt., 5c; oz., 30c; 2 oz., 40c; $1 / 4$ 1b., 65c; 1b., \$2.00

EARIY YORK-A leading early kind. Being ather small, it can be set closer than most othrs. The heads form rapidly, and are very tenler and sweet. Usually not quite as large as he Jersey Trakefield.

?kt., 5c; oz., 20c; 2 oz., 30c; 1/4 1b., 50c; 1b., $\$ 1.50$

\section{Second Early or Summer Varieties}

HENDERSON'S EARIX SUMOMER A strong rowing large header, somewhat conical in form: $i$ better keeper (i. e., less liable to burst) than the tverage of early sorts.

?kt., 5c; oz., 20c; 2 oz., 35c; $1 / 4$ lb., 60c; 1b., $\$ 2.00$ EARIY WINNIGSTADT-A desirable kind, laving conical, solid heads; a sure header unler almost any condition; keeps better, and is ess liable to suffer from blight, drought, or frost han most early varieties. Fine, and of excellent iuality.

?kt., 5c; oz., 20c; 2 oz., 35c; 1/4 1b., 60c; 1b., $\$ 2.00$

EARIY DRUMHEAD-A standard medium earvariety. Heads large, round, slightly flattened, nd excellent for the family or market garden. It loes not crack, and keeps till well on in the vinter.

?kt., 5c; oz., 20c; 2 oz., 35c; $1 / 4$ 1b., 60c; 1b., $\$ 2.00$ EARIT DWARF FIAT DUTCH-A medium arly kind, much resembling the Early Drumlead. It grows low on the stem, and is a sure leader; firm, fine grained, tender, and excellent. zeeps almost as well as the late kinds.

?kt., 5c; oz., 20c; 2 oz., 35c; $1 / 4$ 1b., 60c; 1b., $\$ 2.00$ SUCESSION-A medium early variety, prolucing large, round heads slightly flattened. which lo not crack readily, and are solid and of excelent quality.

?kt., 5c; oz., 20c; 2 oz., 35c; 1/4 lb., 60c; 1b., \$2.00

AIC SEASONS-Medium early, heads large, slightly flattened; grows low on the stem, and resembles the Early Summer, except that the

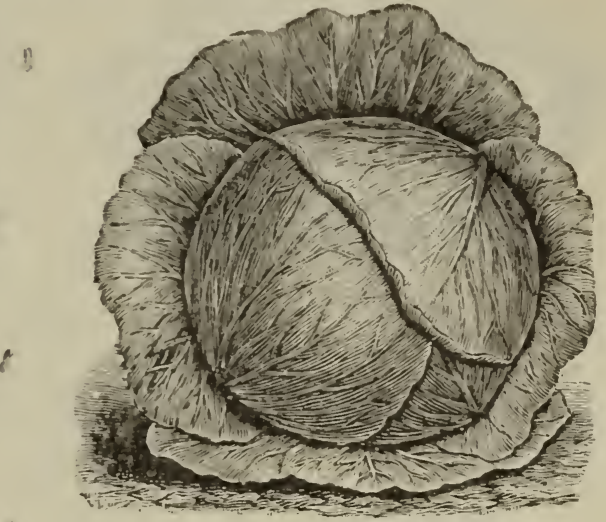

heads are usually larger, of fine flavor, tender, and sweet, and superior for all purposes. It is also a good keeper, and can be used as a fall and winter variety.

Pkt., 5c; oz., 20c; 2 oz., 35c; $1 / 4$ 1b., 60c; 1b., $\$ 2.00$ AII HEAD EARIY-An excellent early variety. Compact, round head; smooth, thick leaf; fikely to become a general favorite.

Pkt., 5c; oz., 20c; 2 oz., 35c; $1 / 4$ 1b., 60c; 1b., $\$ 2.00$

\section{Late Varieties}

IARGE IATE FIAT DUTCH-A hardy, vigorous, and sure-heading sort; large, handsome, and solid; none better as a late market variety, especially for shipping purposes and for long keeping.

Pkt., 5c; oz., 20c; 2 oz., 35c; $1 / 4$ lb., 55c; 1b., $\$ 1.75$

PREMIUM IATE FIAT DUTCH-A leading late variety. Produces large, round heads, flattened on top; heads sure to form, keep well, and of excellent flavor, tender, and sweet. One of the best late market kinds.

kt., 5c; oz., 20c; 2 oz., 35c; 1/4 1b., 55c; 1b., $\$ 1.75$

PREMIUM DRUMHEAD-An improvement on the Large Drumhead, grows lower on the stem, is larger, and matures earlier, but keeps quite as well and has no superior in any respect for all family and marketing purposes, either for medium early or late crop. The seed we offer is unsurpassed by any in the market.

Pkt., 5c; oz., 20c; 2 oz., 35c; $1 / 4$ lb., 55c; 1b., $\$ 1.75$

SUREHEAD-Remarkable both for its certainty to head and its ability to withstand drought. Compact, medium to large.

Pkt., 5c; oz., 20c; 2 oz., 35c; $1 / 4$ 1b., 55c; 1b., $\$ 1.75$

DANISE BAIL-HEAD OT HOILANDER-A very hard heading, late variety, enduring both frost and drought remarkably. Introduced from Denmark, and rapidly gaining in popularity. Plants produce a solid, round head. Keeping qualities of the best.

Pkt., 5c; oz., 20c; 2 oz., 35c; $1 / 4$ 1b., 60c; 1b., $\$ 2.00$ MARBIEHEAD MAMTOTH DRUMHEADThe largest variety known, cultivated mostly on account of its enormous size, usually averaging thirty pounds, but sometimes attaining double that weight. It is hardy and a good keeper, but coarser and not as well flavored as most other kinds. Its common English name of Cow Cabbage indicates one of the uses of this variety. Pkt., 5c; oz., 20c; 2 oz., 35c; $1 / 4$ 1b., 60c; 1b., \$2.00

RED DUTCH-Forms a small, round, solid head of a deep red or purple color. Hardy and keeps well; used mostly for pickling and salads.

Pkt., 5c; oz., 20c; 2 oz., 35c; $1 / 4$ 1b., 60c; 1b., $\$ 2.00$ DRUMREAD SAVOY-A large and firm variety of fine quality. leaves very much crinkled. The flavor is very much improved by a light frost. Pkt., 5c; oz., 20c; 2 oz., 35c; $1 / 4$ 1b., 60c; 1b., $\$ 2.00$ 


\section{CARROT}

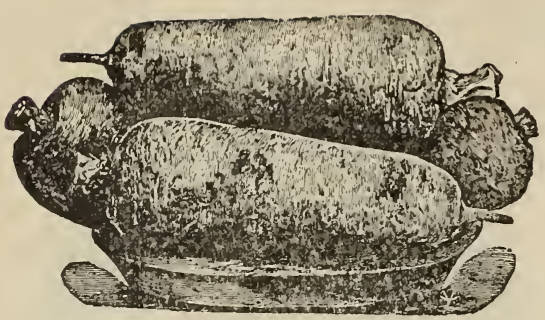

Sow as soon as the ground can be thoroughly prepared, in rows fifteen inches apart, and, when well up, thin to from four to six inches apart, according to the kind you are growing. The seed germinates slowly, requiring sometimes three weeks for the young plants to appear. To get a start of the weeds, soak the seed a day or two in tepid water, and roll it in sand, plaster, or wood ashes before sowing, or let the ground lie several days after it is prepared for the seed, when the weeds can be killed. The soil should be rich and loose, and it will produce smoother carrots if it is manured the year previous. Sow three pounds to the acre, or one ounce to one hundred and fifty feet of row.

Aariy FrFNCH rORCING HORN-The earliest, quickest growing, and best for forcing. The root is thick, but very short; flesh deep orange, fine grained and excellent; best for the table when not quite mature.

Pkt., 5c; oz., 10c; 2 oz., 15c; 1/4 1b., 25c; 1b., 85c

$\checkmark$ EARIY SCARLET HORN-The best early kind for general use. It is larger than the forcing variety, but fully as good in quality, and produces a much larger crop.

Pkt, 5c; oz., 10c; 2 oz., 15c; 1/4 1b., 25c; 1b., 70c

OX-FEART or GURRANDE-A new variety, having a small top, but rather large, thick, heartshaped root. The flesh is deep orange, fine grain- ed, and excellent, for either the table or stock feeding.

Pkt., 5c; oz., 10c; 2 oz., 15c; 1/4 1b., 25c; 1b., 70c

FARIY HALF-IONG SCARIET, STUMP ROOTED-A little later than the Horn varieties, but equal to them in grain and quality; has no hard core, and is not surpassed by any kind for either table use or stock feeding.

PItt., 5c; oz., 10c; 2 oz., 15c; 1/4. 1b., 25c; 1b., 65c

CFA TTraY For table use, one of the best in shape and finest in quality; half long uniformly stump rooted, and smooth; color deep orange red; flesh crisp and tender. Early and a heavy cropper.

Pky., 5c; oz., 10c; 2 oz., 15c; 1/4 1b., 25c; 1b., 65c

DANVERS ORANGE, HAIF IONG-In form about midway between Long Orange and Short Horn. It is of a rich, dark orange color, very smooth and handsome, and easier to dig than most carrots. First class in every respect, both for the garden and field crop.

Pky., 5c; oz., 10c; 2 oz., 15c; 1/4 1b., 25c; 1b., 65c

FINEST IONG ORANGE-The leading large, scarlet-fleshed variety, grown extensively for stock feeding, as well as for table use. For size of root, quality of flesh, and quantity of crop it has no superior. Requires a deeper soil than the short and half-long kinds.

Pkt/, 5c; oz., 10c; 2 oz., 15c; 1/4 1b., 20c; 1b., 60c

IARGE WHITE BEIGIAN-Extensively grown for stock feeding. The most productive of all Grows much above ground, so that the entire crop can be pulled by hand. The White Belgian has recently been much improved, in the same manner as the Finest Long Orange, and is now larger and of finer quality than formerly. The stock we offer has no superior.

Płst., 5c; oz., 10c; 2 oz., 15c; 1/4 lb., 20c; 1b., 45c

SHORT THICK WHITE-Half-long, thick, smooth, very productive, the heavier part aboveground the root tapering to the point, flesh of good flavor, white, solid, and crisp.

Pyt., 5c; oz., 10c; 2 oz., 15c; 1/4 1b., 20c; 1b., 50c

THORT WHITE VOSGES-Specially adapted for growing in shallow soils; short rooted, thick at the shoulder, easily handled, yields heavily; a growing favorite for stock feeding.

Pkt., 5c; oz., 10c; 2 oz., 15c; 1/4 lb., 20c; 1b., 50c

\section{CAULIFLOWER}

The cauliflower belongs to the cabbage family, and, from its superior qualities as a table vegetable, is a prime favorite. To insure success, a rich, moist soil should be selected. For early crop, start in hotbed; for later use, sow in open ground. transplanting to fifteen inches apart, in thirtyinch rows. Cultivate thoroughly, hilling up the earth around the stalks at each hoeing, and water well while the heads are forming.

FAIIY SNOWBAII-By many considered one of the best varieties. A sure header, producing handsome, round, firm heads, of excellent flavor and quality. Heads large, mature early, and keep well all winter.

Pkt., 5c; oz., \$1.50; 2 oz., \$2.50; 1/4. 1b., $\$ 4.50$

FXTRA FARIY DWARF FRTURT-Very dwarf, sure to head, and the earliest. The heads are of good size, pure white, very solid, of excellent quality, and delicate flavor.

Pkt., 5c; oz., \$1.25; 2 oz., \$2.25; 1/4 lb., $\$ 4.00$

EARIY IONDON-A leading early variety; a sure header, hardy, and easier of cultivation than many other kinds. The heads are large, solid, very white, tender and delicious.

Pkt., 5c; oz., 20c; 2 oz., 30c; 1/4 1b., $\$ 1.00$
FARIY PARIS-A popular early sort. The heads are large, white, tender and excellent. Early and compact growing. A favorite with market gardeners.

Pkt., 5c; oz., 50c; 2 oz., 90c; 1/4 lb., $\$ 1.65$

EARIY FAVORITE-A certain header; large, white heads; tender and delicately flavored. A standard variety for early or late crop, and a good keeper.

Pkt., 5c; oz., 65c; 2 oz., $\$ 1.25$; 1/4 1b., $\$ 2.00$

IENORIAND'S SHORT STEM - One of the largest and most reliable for general cultivation. The heads are well protected by leaves, so that it is particularly valuable for growing in dry, hot localities.

Pkt., 5c; oz., 65c; 2 oz., $\$ 1.25$; 1/4 1b., $\$ 2.00$

IARGE AIGIERS-Upright, large, a sure header; heads well protected by leaves in the event of frost; has no superior in quality as a late variety.

Pkt., 5c; oz., 70c; 2 oz., \$1.25; 1/4 lb., \$2.25 


\section{CELERY}

The sred germinates slowly, and slould be startecl in rich, mellow, open beds, in rows, to aroid crowding the young plants, and more easily keen them free flom weeds. When two or three inches high, transplant to furrows, and when eight to ten inches high, fill up the furrows, continuing at intervals to hill up till fully matured and blinched, taking care not to get earth between the stilks. The vigor and quality of the stock are improved by partially topping when trinsplnnting. (vultivate thoroughly, and keep well watered.

GIANT PASCAL-A new rariety. It is large and of unusually rapicl and rigorous growth. The stalks are easily blanched, frm, crisp and tender, of a beautiful golden tint. and possessing in a high degree the rich, nutty flavor which is the chief characteristic of superior quality. in this nopular salad plant. Our stock is the very best in the market.

Pkt., 5c; oz., 15c; 2 oz., 25c; 1/4 1b., 40c; 1b., \$1.25

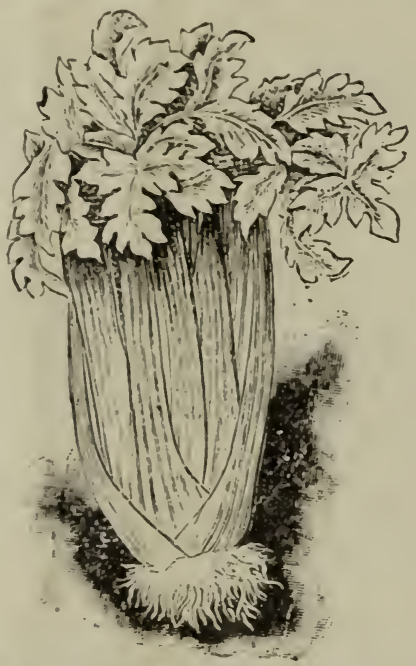

GOIDEN SEIF-BIANCHING-A variety somewhat resembling the White Plume, and, like it, requiring but little earthing up to secure perfect blanching. It is of a rich golden tint when ready for the table; very handsome and of excellent quality:

Plt., 5c; oz., 25c; 2 oz., 45c; 1/4 1b., 80c; 1b., \$2.75

GOLDEN-HEARTED DWARF-A new variet of great value: splendid keeper, remarkable for its fine quality. Heart of bright golden color.

Pkt., 5c; oz., 15c; 2 oz., 25c; $1 / 4$ 1b., 45c; 1b., $\$ 1.40$

IARGE WHITE SOIID-A standard variety, and one of the largest. A strong, vigorous grower, crisp. tender and of good flaror; firm, and keeps longer than most others.

Pkt., 5c; oz. 15c; 2 oz., 25c; $1 / 4$ lb., 40c; 1b., $\$ 1.25$
EVANS' TRIUMPH - A superior late kind; slow growing and a good keeper; large, crisp, white, sweet ind excellent.

Pkt., 5c; oz., 15c; 2 oz., 25c; $1 / 4$ 1b., 45c; 1b., \$1.40

HARTWEII'S PERFECTION-Not so large as Evans, but one of the best flavored varieties. The stalks are medium size, very crisp and tender, and of a fine, nutty flavor.

Pkt., 5c; oz., 15c; 2 oz., 25c; 1/4 lb., 45c; 1b., $\$ 1.40$

WHITE PLUME-A new variety; popular on account of its naturally white leaf stalks, which require less blanching than other kinds. Tie the tops together, and hill up the earth slightly. Its handsome, plume-like top is very ornamental on the table. It is quite early and a fine market sort.

Fkt., 5c; oz., 20c ; 2 oz., 30c ; $1 / 4$ 1b., 50c; 1b., $\$ 1.50$

DWARF WHITE SOIID-Remarkable for its keeping qualities. A standard variety of good flavor, solid, and crisp. Being dwarf, it can be planted closer together than most other kinds.

Pkt., 5c; oz., 15c; 2 oz., 25c; 1/4 1b., 40c; 1b., \$1.25

CEIERY SEED, FOR FIAVORING-Sed used for flavoring soups, stews, pickles, etc.

Oz., 10c; 2 oz., 10c; 1/4 1b., 15c; 1b., 30c

CELIRIAC OT TURNP-ROOTED CELERY-A variety having turnip-shaped roots. Which are used principally for seasoning meats and soups; also used for salads.

Iarge Smooth Prague.

Pkt., 5c; oz., 15c; 2 oz., 25c; 1/4 1b., 45c; 1b., $\$ 1.40$

\section{Chervil}

A sweet, aromatic plant, lised as a salad while young and tender, also as parsley for garnishing, seasoning soups, etc. Sow thinly early in spring in drills a half inch deep and one foot apart; as the plants grow, they may be thinned out, or transplanted, if desired.

CURIED-The principal variety grown.

Pkt., 5c; oz., 15c; 2 oz., 20c; $1 / 4$ oz., 30c; 1b., $\$ 1.00$

\section{Chicory}

Extensively used to adulterate coffee and as a substitute for it. The culture is the same as for carrots. Dig at about the same time as carrots, wash, slice and dry by artificial heat. The blanched leaves are used by some for salad.

IARGE ROOTED or COFFEE-The best kind. Plkt., 5c; oz., 10c; 2 oz., 15c; 1/4 1b., 25c; 1b., 80c

\section{Collards}

A species of cabbage, knorwn also as Cole, or Colewort, grown throughout the South for greens. Sow in autumn, in rows a foot apart, and treat the same as cabbage.

TRUE GEORGIA or SOUTHERN-The leading and best variety.

Pkt., 5c; oz., 15c; 2 oz., 20c; 1/4 1b., 30c; 1b., $\$ 1.00$

\section{CORN, SWEET OR SUGAR}

(When corn by the pound is wanted by mail or express, prepaid, remit $10 \mathrm{c}$ per $1 \mathrm{~b}$. extra, to cover charges; $10,2 \overline{5}$ and 100-1b. lots by freight, charges collect.)

Corn thrives best in warm, rich soil. The smaller varieties may be planted ten inches apart in drills made two and a half feet apart. The larg er kinds should be planted a foot apart in drills made three and a half feet apart, or may be planted in hills three and a half feet apart each way, allowing three or four stalks to remain in a hill; the latter is the usual way, though in drills the product is greater per acre. Success can only be secured by thorough cultivation. 


\section{CORN. SWEET OR SUGAR-Continued}

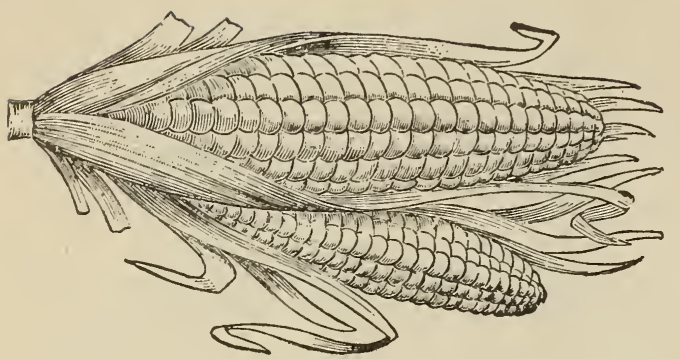

PEFP O'DAY NEW SWEFT CORN-Ten days earlier than any other; sweet, early, productive. You will not be disappointed in this New Sweet Corn. Recently introduced. Has pleased everyone who has tired it. For flavor, sweetness and productiveness it is ahead of any other early white sweet corn. It will prove a money maker for the market gardener, and a valuable addition to our list of corn for our short western summers. Pkt., 15c; 1b., 30c; 10 1bs., $\$ 1.50$

MAMMOTI WHITE CORY-A large and excellent early sort. Each stalk produces two or more handsome, twelve-rowed ears of large, white grain, of a quality superior to most early sorts.

Pkt. 10c; 1b., 15c; 10 to $25 \mathrm{lbs}$., $8 \mathrm{c}$ per 1b.

WHITE COB CORY-An improvement on the Red Cobbed Cory, as well as being equally early. The ears are larger, and it has the further advantage of having both a white cob and white grain. A splendid market garden variety, and excellent for the table.

Pkt. 10c; 1b., 15c; 10 to 25 1bs., 8c per 1b.

FARIY IINNESOTA-One of the earliest kinds of sweet corn. The ears are of the best quality; it is very productive. A popular early variety.

Pkt. 10c; 1b., 15c; 10 to 25 1bs., 8c per 1b.

CROSBY'S EARIY-An early kind, producing well-filled ears of ten to twelve rows. It is remarkably sweet and tender, and considered by many superior to most other kinds.

Pkt. 10c; 1b., 15c; 10 to 25 Ibs., 8c per 1b.

EARIY SWEET, or SUGAR-Excellent for general crop. Medium early, remaining in condition

for the table a long time, tender and sweet.

PERRY'S HYBRID-A new variety; stalk of medium height. The ears are large, and grow low on the stalk. Kernels large, very white, tender and sweet.

Pkt. 10c; 1b., 15c; 10 to 25 Ibs., 8c per Ib.

EARIY MAMMOTH-Produces the largest ears of any variety, which are filled to the tip with large, full kernels, sweet, tender and delicious. The most popular variety for canning, also good for market or home use. The leading variety for a large and certain crop.

Pkt. 10c; 1b., 15c; 10 to 25 1bs., 8c per 1b.

STOWEII'S EVERGREFN - Remarkable for remaining a long time in a fresh condition, suitable for the table. Hardy and productive, tender and sugary, and the best late variety for general use.

Pkt. 10c; 1b., 15c; 10 to 25 1bs., 8c per 1b.

EARIY EVERGREFN-An improvement on Stowell's; similar in appearance and general character but a week or ten days earlier, and remaining fit for use somewhat later than that wellknown sort; equal to Stowell's in all other respects.

Pkt., 10c; 1b., 15c; 10 to 25 1bs., 9c per 1b.

BIACK MIXXICAN-One of the sweetest and best for the table. It is remarkably productive, and well suited to a warm climate. It is white and beautiful when in condition for coolking, but the kernels are bluish-black when ripe. Said to be less subject to the attacks of wornis than other sweet kinds.

Pkt. 10c; 1b., 15c; 10 to 25 Ibs., 8c per 1b.
COUNTRY GENTIFMAN-A large-eared, late variety of sweet corn, of delicious quality.

Pkt. 10c; 1b., 15c; 10 to $25 \mathrm{lbs}$, 8c per 1b.

EXTRA FARIY ADAMS-A very early variety. not strictly a sweet corn, but white and tender, and extensively used for the table.

Pkt. 10c; 1b., 15c; 10 to 25 1bs., 8c per 1b.

COMMON SWrrT-Used for general field crop for fodder. Sometimes sown thinly broadcast, but usually planted in hills or drills. Write for price.

\section{Field Corn}

Corn is $10 \mathrm{c}$ a pound extra if sent by mail or express prepaid.

EARIY RED BIAZFD or KING PFIIIIP-An arly, hardy variety, enduring considerable cold. Stalks of medium height, having few suckers. The ears are long, eight rowed, and well filled. Kernels bright yellow at the base, shading into red at the tips.

Pkt., 10c; 1b., 10c; 10 to $251 \mathrm{bs} ., 6 \mathrm{c}$ per $1 \mathrm{~b}$.

FARIY CANADA ON YEIIOW FIINT-A rapid-growing early yellow kind, and on this account much used for replanting. Superior where the seasons are short.

Pkt., 10c; 1b., 10c; 10 to 25 Ibs., 6c per 1b.

FARIY WIITE FIINT-A variety much used for making hominy. Productive, early, and of beautiful appearance.

Pkt., 10c; 1b., 10c; 10 to 25 Ibs., 6c per 1b.

IMPROVED IEAMING - YFIIOW DENT Ears nine to twelve inches long, eighteen to twenty rows; grains long and wedge shaped, indented at the outer end. Color rich yellow; small red cob. For general crop unsurpassed.

Pkt., 10c; 1b., 10c; 10 to 25 lbs., 6c per $1 \mathrm{~b}$.

PRIDE OF THE NORTH, YEIIOW DENT-A very early Dent variety, thriving where there are cold, short summers. Ears and kernels handsome yellow.

Pkt., 10c; 1b., 10c; 10 to 25 1bs., 6c per 1b.

CIAMPION WIITE PEARI-A large white late Dent variety, pearly white kernels.

Pkt., 10c; 1b., 10c; 10 to 25 lbs., 6c per Ib.

\section{Corn, Broom}

Requires similar soil and culture to corn, but, to obtain the best quality of brush, the land should be rich, and well and deeply cultivated. Usually planted in drills three and a half feet apart, and thinned to four to six inches apart in the row.

IMPROVED EVIRGREEN-An improvement on the common Evergreen. The result of many years' careful selection. Does not grow as tall as the old variety. The brush is fine, and of a light oreen tint.

Pkt., 10c; 1b., 15c; 10 to $251 \mathrm{bs.,} 9 \mathrm{c}$ per 1b.

\section{Cress}

The leaves, when young, have a warm, pungent taste, and are used as salad, either alone or mixed with other salad plants. The seed germinates quickly, and the plants grow rapidly. As they are milder and more tender when young, the seed should be sown at intervals of ten to fiften days. making the first sowing as soon as the ground can be prepared. May be cut several times.

CURIFD or PEPPER GRASS-The best garden variety.

Pkt., 5c; oz., 10c; 2 oz., 15c; $1 / 4$ 1b., 20c; 1b., 50c

\section{Cress, Water}

A delicate, pungent salad plant, very agreeable alone or mixed with other salads. Entirely distinct from common cress, thriving only where its roots are submerged. Sow the seeds thinly along the banks of any shallow stream, early in spring. It will increase rapidly, if the conditions are favorable, and repappear every spring, with no further attention, being a hardy acquatic plant.

Pkt., 5c; oz.. 35c; 2 oz., 60c; $1 / 4$ Ib., $\$ 1.00$ 


\section{CUCUMBER}

imbers need a warm, sandy soil, and should planted in open ground until the weather dind warm, as they will not thrive until a is thoroughly warmed. Plant in hills the strongest plants, after danger from passed. Sprinkle the young plants with plaster, or air-slaked lime, to protect

EARIY or PEERLESS WHTTE SPINE-Even In both ends, and uniform in size and almost universally grown for the pickle Sall Francisco. Also a fine market

Pkt., 5c; oz., 20c; 2 oz., 30c; $1 / 4$ 1b., 35c; 1b., $\$ 1.00$ EXTRA IONG OT EVERGREEN WHTE SPINE-IIs the characteristic IVhite spine qualities, but is longer than some other varieties, with smoother skin. A favorite early sort for forcins. Plt., 5c; oz., 20c; 2 oz., 30c; $1 / 4$ 1b., 35c; 1b., $\$ 1.00$

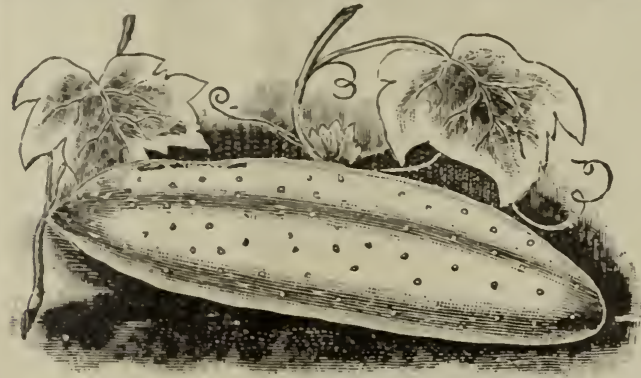

EARLY SHORT GREEN OT EARIY FRAMEA vigorous and productive variety, producing fruit of medium size and regular form; flesh crisp and tender; excellent for the table, or for pickling, while small.

Pkt., 5c; oz., 20c; 2 oz., 30c; 1/4 1b., 35c; 1b., $\$ 1.00$ COOL AND CRISP-Related to White Spine, but longer and more pointed at the ends. Especially tender and crisp, and a favorite for the table.

Plt., 5c; oz., 25c; 2 oz., 35c; 1/4 1b., 35c; 1b., \$1.00 CUMBERIAND-A new variety, combining the good points of its parents,-Parisian Pickling and Early White Spine. Vine strong and prolific of large and excellent fruit.

Pkt., 5c; 0z., 25c; 2 oz., 35c; 1/4 1b., 60c; lb., \$2.00 GREEN PROLIFIC or BOSTON PICKIING-A prolific bearer, fruit of medium size, rather pointed at the ends, bright green, and of good quality, especially for pickling.

Pkt., 5c; oz., 20c; 2 oz., 30c; $1 / 4$ 1b., 35c; 1b., $\$ 1.00$ EARIY CIUSTER-A productive early kind. The fruit, which is not large, is borne in clusters, and is crisp and of good flavor.

Pkt., 5c; oz., 20c; 2 oz., 30c; $1 / 4$ lb., 35c; 1b., $\$ 1.00$ EXTRA IONG GREEN-Another good variety, tender and crisp; green, long and slim.

Pkt., 5c; Oz., 20c; 2 oz., 30c; 1/4 1b., 35c; 1b., $\$ 1.00$ SMAII GHERKIN-A distinct variety, not trictly a cucumber; fruit very short, but rather thick; used only for pickling.

Pkt. $5 \mathrm{c}$; oz., 25c; 2 oz., 35c; $1 / 4$ 1b., 60c; 1b., $\$ 2.00$ JAPANESE CIIMBING-A sort of pole cucumber, its name being due to its origin and its tendency to climb and bear its fruit up from the ground, if afforded support; fruit large and thick. Pkt., 5c.

\section{EGG PLANT}

The egg plant, though not universally grown, is fast winning its way to more general use, ana, properly served, is a most excellent dish. It will are obtained in a deep, rich, warm loam. The seed germinates slowly, and should be started in a hotbed, or well-protected, warm place, kept very moist. Do not transplant till the weather is settled and the ground thoroughly warm. It thrives with the same treatment as that given the to-

EARIY IONG PURPLE-Fruit rather long, usually largest at the blossom end; a hardy kind, productive, and of good quality. $1 \mathrm{~b}, 55 \mathrm{c}$; $1 \mathrm{~b}, \mathrm{I}, 75$ FARIY ROUND PURPIE-Fruit large, oval sirable for the family or market garden.

Pkt., 5c; oz., 25c; 2 oz., 35c; 1/4 lb., 65c; 1b., \$2.25

IARGE NEW YORK Improved Purple-Similar in form to Early round Purple, but a little later. Fruit large. of good quality, and produced Pkt., 5c; oz., 35c; 2 oz., 60c; 1/4 1b., 90c; 1b., $\$ 3.00$ BLACK PEKIN-Oval round, of medium size, ery dark glossy and handsome. Flesh delicate and excellent. Prized for the family garden.

Pkt., 5c; oz., 25c; 2 oz., 45c; $1 / 4$ lb., 75c; 1b., \$2.50

\section{ENDIVE}

The garden endive is much cultivated in Europe for winter salad. It is bitter until properly blanched, when it makes a fine salad, and is spring, or later for winter use, in drills a foot apart. Thin from ten to twelve inches apart. Keep the ground clear of weeds until the plant has attained its full size, when it is blanched by in the light and air are thus excluded from the inner leaves, which will be blanched in two or three weeks.

GREEN CURLED-The hardiest variety; dark GRen Pkt., 5c; oz., 15c; 2 oz., 25c; $1 / 4$ lb., 40c; 1b., $\$ 1.25$ WHITE CURIED-Coarser and less tender than Green Curled, but very attractive on account of its color, even the outside leaves being very light .

Pkt., 5c; oz., 15c; 2 oz., 25c; 1/4 1b., 40c; 1b., \$1.25 BROAD-IEAVED BATAVIAN SCAROLIE Has broad, thick leaves, which form a large, loose head. Fine for soups and stews. If blanched, by tying the outer leaves together, it makes an excellent table salad.

Pkt., 5c; Oz., 15c; 2 oz., 25c; 1/4 lb., 40c; 1b., \$1.25

\section{KALE OR BORECOLE}

$\mathrm{Kale}$, or Borecole, is a kind of cabbage that does not form a close and solid head, but a cluster of beautifully curled or wrinkled leaves, that are tender and of excellent flavor. It requires the same treatment as cabbage, and is very hardy, eing improved by frost.

TAIL GREEN CURIED SCOTCH-Produces an abundance of dark green, curled leaves. Very hardy. The leading variety.

Pkt., 5c; oz., 15c; 2 oz., 20 ; 1/4 1b., 30c; 1b., $\$ 1.00$ DWARF GREEN CURIED OT GERMAN GREENS-A dwarf variety finer and more compact than the Scotch. Can be sown in the fall, for use early in the spring.

Pkt., 5c; oz., 15c; 2 oz., 20c; $1 / 4$ lb., 30c; lb., $\$ 1.00$

DWART GERMAN PURPIE-A variety much prized by the Germans, and similar to German Greens, except that it has a deep purple tint. Very handsomely curled, and of good quality. Also hardy, and can remain in the garden all winter.

Pkt., 5c; oz., 15c; 2 oz., 20c; $1 / 4$ 1b., 30c; 1b., \$1.00

\section{KOHLRABI}

Kohlrabi is a vegetable partaking somewhat of the nature and flavor of both the cabbage and turnip. The stem, just above the ground, swells into a bulb resembling a turnip, which is the edible part. It should be cut for the table before it is fully grown, as it becomes tough and stringy if allowed to grow too long. Sow as soon as the ground can be prepared, in drills, the same as turnips. Thin to

EARLY WHITE VIENNA-Best table sort; pure white, medium-sized bulbs. 


\section{LEEK}

The leek belongs to the onion family, and, on account of being milder and less pronounced in flavor, is preferred by many for soups and stews. It is very hardy, and may be sown as soon as the ground can be prepared, in drills fifteen inches apart, covering one inch deep.

IARGE ROUEN, or AMERICAN FIAG-A large, strong-growing variety, of good quality, and hardy. The leading market kind.

Pkt., 5c; oz., 15c; 2 oz., 25c; 1/4 1b., 40c; 1b., \$1.25 MONSTROUS CARENTON-Rather larger than the Flag, and very tender and mild, on account of its rapid growth

Pkt., 5c; oz., 20c; 2 oz., 30c; 1/4 1b., 50c; 1b., $\$ 1.50$

\section{LETTUCE}

Lettuce will thrive in any good garden soil, and requires so little care that all who have the ground at their disposal should raise enough for their own use, and especially as the quality depends almost entirely on its crisp freshness. Where severe frosts prevail, it may be sown under cover in fall, and transplanted, and in milder localities as soon as the soil can be thoroughly prepared, in open ground, in drills fifteen inches apart. Thin out by using the larger plants as soon as of sufficient size, and so continue until the crop is exhausted. Keep the ground moist and loose, and the bed free from weeds.

EARIY TENNIS BAII, SEED BIACK-The plant is small, of rapid growth, and should be used as soon as large enough, as it quickly runs to seed. Solid head, leaves dark green, thick, and crisp. One of the best for growing under cover and for forcing.

Pkt., 5c; oz., 15c; 2 oz., 20c; 1/4 1b., 30c; 1b., \$1.00

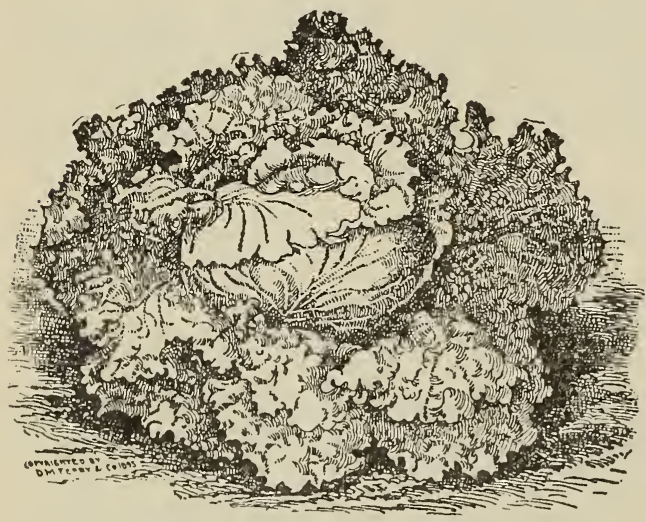

BIACK-SEFDED SIMFSON'S-An excellent variety, and not as generally grown as its merits justify. It has all the good qualitites of Simpson's Early Curled. which it resembles, but is larger, lighter colored, and the leaves are less curled. It is one of the tenderest and sweetest, and remains so longer than most other kinds.

Pkt., 5c; oz., 10c; 2 oz., 15c; 1/4 1b., 25c; 1b., 75c

EARIY PRIZE HEAD, SEED WHITE-An early variety, not strictly forming a head, but a dense cluster of beautifully bronzed leaves, that are remarkably tender and sweet. Slow to run to seed, remaining long in condition for the table. Too delicate and tender for market gardening. but for family use, where it can be taken from the garden and immediate prepared for the table, it has no superior.

Pkt., 5c; oz., 10c; 2 oz., 15c; 1/4 1b., 25c; 1b., $75 c$

BIG BOSTON, SEED WHITE-A splendid winter variety in the South, and a large header; in the North a favorite forcing sort; leaves broad, smooth and tender. Its all-around excellence makes it a popular market variety.

Pkt., 5c; oz., 10c; 2 oz., 20c; 1/4 lb., 30c; 1b., \$1.00

SIMPSON'S FARIY CURIED, SEED WHITE -A leading market variety, used for very early planting and forcing. Forms a dense mass of finely curled and wrinkled leaves that are excellent and tender, and do not wilt readily.

Pkt., 5c; oz., 10c; 2 oz., 15c; 1/4 1b., 25c; 1b., 75c

SAN FRANCISCO MARKET, BIACK SEEDLarge, solid heads, bearing transportation well. Color beautiful medium light green; opens very white; tender and sweet. Undoubtedly a desirable acquisition as a market or family variety.

Pkt., 5c; oz., 15c; 2 oz., 20c; 1/4 1b., 30c; 1b., $\$ 1.00$

IARGE HANSON, SEED WHITE-This variety forms the most perfect heads of any. They are small, creamy white inside, and very tender, but should be used young, as they are liable to become bitter with age, or when they mature slowly. An excellent market kind, longer in running. to seed than any other.

Pkt., 5c; oz., 10c; 2 oz., 15c; 1/4 1b., 20c; 1b., 75c

IARGE DRUMHEAD, SEED WHITE-A leading market variety, and one of the largest heacing kinds, but the heads are not as solid as the Hanson or Deacon. It is slow running to seed, white, crisp and tender.

Pkt., 5c; oz., 10c; 2 oz., 15c; 1/4 1b., 25c; 1b., $75 c$

DENVER MARKET, SEED WHITE-The chief characteristic of this sort is that it has a beautifully curled savoy-like leaf, which gives it a very attractive appearance. It is also a Drumhead variety of very excellent quality, and extremely early. Sure to enjoy great popularity.

Plet., 5c; oz., 10c; 2 oz., 15c; 1/4 1b., 25c; 1b., 80c

GRAND RAPIDS, SEED BIACK-A large, attractive variety that matures early, a favorite with market gardeners for keeping in good condition longer after being cut than other sorts. Fine for green-house forcing.

Pkt., 5c; oz., 15c; 2 oz., 20c; 1/4 1b., 30c; 1b., \$1.00

WHIT PARIS COS Or ROMAINE, SEED WHITE-A distinct variety, forming oblong, upright heads, largest near the top. It is hardy, tender and crisp, and does not run to seed as quickly as some other Cas varieties, of which it is generally considered the best.

Pkt., 5c; oz., 10c; 2 oz., 15c; 1/4 1b., 25c; 1b., 80c 


\section{MELON, MUSK}

The melon is so universally grown, and so justopular, that it requires but little description. emitropical habit it comes to its full state of perfection in the rich sandy loams and warm alleys of the Pacific Slope and Southhern States. nder the above head all the green and yellowleshed Cantaloupes and Nutmeg Melons are

\section{Green-Fleshed Kinds}

EARIY JENNY IIND-A small, very early vaflattened at the ends, medium to small in The flesh is very sweet and juicy.

Pkt., 5c; oz., 15c; 2 oz., 25c; 1/4 1b., 40c; 1b., $\$ 1.20$ SMAII GREEN NUTMEG-A variety resem-

ling the Jenny Lind, and ripening nearly as ear-

The flesh is fine and very sweet. Superior for the early market or family garden, and a faPkt., 5c; oz., $15 c$; 2 oz., 25c; $1 / 4$ lb., 40 ; 1b., $\$ 1.20$

EXTRA EARIY HACKENSACK-A variation rom the last preceding, much favored by some; coarser netting and deeper ribs. Green flesh, sweet and juicy

EARIY BALTIMORE or ACME-A good-sized oval-round very desirable variety. The flesh is markets of the Eastern and Southern cities.

Plt., 5c; oz., 15c; 2 oz., 25c; $1 / 4$ 1b., 40c; 1b., $\$ 1.20$

IARGE NETTED CANTALOUPE-A rather large variety, medium early, of excellent quality desirable either for the family or market garden.
Pkt., 5c; oz., 15c; 2 oz., 25c; 1/4 1b., 40c; 1b., $\$ 1.20$

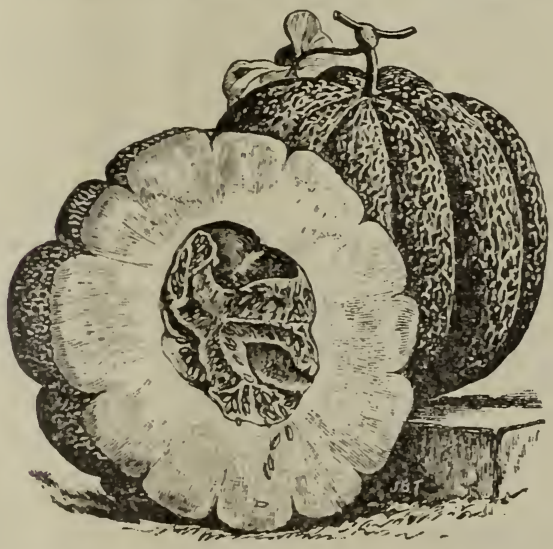

NETTED GEM, or ROCKY FORD-A kind that has attained great popularity; on the small or basket melon order. Shape oval, very sweet, with exceedingly smooth-grained flesh. Slightly ribbed and covered with coarse netting.

Pkt., 5c; oz., 15cc; 2 oz., 20c; $1 / 4$ lb., 30c; 1b., $\$ 1.00$

IARGE GREEN NUTMEG-An improved variety of the old Green Nutmeg; has all its good qualities, combined with larger size, thicker and firmer flesh, and a more vigorous vine. About as early as the Large Netted Cantaloupe, which it resembles.

Pkt., 5c; oz., 15c; 2 oz., 25c; $1 / 4$ 1b., 40c; lb., $\$ 1.20$

IARGE MONTREAI-A large variety, ripening medium early; not deeply ribbed nor netted. The flesh is thick, firm and excellent; keeps well after taken from the vine; a good market kind.

Pkt., 5c; oz. . 15c; 2 oz., 25c; $1 / 4$ 1b., 40c; ib., $\$ 1.20$

HACKENSACK-A large, prolific variety, growing in favor: oval round, flattened at the ends, deeply ribbed and netted. The flesh is delicious, juicy and sweet. A good market kind.

Plkt., 5c; oz. 15c: 2 oz., $25 \mathrm{c}$; $1 / 4$ lb., $40 \mathrm{c}$; 1b., $\$ 1.20$

BAY VIEW-Fully as large as the Casaba, bu a handsomer melon, ripening earlier. The flesh is rich and melting, and will ripen well if taken from the vine a little green, which makes it one of the best market kinds.

Pkt., 5c; Oz.. 15c; 2 oz., 25c; $1 / 4$ 1b., 40c; 1b., $\$ 1.20$

Yellow or Orange-Fleshed Varieties

EARIY YEIIOW CANTAIOUPE-Similar to the Surprise, but usually larger, not ripening quite as early, and deeper ribbed. Good for the family or market garden.

Pkt., 5c; oz., 15c; 2 oz., 25c; $1 / 4$ 1b., 40c; 1b., $\$ 1.20$

PETOSKEY or PAUI ROSE-A sweet, yellowfleshed melon, somewhat resembling the Netted Gem in size and appearance; firm, oval in form, of fine quality and flavor.

Pkt., 5c; oz. . 15c; 2 oz., 25c; $1 / 4$ 1b., 40c

OSAGE or MIILER'S CREAM-Nedium size, shallow ribs, and thin netting; color deep green; flesh a decided salmon in color, and good clear down to the rind.

Pkt., 5c; oz., 15c; 2 oz., 25c; 1/4 1b., 40c; 1b., $\$ 1.20$

FMERAID GEM-Medium size, rather deeply ribbed, not netted, but smooth and handsome. The flesh is as thick as the Christiana, but pronounced sweeter and more delicate flavored. It ripens ear$1 \mathrm{y}$, and is very prolific.

Pkt., 5c; oz. . 15c; 2 oz., 25c; $1 / 4$ 1b., 40c; 1b., $\$ 1.20$

\section{MELON, WATER}

The watermelon, in its origin and habits, is similar to the muskmelon, and should receive the same cultivation and treatment, except that the hills should be farther apart.

PHINNEY'S EARLY-A valuable early kind, producing an abundant crop. Rather long, rounded at the ends. It is mottled with stripes of dark and light green; thin, firm rind; flesh of excellent grain and quality.

Pkt., 5c; oz. 10c; 2 oz., 15c; 1/4 1b., 20c; 1b., 50c ICE-CREAM or PEERIESS-Rind pale green, mottled, nearly round; flesh bright scarlet, very sweet and delicious; excellent for the family garden. A standard variety.

Pkt., 5c; oz. 10c; 2 oz., 15c; 1/4 1b., 20c; 1b., $50 c$ IODI or SAN JOAQUIN-A great producer, and very popular in California. Cylindrical shape uniform medium size; rind yellowish green, thin and firm; seeds large, ashy white; flesh dark pink, firm, ripening well to the core, sweet and delicious. It holds its place in the market after being tested for many years.

Pkt., 5c; oz. 10c; 2 oz., 15c; $1 / 4$ 1b., 20c; 1b., $50 c$ FIORIDA FAVORITE-Large and long, mottled dark green, with lighter stripes. Rind firm flesh deep red. Popular in the South generally.

Pkt., 5c; oz., 10c; 2 oz., 15c; $1 / 4$ 1b., 20c; 1b., 50c SWEETHEART-Takes almost first place as favorite in the East. Large, handsome, and a good shipper. In color, bright mottled green; in form, almost oblong, its thickness about twothirds its length. Flesh bright red, firm, crisp, and sweet.

Plt., 5c; oz., 10c; 2 oz., 15c; 1/4 1b., 20c; 1b., 50c KOIB'S GEMI-Very large, oval shaped, deeply mottled; vines vigorous and remarkably productive. Flesh bright scarlet, solid, and sweet. Rind thin, but very firm. Can be safely shipped long distances.

Pkt., 5c; oz. 10c; 2 oz., 15c; 1/4 1b., 20c; 1b., 50c MOUNTAIN SWEET-Medium size. long. rather square at the ends, sometimes slightly curved; rind dark green; flesh deep red and firm, but ripening well to the core. A good market kind.

Pkt., 5c; oz. 10c; 2 oz., 15c; 1/4 1b., 20c; 1b., $50 c$ GIPSY or SOUTHERN RATTLESNAKEAbove the average in size, a strong grower and good bearer, mottled and striped dark and light green; long, rather square at the ends; firm rind; flesh deep scarlet, of excellent grain and quality ships well, and is a good market or family garden ariety

Pkt., 5c; oz. 10c; 2 oz., 15c; $1 / 4$ 1b., 20c; 1b., 50c 


\section{MELON, WATER-Continued}

DrxIE-This is a new melon of excellent quality. Flesh red and tender, ripening evenly and all good; size medium to large; skin dark green, beautifully mottled, and very attractive. A heavy cropper, and fine for shipping or home use.

Pkt., 5c; oz., 10c; 2 oz., 15c; 1/4 1b., 20c; 1b., 50c

KLECKLEY'S SWEETS or MONTE CRISTO -A strong-growing and prolific variety; medium size; skin mottled in dark and light green stripes; flesh red, tender and sweet. Not firm enough for shipping long distances.

Pkt., 5c; oz., 10c; 2 oz., 15c; 1/4 1b., 20c; 1b., 50c

DARK ICING or ICE RIND-A distinct variety, resembling in size and shape the Peerless $u$ Ice-cream, but is lighter in color, and faintly mottled. The rind is not thick, but rather firm. The flesh is remarkably juicy, sweet, and delicious.

Pkt., 5c; oz., 10c; 2 oz., 15c; 1/4 1b., 20c; 1b., 50c
IIGHT ICING OI JORDAN'S GRAY MONARCH -A very large variety; light green in color; flesh light red, tender, and sweet. Considered by many the best melon grown.

Pkt., 5c; oz.. 10c; 2 oz., 15c; $1 / 4$ 1b., 20c; 1b., 50c

CUBAN QUEEN-The largest variety known, having attained a weight of one hundred pounds in California. Oval round, dark and light green mottled stripes of pronounced shade; vines not large, but vigirous; flesh deep scarlet and firm, ripening well to the core. A good shipper for so large a melon.

Plkt., 5c; 0z., 10c; 2 oz., 15c; 1/4 1b., 20c; 1b., 50c

BIACK SPANISF-A round melon of medium size; rind very dark green, thin, but firm; seeds black. The flesh is deep scarlet, firm, with no hard center. and is remarkably sweet and delicious. One of the best for the family garden; also much used for marketing.

Pkt., 5c; oz., 10c; 2 oz., 15c; $1 / 4$ 1b., 20c; 1b., 50c

\section{MUSHROOMS}

The mushroom is an edible fungus that does not produce seed, but is propagated from the white fibers, resembling roots, that spread from the base of the stool, termed spawn. It is grown in out-building's, cellars, caves, or wherever a uniform temperature of 60 degrees to 70 degrees can be maintained. Make beds of fermenting manure, which should be large and deep enough to acquire a heat of about 70 degrees. When at the proper temperature, insert bits of spawn at intervals. As soon as signs of growth appear, place two inches of soil over them, and cover all with straw. Water is used, if necessary, which should be warmed to the temperature of the bed. Mushrooms appear in six or eight weeks, and shoula be collected when at the proper size for the table. More complete directions are contained in each box.

French Mushroom Spawn is supplied in boxes and English in bricks.

ENGIISH-1-1b. bricks, each, 35c, prepaid.

\section{MUSTARD}

A hardy, pungent plant, highly esteemed by fall, and produces enormous bunches. Excellent many as an appetizing salad, for which purpose for salad, and very generally used for greens, it should be cut when two or three inches high. It is also used, when larger, as greens. The seed has an extensive sale, and is used in its natural state and prepared. It should be sown in rich, mellow soil, as early as the ground can be well prepared, in drills fifteen inches apart.

SOUTHERN GIANT CURIFD-Highly esteemed in the South, where is is sown in the for which it is largely cultivated.

Pkt., 5c; oz., 10c; 2 oz., 15c; 1/4 1b., 25c; 1b., 80c YELLOW CAIIFORNIA Or WHITE FNGIISH -Leaves mild, tender when young, and generally preferred for salad. The seed, which is light yellow, is largely used with pickles and in salads. Pkt., 5c; 0z., 10c; 2 oz., 10c; 1/4 1b., 15c; 1b., 30c

\section{NASTURTIUM}

\section{(Tropoeolum Majus)}

The nasturtium is very popular as an orna- or other convenient support, where it will grow mental plant, and also for the table. The leaves when young are used as salad, and also in connection with the flowers for garnishing, and the seeds for capers and pickles, for which purpose they should be gathered while green and tender. It is hardy, and may be planted as soon as the ground can be prepared. beside a fence, trellis,

\section{rapidly and climb high.}

TAII MIXED GARDEN-Mostly used, as they produce the largest seeds. 'They have also very handsome foliage and beautiful flowers. For Lobbianums and fine Dwarf varieties, see Flower List.

Pkt., 5c; 0z., 10c; 2 oz., 15c; 1/4 1b., 25c; 1b., 80c

\section{OKRA OR GUMBO}

Extensively grown in the Southern States and California, where it may always be seen in the markets, either green or dried. Its peculiarly ribbed seed pods are much used in soups, and may be stewed and served as asparagus.
DWARF-Best for general crop. The plant is dwarf, but the pods are as long as the largergrowing kinds, and are produced much more abundantly.

Pkt., 5c; oz., 10c; 2 oz., 15c; $1 / 4$ 1b., 20c; 1b., 60c 
Onions can be sucessfully grown on almost
any soil that will produce a full crop of corn;
land that has been cultivated with hoed crops
and kept free from weeds and well manured fo
two years previous is very much preferred.
Manure evenly at the rate of about fifty cart-
loads to the acre; the manure must be thor-
oughly mixed with the soll and all well pulver-
ized. Sow, as soon as the ground can be pre-
pared, about one-half inch deep, and lieep per-
fectly free from weeds.
Crops very short and prices subject to change any time.

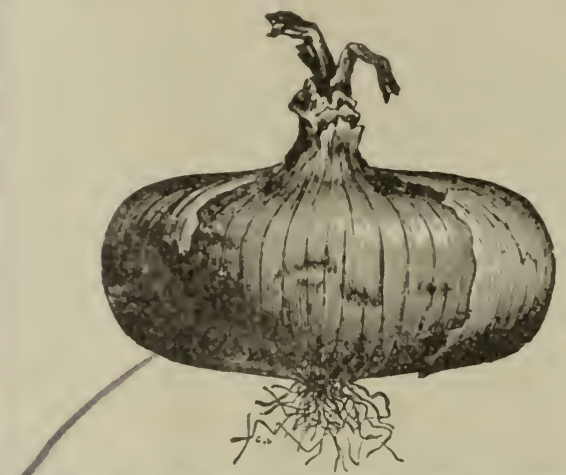

EXTRA FARIY IARGE RED GLOBE-A large, early, rapid-growing kind. Skin deep purplish red; flesh white, mild, and unusually sweet. Best for early use, as it does not keep long. If the old ripe onions of this variety are set out in the spring, the old onion will run up to seea nions will grow from it, and quite a crop can be produced in this way, with very little trouble. Plet., 5c; oz., 25c; 2 oz., 45c; $1 / 4$ lb., 75c; 1b., $\$ 2.00$ EXTRA EARIY RED FIAT-Deep red in olor; resembles the Red Wethersfield, except desifable for early market.

Pk\%, 5c; oz., 25c; 2 oz., 45c; $1 / 4$ lb., 75c; 1b., \$2.00 AARGE RED WETHERSFIELD-A standard ariety, one of the most productive kinds, even on poor soil. Its good keeping qualities render it one of the best for shipping. Large, slightly sfonger than the Early Red Globe, but rich and kt., 5c; oz., 25c; 2 oz., 45c; $1 / 4$ 1b., 75c; 1b., $\$ 2.50$ GIANT WHTE ITALIAN TRIPOII-Resembles somewhat the American White Portugal, but is much larger. It is flat, pure white, mild, and of good flavor.

Pkt., 5c; oz., 25c; 2 oz., 45c; $1 / 4$ lb., 80c; 1b., $\$ 2.50$ AUSTRAIIAN BROWN-Beautiful yellowish n in color, slightly globular in shape, ot good size, and mild flavor. Decidedly the hardest most solid, and longest-keeping onion yet offered to the public.

Fift., 5c; oz., 25c; 2 oz., 45c; 1/4 lb., 80c; 1b., $\$ 2.50$ YELLOW GLOBE DANVERS-A uniformly llobe-shaped, handsome variety; bright color Pkt 5c; oz., 25c; 2 oz., 45c; $1 / 4$ 1b., 80c; 1b., \$2.50 IFLIOW DANVERS-The leading large yelkind, round, slightly flattened, flesh fine grained, rather mild, very rich and sweet. Ont of the best keepers and shippers, and one of the plost productive kinds.

Pkt. 5c; oz., 25c; 2 oz., 45c; $1 / 4$ lb., 80c; lb., $\$ 2.50$ SPANISH KING ON PRIZE TAKER-An immense light golden-yellow onion, originating in Spain: recently sprung into great popularity; ver attractive

l., $5 c$; oz, 25c; 2 oz., $40 c$; $1 / 4$ 1b., 80c; 1b., $\$ 2.50$ WHITE PORTUGAI OT, AMERICAN SIIVER skIN-A large, flat, silver-white onion, mild in flavor, and very handsome. A great favorite for
Plol., 5c; oz., 35c; 2 oz., 65c; $1 / 4$ 1b., 80c; 1b., $\$ 2.50$ WHITE GIOBE-A handsome, white, globewaped variety; llesh fine, very white, rich and weet. It is also one of the best keepers' of the silyer-skinned kinds.

Plt., 5c; oz., 25c; 2 oz., 35c; $1 / 4$ lb., 60c; 1b., $\$ 2.00$ MAMMOTH SIIVER KING-An immense hite onion of mild flavor, very thick through, but inclined to be flat rather than globe shaped. P)t., 5c; oz., 35c; 2 oz., 65c; $1 / 4$ 1b., 80c; 1b., $\$ 2.50$ EI PASO or IARGE MEXICAN-One of the argest onions grown, frequently attaining a weight of three pounds or more. Color mostly white, but sometimes tinged with yellow and red. Fesh rather coarse, but of excellent flavor, mild rich, and sweet. Very popular in Mexico, re it is the leading variety grown.

P)t., 5c; oz., 25c; 2 oz., 45c; 1/4 1b., 75c; 1b., $\$ 2.75$ QUEEN-White, early, handsome, and a good keeper. If sown thick, produces small, very firm bulbs, the best of all for pickling; if given more room, matures an excellent onion, that will keep all winter.

Pkf., 5c; oz., 35c; 2 oz., 65c; 1/4 1b., \$1.00; 1b., \$3.00 AARIY BARIFTTA-Small white, said to be Pkt., 5c; oz., 35c; 2 oz., 65c; $1 / 4$ lb., $\$ 1.00$; 1b., \$3.00

\section{ONION SETS}

BOTTOM ONION SETS-Are grown from seed that has been sown too thick to attain a large size. The small onions thus obtained are planted out, and are ready in a short time to pull as green onions for the table or bunched for the market. If left to stand, they make ripe onions of the best quality, and come to maturity some six weeks earlier than a crop grown direct from the seed. Yellow sets are most in demand, but Red and White are used to some extent. Sow forty to sixty pounds of black seed to the acre to raise Yellow, lb., 30c; 100 lbs., \$12, by freight, charges collect.

\section{PARSLEY}

Parsley is very generally used for garnishing, and seasoning soups and stews. It can be used fresh from the garden, or dried and rubbed into fine powder, when it can be bottled for winter use. It becomes finer and more beautifully curled if cut frequently. As the seed germinates slowly. it should be soaked a few hours in warm water. and sown in drills a foot apart and half an inch deep, as early in spring as possible. Thin to three or four inches apart. Thrives best in deep, rich soil.

MOSS CURIED or FERN IEAVED-A beautiful fern or moss-like variety. The best for garnishing.

kt., 5c; Oz., 10c; 2 oz., 15c; 1/4 1b., 20c; 1b., 50c

FINE TRIPIE CURIED-Fine for seasoning; also good for table decoration

Pkt., 5c; oz., 10c; 2 oz., 15c; $1 / 4$ Ib., 20c; 1b., 50c

\section{PARSNIP}

The parsnip is nutritious and wholesome, with a sugary sweetness peculiar to itself, and is superior both for the table and for stock feeding. It yields a large crop, and is said to be more valuable for dairy cows than either the carrot or turnip. As the seed germinates very slowly, sow as early in spring as possible, in drills fifteen inches apart, on deeply-cultivated, rich, loamy soil. Keep clear of weeds and thin to three or four inches apart. The roots are im-

IONG DUTCH SUGAR-A fine-flavored, standard variety. Long. large roots. Sweet and sugary.

Pkt., 5c; oz., 10c; 2 oz., 15c; 1/4 1b., 20c; 1b., 50c HOLIOW CROWR-Fine, smooth roots. The best for general use. Productive and excellent. Pkt., 5c; Oz., 10c; 2 oz., 15c; $1 / 4$ lb., 20 ; 1b., $50 c$ 
(When peas by the pound are wanted by mail or express, prepaid, remit 10 cents per pound extra for charges; 10, 25, and 100-1b. lots by freight, charges collect.)

While almost any soil will produce good peas, yet, like most other vegetables, they respond to liberal treatment and careful cultivation. Wellrotted stable manure and bone dust make excellent fertilizers for this crop. Deep plowing is of the greatest importance. For early peas, plant as soon as the ground can be worked, in light, welldrained soil and a sunny exposure. For the main crop a heavier soil may be selected. They are usually planted in double rows, about four feet apart, and three inches deep. Bush those that require it, when six inches high. The field cror may be sowed broadcast.

Our garden peas have been grown from selected seeds, are true to name, have been carefully hand picked, and are fit for gardeners' use at once. W€ ask our customers not to confound them with the common peas usually found in the market at a low price, which are only fit for field use or for feeding stock. Our list includes the best kinds and is sufficiently varied to meet the wants of all

\section{Extra Early Peas}

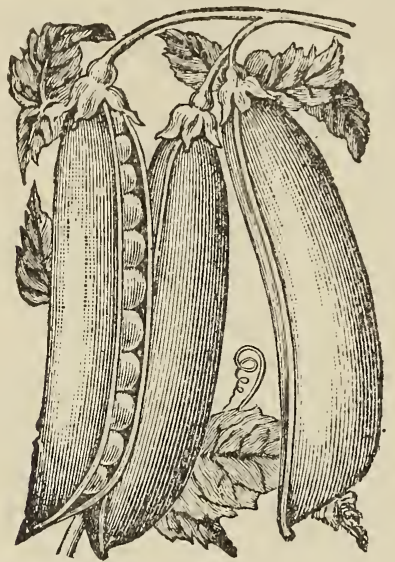

FIRST AND BEST-Unsurpassed for early and even ripening. One of the very best for market gardeners, as the whole crop ripens within a few days, so that the ground may be cleared and another crop planted. About forty-five days is the average from planting until the whole crop is ready for market.

Pkt., 10c; 1b., 15c; 10 to 25 1bs., 8c per 1b.

AIASKA or FARIIEST OI AII-Earliest and best of all the blue, smooth varieties, coming to two and a half feet.

Pkt., 10c; 1b., 15c; 10 to 25 Ibs., 8c per 1b.

AMIRICAN WONDIR-One of the earliest sweet wrinkled kinds in cultivation; constantly coming into more general use. It is a wonderlarge and well filled. The pea is rather above the average in size, and very sweet and delicious. Height nine inches.

Pkt., 10c; 1b., 15c; larger quantities, write for

\section{Extra Early Varieties}

When peas by the pound are wanted by mail or express prepaid, remit 10 cents per pound extra for charges; 10,25 and 100 pound lots by freight, charges collect.

NOTT'S EXCETSIOR-One of the best Extra Early sweet wrinkled kinds. Resembles the American wonder, but the plants are larger and more vigorous; quite distinct from that or the Premium Gem.

Pkt., 10c; 1b., 15c; larger quantities, write for price.

McIEAN'S ITTTIE GEIM-A sweet, wrinkled pea, coming in a little later than the American Wonder; grows taller, and continues in bearing longer. The quality of the pea is very superior. Height fifteen inches.

Pkt., 10c; 1b., 15c; 10 to 25 1bs., 10c per 1b.

PREMIUM GEM-One of the earliest dwarf, green, wrinkled varieties. Prolific and of fine quality. Similar to the Little Gem.

Pkt., 10c; 1b., 15c; 10 to 25 lbs., 10c per $1 \mathrm{~b}$.

DWARE TELEPFONE-Very similar to the large or tall Telephone, growing about $11 / 2$ feet tall and quite early. A favorite sort with our market gardeners

Pkt., 10c; 1b., 15c; 10 to 25 1bs., 10c per 1b.

GRADUS-This valuable creation fills a place not heretofore occupied by any kind of peas, es pecailly for the home garden. It is extra early, producing immense pods that are filled with large sweet, wrinkled, dark green peas of finest quality. Every family and gardener should try it.

Pkt., 10c; 1b., 15c; 10 to $25 \mathrm{lbs} ., 12 \frac{1}{2} \mathrm{c}$ per $1 \mathrm{~b}$.

\section{Second Early Peas}

MCIEAN'S ADVANCER-A green, wrinkleõ sort, bearing fine, broad pods. Comes in next after the Gems. Popular market kind, and used extensively by canners. Height two and a half feet.

Pkt. 10c; 1b., 15c; 10 to $251 \mathrm{bs} ., 9 \mathrm{c}$ per $1 \mathrm{~b}$.

ABUNDANCE-Medium early, very sweet and wrinkled, peas fair size, pods well filled. Next in earliness to Advancer. Height one and a half to two feet.

Pkt., 10c; 1b., 15c; 10 to $251 \mathrm{bs} ., 9 \mathrm{c}$ per 1b.

\section{HORSFORD'S MARKET GARDEN-Anothe} favorite among the sweet wrinkled varieties Vines medium height, very prolific; peas medium size, dark green, fine flavored. Excellent for can-

Pkt., 10c; 1b., 15c; 10 to 25 lbs., 9c per 1b.

EVIRBEARING-Large, sweet, wrinkled, medium early, large pods, cooks quickly, perhaps not quite as sugary as some others, but very desirable. Height one and a half to two feet.

Ekt., 10c; 1b., 15c; 10 to 25 1bs., 8c per 1b.

TEIEPHONE-This variety has now come intc general use, and is acknowledged to be of great merit. Peas large wrinkled, very sweet; pods enormous and well filled. Height four feet medium late.

Pkt., 10c; 1b., 15c; 10 to 25 1bs., 9c per 1b.

\section{General Crop-Late Peas}

YORKSHIRE HIRO-One of the largest sweet wrinkled kinds; vines strong and spreading; pods of good size and well filled; much in use, and has enjoyed a long popularity; medium late; bears a long time; height two and a half feet.

Pkt., 10c; 1b., 10c; 10 to 25 1bs., $7 \mathrm{c}$ per 1b.; $10 \mathrm{C}$ 1 bs., $\$ 5.00$.

STRATAGEM-A sweet, wrinkled variety, in. troduced from England. Vines not large, but of vigorous growth, producing a heavy crop; beauti ful, long pods, well filled with large peas of gooc quality; two feet.

Pkt., 10c; 1b., 15c; 10 to 25 1bs., 9c per 1b.

CHAMIPION OF ENGIAND-The leading late sweet. wrinkled pea. Vines large, luxuriant, anc very prolific. For either family use or the marker garden it has no superior; five feet.

Pkt., 10c; 1b., 15c; 10 to 25 1bs., 8c per $1 \mathrm{~b}$.

IARGE WHITE MARROWFAT-A leading kind for the main crop; of vigorous growth; pods long, and well filled with large, smooth peas, thai are of a creamy color, and very handsome wher ripe; four feet

Pkt., 10c; 1b., 10c; 10 to 25 1bs., 7c per 1b. 


\section{GENERAL CROP-LATE PEAS-Continued}

BIACK-EYED MAREOWFAT-Similar to the hite Marrowiat, but the vine is smaller, and
e pea has a black eye. Yields lieitily; three

Pkt., 10c; 1b., 10c; 10 to 25 1bs., 7c per $1 b$.

Edible Podded Peas

TAII SUGAR, BROWN SEEDED-A varlety of pea of which the pod has not the tough lining common to other varieties, therefore pods can be cooked and eaten same as string beans. This variety grows about four feet high; pods large, tender, sweet, and succulent.

Plat. 10c; 1b., 20c.

\section{PEPPER}

Sow the seeds early in hotheds, or later, when weather becomes warm, in open bods; when llow soil, in rows eighteen inches apart and foot apart in the row. Gunno and lien manure excellent fertilizers, and will greatly increase yield.

IARGE BEII or BULI NOSE-A large, mild, ick-fleshed vitriety. One of the best for stuffed kt., 5c; oz., 20c; 2 oz., 35c; $1+1$ b., 60c; 1b., $\$ 2.00$ SWEET SPANISH or MOUNTAIN-Similar to Large liell, hut usually larger. Excellent for kling and stutting.

kt., $5 \mathrm{c} ;$ oz., 20c; 2 oz., 35c; 1 is 1b., 60c; 1b., \$2.00 SQUASH Or TOMATO SHAPED-Pods short, ick, and ribbed at the point. They are very oductive, flesly and mild, and excellent for ckling.

kt., $5 \mathrm{c}$; 0z., 20c; 2 oz., 35c; $1 / 4$ 1b., 60c; 1b., $\$ 2.00$ CBuII-Produces small, pointed pods, that are brilliant scarlet, and very pungent when ripo. sed largely in the manufacture of pepper sauce. Pkt., 5c; Oz., 25c; 2 oz., 45c; $1 / 4$ 1b., 80c; 1b., $\$ 2.50$

RED CHERRY-The pods are small, round, clossy scarlet, and very handsome when ripe. Fixcellent for mixing with pickles.

Plat., 5c; 0z., 20c; 2 oz., 35c; 1/4 1b., 60c; 1b., $\$ 2.00$

IONG IARGE RED-This kind is planted to roduce the article known as "Dried Chili," constantly found in the California and Mexican markets. It is large at the stem, tapering to a point at the tip, measuring three to five inches in length. Seeds and pods very pungent. Esteemed Pkt., 5c; Oz., 20c; 2 oz., 35c; $1 / 4$ 1b., 60c; 1b., \$2.00

IONG RED CAYENNE-Brilliant, coral-red pods, three or four inches lorg, and a prolific bearer. Very pungent, and used very largely with pickles when green.

Pkt., 5c; 0z., 20c; 2 oz., 35c; $1 / 4$ 1b., 60c; 1b., $\$ 2.00$

\section{PUMPKIN}

Pumpkins, though sometimes used for cooking, not compare favorably, as a table vegetable, ith the finer varieties of squash, but are better lapted and more profitable for stock feedins. hey do not require as rich soil as melons, and ie hills should be farther apart; otherwise the ent should be the same.

IARGE SWEET CHEESE-Large, flat, dishing the ends; flesh very thick, sweet, and nutriLarge Yellow, Fine for the table. kt., 5c; oz., 10c; 2 oz. 15c; 1/4 1b., 20c; 1b., 50c
MAMMOTH-The largest known, often weighing over one hundred pounds. Oval round, deep orange, slightly mottled; flesh not thick, but, on iccount of its enormous size, yields a very large amount of feed per acre. Also used for the table. Pkt., 5c; oz., 15c; 2 oz., 20c; $1 / 4$ 1b., 30c; 1b., $\$ 1.00$ IARGE YEIIOW or CONNECTICUT FIEIDA large, round variety, sometimes depressed at the ends; rind of a deep, glossy yellow. Vines vigorous and very productive. If protected, will keep well till midwinter.

Pkt., 5c; 0z. 10c; 2 oz., 15c; $1 / 4$ 1b., 20c; 1b., 45c

\section{RADISH}

The radish is cultivated for its root, which lould be eaten when young and tender, as in aturing it becomes strong, tough, and pithy. should be sown for early use as soon as the intervals of two or three weeks throughout season, in rich, loose, warm soil, as the qualdepends largely on its rapid growth. Sow if iws a foot aprart, and thin to two inches in the ent size for the table. Keep free from weeds ad well watered. In the heat of summer select cool, shady place.

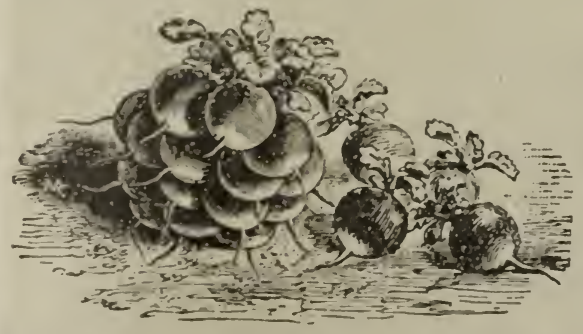

GARIY IONG SCARIET-The leading variety ther for the family or market garden. From six to eight inches long, standing noarly half above ground; bright scarlet, smooth, erisp, tender, and mild.

Pkt., 5c; 0z., 10c; 2 oz., 15c; 1/4 1b., 20c; 1b., 60c WOD'S EARIY FRAME-Shorter and thicker the preceding; a good variety for forcing, one of the best for first crop in the operi gar-

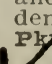

5c; oz., 10c; 2 oz., 15c; Ít 1b., 20c; 1b., 60c IONG, BRIGHTEST SCARIET WHITE TIPPED-Something new in the way of a long radish, and proving itself very useful and worthy of general cultivation; color strikingly briglit scarlet; tip white; general appearance very attractive. It is extra early and the flesh is very tender. Valuable for forcing or open ground.

SCARIET CHARTIER, Roots long, tapering rather abruptly, and attaining a very large size. Of rapid growth, it is soon ready for the table, remaining crisp and tender till fully grown. Color scarlet above, shading into white at the tip. Flesh white and mild flavored.

Pkt. 5c; 0z., 10c; 2 oz., 15c; 1'i 1b., 20c; 1b., 60c EARIY OTIVE-SHAPED or HATF TONG SCARIET-An excellent variety, of rapid growth, skin thin, flesh rose tinted and very tender; two or three inches long, with slender taproot.

Pkt. 5c; oz., 10c; 2 oz., 15c; 1, 4 1b., 20c; 1b., 60c 


\section{RADISH-Continued}

ARENCH BREAKFAST or HAIF IONG SCARIET, WIITE TIPPED-Medium size, of quick growth, crisp, and tender; terminates more
abruptly than the Half Long Scarlet; lower end abruptly than the Half AAIF IOIJG DEEP SCARIRT-A handsome riety, somewhat resembling the Olive shaped, but of a deeper scarlet, and havin : smaller tol.. Flesh tender and of the best quality; good for Plon, 5c; oz., 10c; 2 oz., 15c; 1/4 1b., 20c; 1b., 65c FARIY SCARIET TURNIP ROOTED-The ading turnip-shaped kind. Deep scarlet, small taproot; very crisp and tender. Of rapid growth, and, if sown with others, the first ready for the tablg. One of the best for forcing.

kc;. 5z., 10c; 2 oz., 15c; $1 / 4$ 1b., 20c; 3h., b0c TARIY SCARIET TURNIP, WHITE TIPPED - Similar in shape and size to the Scarlet Turnip Rooted, only that the under side of the bulb and taproot are white.

f., 5c; Oz., 10c; 2 oz.s 15c; 1/1. 1b., 20c; 1b., $65 \mathrm{c}$ NON-PIUS UITRA Or EARIY ROUND DEFP SCARIET FORCING-A handsome early kind. Deep scarlet, smooth, and crisp; very sho

Ply., 5c; oz., 10c; 2 oz., 15c; 1/4 1b., 20c; 1b., 65c EARIY WHITE TURNIP ROOTED-The best white turnip-shaped variety; pure white, small top, mild and crisp. Ready for the table in six weeks after planting.

Plyt., 5c; oz., 10c; 2 oz., 15c; 1/4 1b., 20c; 1b., 65c LONG WHITE VIENNA or TADY EINGFRThe best long. white radish grown; pure wnite, beauty of form and rapid growti.

Pkt., 5c; Oz., 10c; 2 oz., 15c; 1/4. 1b., 20c; 1b., 650
Che (5umer sorts; it covers a it is good when quite small. The roots are long,

Pkty., 5c; oz., 10c; 2 oz., 15c; 1/4 1b., 25c; 1b., 70c ROUND BIACK SPANISH-Roots round or shaped; skin black; flesh very white, fin€ for winter, as the roots keep a long time.

Pf.t. 5c; 0z., 10c; 2 oz., 15c; 1/4 1b., 20c; 1b., 60c

IONG BIACK SPANISH, FAII ON WINTERery hardy, and good for winter use. If stored in sand, will keep good all winter. The roots which present a rusty black appearance, are large firm, and not liable to become pithy.

Pkt. 5c; oz., 10c; 2 oz., 15c; 1/4 1b., 20c; 1b., 60c GOLDEN GIOBE or GOIDEN SUMIMIER-It hief peculiarity is its russet skin; form round flesh solid, white, and pungent.

Pkt., 5c; 0z., 10c; 2 oz., 15c; 1/4 1b., 20c; 1b., 65c CARIET CHINA, WINTER-A half-long va largest near the taproot; skin bright scar. let; flesh firm and more pungent than most others It is easily kept all winter.

plt. $5 \mathrm{c}$; oz., 10c; 2 oz., 15c; 1/4 1b., 25c; 1b., $80 \mathrm{c}$ AIAMMOTH CAIIFORNIA Or WHITE CHINA WINTER-Extensively grown by the Chinese who introduced it into California. It has now and cylindrical, terminating abruptly, with little taproot; mild and tender, and keeps well all win ter. The skin and flesh are of a transparen 1 white.

Pkt., 5c; oz., 10c; 2 oz., 15c; 1/4 1b.; 25c;1b., 80c

\section{RAPE}

DWARF ESSEx, for Sowing-This plant is used for pasture or for turning under as a green manure; valuable for sheep. Sow in drills at the rate of five pounds to the acre, or broadcast, ten pounds.

Pkt. 5c; 0z., 10c; 1b., 30c.

\section{RHUBARB OR PIE PLANT}

Rhubarb is extensively raised near all large cities, and should be more generally grown, as it is ready for use before most kinds of fruit are in the market. Its culture is very simple, and it yields every spring an abundance of leaf stalks, which are delicious when made into pies, tarts, and sauce. Sow in drills eighteen inches apart, and thin the plants to six inches. In the fall, trench or subsoil a piece of ground, manure very heavily, and transplant the young roots into it, three feet apart each way. Give a heavy dressing of manure annually and cut off the seed stalks as they appear, to prevent the plants from exhausting themselves by runing to seed. The seed Pkt., 5c; oz., 15c; 2 oz., 25c; 1/4 1b., 40c; 1b., \$1.25

\section{SALSIFY OR VEGETABLE OYSTER}

Salsify is a nutritious and wholesome vegetable having the appearance of a small parsnip, in flavor closely resembling oysters, for which it is, in that respect, a good substitute. It is rapidly coming into more general use. Sow early in the spring in drills a foot apart, and, when two or three inches high, thin out to three or four
inches. Its general culture is the same as that recommended for carrots. The roots are perfectly hardy, and may remain in the ground during winter, or may be stored in dry earth or sand.

MAMMOTH SANDWICH ISIAND-The leading variety; produces a large crop of straight, smooth roots.

Pkt., 5c; oz., 15c; 2 oz., 20c; 1/4 1b., 35c; 1b., \$1.25

IARGE WHITE-An early kind; tender and Pkt., 5c; oz., 15c; 2 oz., 20c; 1/4 1b., 35c; 1b., \$1.25

\section{SPINAGE}

A wholesome, palatable, hardy vegetable, mucr used for greens. It is easily grown, and may be had during the entire season. It will grow or almost any soil but is more tender and succulen when grown in soil heavily manured and well pul. verized. For a summer crop, sow early, in drills a foot apart, and thin gradually to six inches apart. For early spring use, sow in the fall, anc protect in cold climates with a covering of straw It should be cut back, using only the young lea tes; the old ones are tough and stringy.

NEW ZEAIAND, (new)-A favorite sort with stern market gardeners.

Pkt., 5c; oz., 15c; $1 / 4$ 1b., 25c; 1b., $75 c$

SAVOY IEAVED-A very early variety, 01 upright growth and pointed leaves, which art crinkled, like Savoy Cabbage. Grows quickly anc seeds early. Plant in autumn for early spring

Plzt/, 5c; oz., 10c; 2 oz., 10c; 1/4 1b., 15c; 1b., $40 \mathrm{c}$ ROUND SUMMER-An excellent variety for arly spring sowing. The leaves are round, thick and fleshy. Good for early market gardening.

Plyt., 5c; oz., 10c; \& oz., 10c; 1/4 Ib., 15c; 1b., 40c IMPROVID THICK IFAVED-The leaves this variety are unusually thick, fleshy and ten der. It is also hardy, and may be sown as soor as the ground can be thoroughly prepared.

Plyt., 5c; oz., 10c; 2 oz., 10c; $1 / 4$ 1b., 15c; 1b., 40r VICTORIA-This variety produces the larges eaves of any, yielding an enormous crop. Ex cellent for the family or market garden.

Plyt., 5c; oz., 10c; 2 oz., 10c; 1/4 1b., 15c; 1b., 40c IONG STANDING-An improved variety, hav ing thick leaves, that remain tender longer that any other, and on this account one of the bes: or market gardeners.

Pkt/ 5c; 0z., 10c; 2 oz., 10c; 1/4 1b., 15c; 1b., 40r IARGE PRICKIY SEEDED-The hardies ind, and may be sown in the fall, only requir. ing protection during the most severe frosts. Th seed is prickly, the leaves rather long and point ed, but thick and succulent.

Pkt., 5c; oz., 10c; 2 oz., 10c; 1/4 Ib., 15c; 1b., 40r 


\section{SQUASH}

\section{Summer Varieties}

Squashes are extensively grown, and embrace any distinct varleties. Their easy cultivation, normous yield, and nutritious qualities render e larger kinds one of the best and most profitble crops for stock feeding. The summer varities are ready for the table early in the season, hile the winter sorts can be kept until the early nds are again in the market. All kinds thrive st in loose, rich soil, under the same treatment that recommended for melons. The seed hould not be planted until danger of frost is st and the ground is warm. Plant the summer arieties four feet apart each $w a y$, and the winkinds, eight feet.

EARLY WHITE BUSH SCALLOP-The leading arly Bush Scallop variety; round, flat, with scaloped edges. The skin is white; the flesh is of cellent quality, and ready for use as soon as is large enough.

?kt., 5c; oz., 10c; 2 oz., 15c; 1/4 lb., 25c; 1b., 75c

MAMMOTH WHITE BUSH, SCAILOP-An im. rovement on the preceding in point of size, beng twelve to fifteen inches across; very producive, and uniform in growth.

?kt., 5c; 0z., 10c; 2 oz., 15c; 1/4 1b., 25c; 1b., 75c SUMMER CROOKNICK-An early, prolific ind, lhaving a solid. curved neck; the skin is rellow, thin, hard, and very warty; flesh tender nd of good quality.

?lst., 5c; 0z., 10c; 2 oz., 15c; 1/4 1b., 25c; 1b., 75c MAMMOTH SUMMER CROOKNECK-TWice he size of the ordinary Summer Crookneck, also arlier and more warty; a decided advance on the ld kind.

3kt., 5c; oz., 10c; 2 oz., 15c; 1/4 1b., 25c; 1b., 75c

WHITE SUMMER CROOKNECK-A comparavely new but decidedly excellent summer vari:ty. Similar to the Crooknecks, but ivory white $n$ color; of good quality and flavor, and sure to secome a favorite.

?kt., 5c; oz., 10c; 2 oz., 15c; $1 / 4$ 1b., 25c; 1b., 75c

\section{Late or Winter Varieties}

BOSTON or VEGETABLE MARROW-A lead$n g$ variety, ripening early in the fall, but keepng well through the winter; oval round, mottled dark and light yellow; flesh salmon colored, remarkable for its rich, sweet flavor.

Pkt., 5c; oz., 15c; 2 oz., 20c; $1 / 4$ Ib., 30c; 1b., 85c

MAMMOTH CHIII-The largest variety grown, having attained a weight of over two hundred pounds. Round, flattened at the ends; rind deep orange; flesh dark yellow, thick, and very nutritious. Sometimes used for the table, but more desirable for stock feeding. It is a good keeper.

Plrt., 5c; oz., 15c; 2 oz., 20c; $1 / 4$ lb., 30c; 1b., $\$ 1.00$

FIELD MARROW-A mixture of marrow.varieties to be planted for feeding dairy cows and other stock. Yields a large crop.

Pkt., 5c; oz., 10c; 2 oz., 10c; $1 / 4$ 1b., 15c; Ib., 30c; 25 to 100 lbs., write for price.

HUBBARD-One of the best and most popular kinds; rind bluish green, and very hard; flesh remarkably dry, either baked or boiled, and not surpassed in richness and sweetness by any. It is also easily kept all winter.

Plst., 5c; oz., 15c; 2 oz., 25c; 1/4 Ib., 35c; 1b., $\$ 1.15$

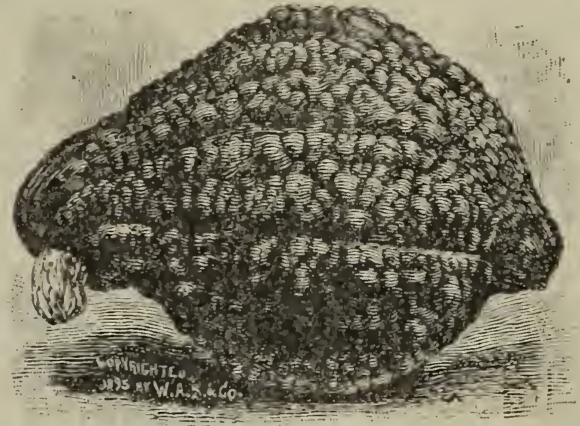

GOLDEN HUBBARD-Flesh deep orange, skin orange to red in color; of excellent grain and flavor. Vine vigorous and very productive, maturing its crop early; fruits six to eight pounds each, which are good keepers. Considered the best winter variety, and likely to become a favorite.

Plkt., 5c; 0z., 15c; 2 oz., 20c; 1/4 1b., 30c; 1b., $\$ 1.00$

\section{SUGAR CANE OR SORGHUM}

The climate of the Pacific Coast south of the olumbia River, and the soil of most of the alleys and river bottoms, are so similar to those of the Southern States, Hawaiian, and West India slands, where the sorghum canes form so large Ind profitable a staple, it is surprising that more ittention is not paid to their cultivation, and esjecially when it is known that they afford one of the most prolific and profitable crops for cattle eeding known to the husbandman. We offer the :wo best varleties, and believe it will be to the idvantage of farmers to give them a trial, for he production of both sugar and syrup, and for stock feeding. Cultivation the same as for corn.
EARIY AMBER-Early and of rapid growth, best for sugar and syrup, making a rich, ambercolored syrup, and granulating into sugar beautifully.

\section{Pkt., 5c; 1/4 1b., 15c; 1b., 30c.}

EARIY ORANGE-Of more vigorous growth and but little later than the Amber. It is good for sugar and syrup, and, on account of its unusually large yield, is the most profitable kind for stock feeding.

Pkt., 5c; 1/4 1b., 15c; 1b., 30c.

\section{TOBACCO}

CONNECTCUT SEED IEAF-Hardy, and the is

Pkt., 5c; oz., 25c; 2 oz., 35c; 1/4 1b., 60c; 1b., \$2.00 Pkt., 5c; oz., 40c; 2 oz., 70c; 1/4 1b., \$1.25; 1b., \$4.00
IAVANA-Of fine texture and delicate flavor. Celebrated for its value in the manufacture of fine cigars. 


\section{TOMATO}

Marked improvement has recently been made in the tomato. Its value as a table vegetable can hardly be overestimated. Its healthfulness during the heat of summer, and especially for bilious temperaments, is well known, and a diet composed largely of tomatoes, both raw and cooked, is a powerful aid in warding off the effects of malaria. The first step toward success, after obtaining good seed, is to produce strong, healthy plants. For early crop, sow as soon as desired in hotbeds. When two inches high, transplant in the beds to four or five inches apart each way, to give the plants room and make them bushy, always keeping them well aired. If they crowd each other before time to transplant, root prune by drawing a sharp knife deeply between the plants. When danger of frost is past, transplant to rich, loose soil, keeping well watered and cultivated. For later crop, sow in cold frames or open ground, and transplant when four to six inches high. If possible, support the vines. Thus treated, they will continue in bearing much longer, and the fruit will be greatly improved.

SPARK'S FARIIANA-The earliest tall variety, forming ripe fruit much earlier than any other variety. The fruit is large, smooth, of a bright scarlet color, and of fine quality. Very valuable for early market use.
Pkt., 10c; 0z., 40c; 1/4 Ib., \$1.00; Ib., \$3.50.

ATIANTIC PRIZE, EXTRA EARIY-A distinctly early variety, of good size and smooth surface. Many of the objections to the usual early kinds, such as under size, deep corrugations, and rough skin, are overcome in the Atlantic Prize.

Pkt., 5c; oz., 25c; 2 oz., 45c; 1/4 1b., 80c; 1b., \$2.7s

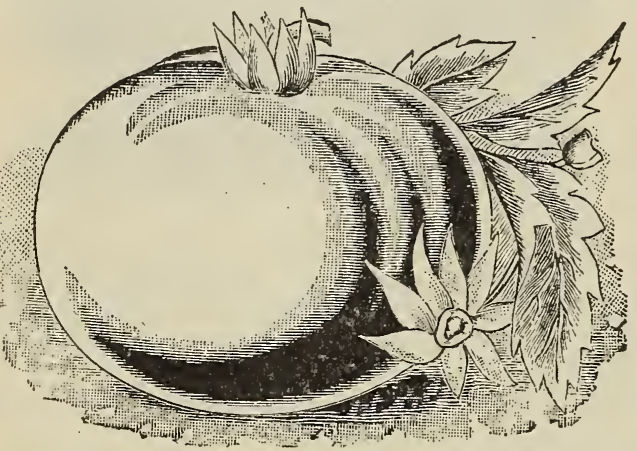

FARIY MICHIGAN-An extremely smooth perfectly-shaped tomato; solid, and without core Vines large and vigorous. A heavy cropper, and one of the earliest.

Pkt., 5c; oz.; 25c; 2 oz., 45c; 1/4 1b., 80c; 1b., \$2.75 ACME-Also early and popular. The fruit is smooth, handsome, solid, and of good quality. A good bearer. Color dark purplish red. A su- perior early market variety, and ripens evenly kt., 5c; oz., 20c; 2 oz., 35c; 1/4 1b., 60c; 1b., $\$ 2.0 \mathrm{c}$ PFRFECTION-One of the best medium early kinds; round, uniformly smooth; vines very pro. ductive; fruit deep scarlet, firm, and of excellent quality. Vines continue long in bearing.

Pkt., 5c; oz., 20c; 2 oz., 35c; 1/4 1b., 60c; 1b., $\$ 2.00$

IAVORITE-One of the best for general crop vines vigorous. continuing in bearing all the season; fruit very large, uniformly smooth, firm, without hard core; ripens medium early; holds its size well till frost. Is very fleshy, with few seeds.

Plkt., 5c; oz., 20c; 2 oz., 35c; 1/4 1b., 60c; 1b., $\$ 2.00$

TROPHY (Selected Stock)-We offer selected stock of this well-known, popular variety. It ripens just after the Perfection; vines vigorous, continuing in bearing till frost; fruit large, bright scarlet, firm, and of the best quality, eíther fresh for table use or for canning.

Plkt., 5c; oz., 20c; 2 oz., 35c; 1/4 1b., 60c; 1b., $\$ 2.0 \mathrm{C}$

STONF-A large tomato of good quality; round or apple shaped, and very uniform, deep red in color, and exceedingly heavy.

Pkt., 5c; oz., 20c; 2 oz., 35c; 1/4 1b., 60c; 1b., $\$ 2.0 \mathrm{C}$

DWARF ARISTOCRAT-Plant dwarf and compact; fruit medium size; rich, glossy red; smooth and solid. Fine for private gardens.

Pkt., 5c; oz., 35c; 2 oz., 60c; 1/4 1b., \$1.00; 1b., $\$ 3.50$

BEAUTY-A distinct variety, uniformly large; color deep crimson, inclining to purple. The vines, which are vigorous, continue to bear large handsome fruit till the close of the season. It has but few seeds, and its handsomely-grained flesh is of superior quality. It has few equals, either for the family or market garden.

Pkt., 5c; oz., 20c; 2 oz., 35c; 1/4 1b., 60c; 1b., $\$ 2.00$ DWARF CHAMPION OT TREF TOMATOVines erect and vigorous; fruit of medium size, round, smooth of excellent quality, very fleshy; approaching purple in color

Pkt., 5c; oz., 35c; 2 oz., 60c; 1/4 Ib., \$1.00; 1b., \$3.50 OPTIMUS-A second early kind; uniform in size; color bright red; smooth and handsome. Our stock is the very best.

Pkt., 5c; oz., 20c; 2 oz., 35c; 1/4 Ib., 60c; Ib., $\$ 2.00$

GOIDEN QUEFI-Very handsome when prepared for the table; flesh rich and of superior quality.

Plt., 5c; oz., 30c; 2 oz., 50c; 1/4 1b., 85c; lb., $\$ 3.00$ RED PFAR SEAPED, YEILOW PIUIM, RID CFrRRY-Small, handsome tomatoes, resembling the different fruits named; used for pickles, preserves, and ornamentation. Seed sold separate or mixed.

Pkt., 5c; oz., 30c; 2 oz., 50c; 1/4 1b., 85c; 1b., \$3.00

HUSK TOMATO OT GROUND CHERRY-A small, yellow sort, much used for preserving; alsc good eaten fresh from the vines.

Pkt., 5c; oz., 30c; 2 oz., 50c; 1/4 1b., 85c; 1b., \$3.00

\section{TURNIP}

The turnip is a nutritious, wholesome vegetable, of fine texture and delicate flavor and easily affected by soil and cultivation. White-fleshed varieties are apt to deteriorate in quality if overgrown or left in the ground too long after maturing. The best results are obtained in rich, mellow soil, adding, if possible, a dressing of wood ashes. Rotted manure should be avoided, having a tendency to make turnips rough, wormy, and strong. They are hardy, and may, in mild climates, be sown as soon after rain as the ground can be prepared, either broadcast or in drills twelve or eighteen inches apart and half an inch deep, thinning to six inches apart in the drill. The ruta baga, which is extensively grown for feeding stock during winter, is sown later, in rows two or three feet apart, and thinned to ten inches in the row. Both ruta bagas and turnips may be kept through the winter by storing in a cool, dry place, and covering with straw, or by burying in clean, dry sand. Our list includes the choicest varieties.

\section{White-Fleshed Kinds}

FXTRA FARIY WHITE MIIAN-This variety is ready for the table sooner after planting than any other yet introduced. Top small, erect, strap leaves; bulb a deep purple above, white underneath; flesh white, firm, and delicate. Remains tender and in condition for the table a long time. Pkt., 5c; oz., 10c; 2 oz., 15c; 1/4 1b., 25c; 1b., 80c

FXTRA EARIY PURPLE-TOP MIIAN-SAmE as above, but pure white.

Pkt., 5c; oz., 10c; 2 oz., 15c; 1/4 1b., 25c; 1b., 80c 


\section{TURNIP-Continued}

\section{White-Fleshed Kinds}

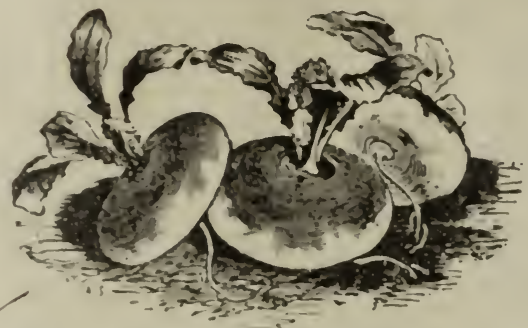

POMLRANEAN WHTE GLOBE-A pure white, snooth-skinned turnip, growing in good soil to a very large size; almost perfect globe shaped; good for stock or table.

Ply 5c; 0z., 10c; 2 oz., 10c; 1/4 1b., 15c; 1b., 45c

SWEET GERMAN-A round turnip, white, solid, and sweet, but peculiar in the fact that it partakes of the nature and suggests the flavor of the ruta baga. Should be sown three or four weeks earlier than the flat varieties. A good keeper and a favorite in the Eastern States.

Pkek, 5c; oz., 10c; 2 oz., 15c; 1/4 1b., 20c; 1b., 50c

COW HORN or IONG WHITE-A distinct valiety, having a long, slightly-curved root, somewhat resembling a carrot. It is white, with a green tint near the top, growing partly aboveground; flesh tender, sweet, and of fine quality. Can be sown early for fall and winter use.

Pkt., 5c; oz., 10c; 2 oz., 15c; $1 / 4$ 1b., 20c; 1b., 65c

\section{Yellow-Fleshed Varieties}

kt. $5 \mathrm{c}$; Oz., 10c; 2 oz., 15c; 1/4 1b., 20c; 1b., 50c SARIY PURPIE TOP STRAP IEAVED-ONE and most universally grown. Small, ound flat; purplish red above, white
flesh firm, but very tender and sweet. quick growth, it is soon ready for the table,
quick 'kt., 5c; oz., 10c; 2 oz., 15c; $1 / 4$ 1b., 20c; 1b., 50c PURPIE TOP WHITE GIOBE-A large lobe-shaped variety; purple above ground; it is andsome and of excenty garden and field crop. 'kt., 5c; oz., 10c; 2 oz., 15c; $1 / 4$ 1b., 20c; 1b. 50c WHITE EGG-An oval or egg-shaped variety, rowing much aboveground. It is pure white, and handsome; flesh tender and excellent. rapid growth, and recommended for early LARGE AMBER GIOBE-Large, rather globe sweet and of good quality. It is hardy, produces a large crop, and keeps well. Good both for the table and field crop.

Pkt., 5C; 0z., 10c; 2 oz., 15c; 1/4 1b., 20c; 1b., 50c

ORANGE JELIX OY ROBERTSON'S GOIDEN BAII-One of the best yellow-fleshed kinds; not large; rather globe shaped; flesh fine grained, firm. sweet, and of superior flavor. Keeps well all winter.

Pkt., 5c; oz., 10c; 2 oz., 15c; $1 / 4$ 1b., 20c; 1b., 50c PURFIE-TOP YELIOW ABERDEEN-ROund, size, light yellow, stained with purple on top. Produces a large crop, is hardy, and keeps well; flesh very firm, but tender and sweet. kt., 5c; oz., 10c; 2 oz., 15c; 1/4 1b., 20c; 1b., 50c. Plt., 5c; oz., 10c; 2 oz., 15c; 1/4 1b., 20c; 1b. 50c

\section{RUTA BAGAS OR SWEDES}

Ruta hagas are larger and coarser in flesh much aboveground, making them easier to harhan turnips, but yield more weight per acre, richer and more nutritious, and for these referred for stock feeding, for which ry profitable. They are also used on Pkt., 5C; 0z., 10c; 2 oz., 15c; 1/4 1b., 20c; 1b., 50c

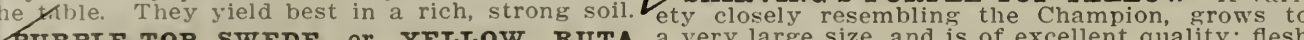
IAGA-A large variety, growing much above- very firm. Easily kept all winter.

hardy, and should be sown as early Pkt., 5c; oz., 10c; 2 oz., 15c; 1/4 1b., 20c; 1b., 50c ound can be prepared; ashy purple on

\section{b} llow underneath. A large cropper and a SWEET RUSSIAN Or WHITE RUTA BAGAtivation; is hardy, easily grown, large, and yields MONARCE or TANKARD-This is a tankardhped sort; color purplish crimson above ground, ellow below. The flesh is of a rich yellow, fine

\section{AROMATIC, MEDICINAL,}

ANISE (Pimpinella Anisum)-For garnishing nd seasoning. The seeds are also used medicnally. They have a powerful aroma, are tonic, yspepsia. Annual.

Pkt., 5c; oz., 15c; 2 oz., 20c; $1 / 4$ 1b., 30c

BAIM (Melissa officinalis)-A fragrant, lemoncented herb, used for making balm tea or balm vine. It is easily grown from the seed, or multilied by dividing the roots. The tea is a febrifuge, ossessing considerable virtue, and the wine exellent to allay thirst. Hardy peremnial.

Pkt., 5c; oz., 25c; 2 oz., 40c; $1 / 4$ 1b., 75c

BASII, SWEET (Ocymum Basilicum)-The eaves and top shoots are used for seasoning ups, stews, and sauces. Hardy annual.

Pkt., 5c; oz., 15c; 2 oz., 25c; $1 / 4$ 1b., $40 c$ as heavy a crop as the best yellow kinds; flesh vored; good for stock and desirable for the table. Pkt., 5c; oz., 10c; 2 oz., 15c; $1 / 4$ 1b., 20c; 1b., 50c

\section{SWEET AND POT HERBS}

CATIIP (Nepeta Cataira)-A mild nervine. As a tea it is excellent for children. For winter use, remove the plant by the root, and dry as other herbs. Hardy perennial.

Pkt., 5c; oz., 35c; 2 oz., 60c; $1 / 4$ lb., $\$ 1.00$

DIII (Anethum Graveolens) - A hardy annual, the seeds of which are aromatic, warm, and pungent, and are used medicinally in cases of colic and to correct flatulence. They are also used to flavor soups and stews, and in pickles. The leaves possess similar qualities and can be used in the same manner as the seeds.

Pkt., 5c; oz., 15c; 2 oz., 20c; $1 / 4$ lb., 35c.

FENNEI, SWEET (Foeniculum vulgare)-The leaves are used for ornament, also much esteemed for flavoring fish sauces. The seeds have an greeable aroma, and are used in confectionery, for flavoring, and medicinally. Hardy annual. Pkt., 5c: oz., 15c; 2 oz., 20c; $1 / 4$ 1b., 30c 
Frssor (Hyssopus officianalis) - The leaves universally, as a condiment for relishes and fla and flowers are the parts used, and have a warm, aromatic, pungent taste. Medicinally it is a tonic and expectorant, acting on the bronchial tubes, and is beneficial in cases of asthma and catarrh. A hardy perennial, maturing best in a dry, sandy soil. The hyssop of Scripture is supposed to be a species of the caper.

Pkt., 5c; 0z., 20c; 2 oz., 30c; 1/4. 1b., 50c

IAVENDER (Lavendula vera)-So called from its extensive use by the Romans in the bath. It is cultivated for the powerful and delicious fragrance of its flowers, which should be gathered when in full bloom, dried quickly, and carefully
protected from the air and moisture. Hardy perennial.

Pkt., 5c; oz., 20c; 2 oz., 30c; 1/4 1b., 50c

IMAJORAIM, SWEET (Origanum Marjorana)A perennial in warm climates, but unable to with-
stand severe winters. The young shoots and leaves are peculiarly aromatic, and are used for flavoring, either fresh from the garden or dried.

Pkt., 5c; oz., 20c; 2 oz., 30c; 1/4 1b., 50c

RUE (Ruta graveolens)-A stimulant in medicine, but, on account of its powerful acrid effect, should be used with great care. The plant should not be allowed to run to seed, or the young shoots
should be cut before the seed matures, or they lose their strength. Hardy perennial.

Pkt., 5c; 0z., 35c; 2 oz., 60c; 1/4. 1b., $\$ 1.00$

SAGE (Salvia officinalis)-Sage is used, almosı

voring. Used medicinally, it is diuretic in effect producing gentle perspiration. It is a hardy pe rennial, that should have rich soil and thorough cultivation. Cut the young shoots just before blooming, dry quickly in the shade, and stort carefully, or pulverize and bottle.

Pkt., 5c; oz., 20c; 2 oz., 35c; 1/4. 1b., 60c

SAVORY, SUMMIER " (Satureia Hortensia)-Cul. tivated for the young shoots, which are dried anc used for flavoring soups, dressings, and meats It is a hardy annual, and may be sown as soon as the ground can be prepared.

Plkt., 5c; oz., 15c; 2 oz., 20c; 1/4. 1b., 35c

SORREI (Rumex asetosa)-A hardy perennia: plant, much prized by the French. It has a sour taste, and is used as a salad, and by some ir soups and sauces. Can be propagated by dividing the roots. To secure a good growth of Pkt., 5c; oz., 25c; 2 oz., 35c; 1/4. 1b., $60 \mathrm{c}$

THYME (Thymus vulgaris)-A hardy perennial, a warm, pungent, and very aromatic plant much used for flavoring soups, dressings, etc It is also a nervine, and tea made from the ous headache. It can be used either fresh or dried. Plant as soon as the ground can be prepared. Pkt., 5c; 0z., 25c; 2 oz., 40c; 1/4. 1b., 65c

\section{CLOVER AND GRASS SEEDS}

Clover and grass seeds at pound prices include postage or express charges prepaid at our exfreight at buyer's expense for charges.

As the country becomes settled, and lands that have been used for grazing only are inclosed and devoted to agriculture or the growing of fruits, the question of economically raising and fattening stock for market becomes a most important one. To solve the problem, the farmers are fast turning their attention to the raising of grass and clover. Fully appreciating the growing importance of this branch of husbandry, we are constantly adding to our facilities to meet every requirement of our largely-increasing trade.

AIFAIFA (Medicago sativa)-Alfalfa, also known as Lucerne and Chili clover, is one of the most valuable forage plants, yielding a prodigious amount of feed, which is relished by all kinds of stock, and is very nutritious. It should be cut cially valuable for dairy cows. As soon is espeit immediately commences to grow, and during the hottest and driest weather, when other grasses are parched and withered, it remains fresh and green, and grows as rapidly as ever. Prepare the land by deep plowing and thorough harrowing. Sow from twenty to thirty pounds of seed to the acre, and harrow or brush it in well. Seeding thick will produce fine stalks-a desirable feature, either in hay or pasture. The seed should be sown in spring, after danger from freezing the young plants is over, or in the fall, early enough give it a good stand before frost.

Per 1b., 30c; 100 lbs. and over, write for price.

RED CIOVER (Trifolium pratense) - The standard clover for all purposes, either pasture, is hardy, and may be sown at any time wher the ground is in condition to receive the seed. It succeeds well on any good soil, and thin, light lands are made fertile and rich by allowing them yields the heaviest crop of any clover except alfalfa, and makes superior hay, especially if mixed with timothy, either for dairy cows or general use. Sow from twelve to fifteen pounds per acre, being careful to get it evenly distributed over the ground.

Per Ib., 30c: 10 to 25 Ibs., at buyer's expense for freight, 16c per lb.; 100 lbs. and over,

write for price.

MAIMMOTE RED CLOVER (Trifolium pratense)-Similar to Red Clover, but coarser and taller, and considered of more value for reclaim-

ing and enriching waste lands, as it sustains itself, and succeeds sometimes when Red Clover fails. Sow from twelve to fifteen pounds per acre in time to get the benefit of ample moisture. Per 1b., 35c; 10 to 25 lbs., at buyer's expense for freight, 20c 1b.; 100 lbs. and over, write for price.

WHITE DUTCF CLOVER (Trifolium repens)A small variety, having a white blossom. It is of a vining nature, spreading rapidly, and will soon cover bare spots if the stand be uneven. It does not attain sufficient height to be profitable for hay, but is superior for pasture either for cattle or sheep, and unsurpassed for the production of honey. It also makes a beautiful lawn, mixed with blue grass. When sown alone, use eight to ten pounds per acre. Harrow the soil until it is very fine before sowing:

Per 1b., 45c; 10 to $25 \mathrm{lbs}$., at buyer's expense for freight, 30c 1b.; 100 lbs. and over, write for price.

AISIKE or SWEDISH CIOVER (Trifolium hybridum)-A comparatively new and perfectly hardy variety, which is rapidly growing in popular favor. It yields large crops of excellent hay. and, under favorable conditions, may be cut several times during the season. It is also valuable for bees. It is well calculated to resist both drought and excessive moisture. It is perennial, and produces a mass of long, fibrous roots, which hold the soil, making it useful for permanent pasture on hillsides which are liable to wash. When used alone, sow from six to eight pounds per acre.

Fer 1b., 30c; 10 to 25 lbs., at buyer's expense for freight, 18c lb.; $100 \mathrm{lbs}$. and over, write for price.

THMOTFY (Phleum pratense)-Timothy is indigenous in North America, and takes its name from Timothy Hanson, who first introduced it into England. It is nutritious, and relished by all herbivorous animals, either as pasture or hay. In moist soils it affords excellent pasture in the fall after the hay has been harvested. It should be cut just before or immediately on coming into bloom, as it loses much of its strength and flavor, and becomes hard and strawy, if allowed to ripen. It is perennial, sods readily on any good soil, and does not fail even on clayey lands when well prepared. It yields a moderately heavy crop of hay, that should be well cured, to prevent molding, and salted as it is mowed or stacked. To secure a 


\section{CLOVER AND GRASS SEEDS-Continued}

he acre.

$25 \mathrm{c}$ : 10 to 25 lbs., at buyer's expense for frelght, $18 \mathrm{c}$ lb.; 100 lbs. and over,

write for price.

ORCFARD GRASS (Uactylus Eloinerata) - Also as cock's Foot. A tall grass, liaving large, It is justly becoming more popucount of its rapid growtl. being ready for ng ten to fifteen days carlier than most kinds, and, where the ground is kept moist, inues io grow vigorously as fast as eaten
till late lil fall, and in warm localities all It yelels a heavy crop of has, and sucwell in olen tinber lands. If intended for only, it is usually mixed with clover, as they loom at the same tine, and can be cut
th their best. It is perennlal, and lias a y to grow in tufts. and should be sown to furty pounds lier acre to secure the best

'er 1b., 30c: 10 to 25 1bs., at buyer's expense for frelght, 18c 1b.; 100 1bs. and over, write for price.

RED TOP (Agrostis vulgaris)-Also known in ome sections as Herd's Grass, and by some as perennial. and the best yield is obtained on and even marshy land. The blades and stalks fine, and generaily preferred for grazing; but le hay crop. The seed is fine and light, and
le the and stand is secured, it affords a profit-
. The and re should be taken to get it sown evenly. The
roper quantity is thirty pounds per acre for quantity is thirty pounds per for fancy.

zed Top, in chaff, 1b., 25c; Red Top, fancy, clean, free from chaff, 1b., 35c.

RARD FEscug (Festuca Duriuscula) - A fine, ther dwarf-growing variety, justly noted fo drought-resisting qualities. It is prized by asture for shecp, as it succeeds well sown on ncultivated land where the soil is loose. Sow hirty pounds per acre.

\section{Ib., $40 \mathrm{c}$}

KENTUCKY BTUE GRASS (Poa pratensis)ne of the best grasses for permanent pasture, ious feed during the greater part of the year $t$ is perennial, and in warm localities, where the round is kept inoist, and it is pastured or freluently cut to rrevent the seed from ripening, $t$ is also incomparably the best grass known for awns and parks, and. where covered with fine nanure every fall. watered well and evenly, and ut frequently. Will furnish a handsome, velvety awn for rears, recuiring no resowing. For pas-
ure. sow forty to fifty pounds to the acre, but to secure a fine lawn, much leavier secding is retuired, and not less than righty pounds should Fancy clean, $35 \mathrm{c}$ ver 1b.; 10 to $251 \mathrm{bs}$., at buyer's
expense for freight, $25 \mathrm{c} 1 \mathrm{~b} .: 100 \mathrm{lbs}$. and over, write for price.

ENCIISH PERENWIAI RYE GRASS (Lolium erenne)-A strong-growing, hardy, perennial grass, noted for its nutritive qualities. It is will succeed on any good, tillable land, if well prepared. It is easily cured. and kept either in he mow or stack. Also makes a fine lawn, and or large grounds and rarks is very successful. Does not require the close care that Blue Grass oes, and will flourish better under trees or in Shady locations. For field crop, sow forty to ifty pounds to the acre, and if

cb., $25 \mathrm{c} ; 10$ to $25 \mathrm{lbs}$., at buyer's expense for freight, $121 / 2 \mathrm{c}$ lb.

Extra heavy for lawns and parks, $1 \mathrm{~b}, 30 \mathrm{c} ; 10$ to 25 lbs., at buyer's expense for freight, 15c lb.; 100 1bs. and over, write for price. ITATIAN RYE GRASS (I, parts of Europe. One of its chief points of meric are short, either from limited rains or long. severe winters, this rariety is found valuable Though a distinct varlety, its qualities are similar to the English Perennial, and will succeed acre sliould be sown.

Per 1b. 30c; 10 to 25 1bs., at buyer's expense for freight, $15 \mathrm{c} 1 \mathrm{~b}$.

TAII OAT GRASS (Avena elatior)-Valuable In mixturis tor permanent pastures in dry, gravelsoil. 1t is perennlatio molsture. Sow thirty or forty pounds per acre when used alone.

Per 1b., 35c

FINE-IEAVED FESCUE (Festuca tenuifolia) One of the best of all grasses for sheep, and should be used in all mixtures for perinanent pasture. It is still finer than the Hard Fescue,
and, like it, succeeds on virgin soil. Sow thirty and, like it, succecds on virgin soil. Sow thi
pounds per acre, if possible, just before rain. Per 1b., $45 \mathrm{c}$

BROME GRASS (Bromus inermis)-A variety coming from IIungary and the northern provinces of Turkey. It is nutritious, and yields a not inferior to alfalfa. It comes highly reconmended as a variety that will mature a goou crop with an astonishingly small amount of moisture, succeding where most other kinds fail.
We deem it worthy a thorough trial by farmers and stock raisers, on virgin soil and in dry sections. Thirty pounds per acre should be sown.
Per lb., 35c; 10 to 25 lbs., at buyer's expense for freight, 15c 1b.; 100 lbs. and over. write for price.

BERMUDA GRASS (Cynodon dactylon)-Suitable only for climates where the winters are not below the freezing point. Particularly adapted and dryest season, and is very valuable for stoch, being exceedingly nutritious, and for summer pasture is rery valuable. Sow eight to ten is all that is necessary to make a sufficient covering. It is slow to germinate, requiring at least Per Ib., 75c; $\mathbf{5}$ 1bs., by mail or express, prepaia, $\$ 3.50$

MIXTURE FOR DRY IANDS-Our mixture for permanent pasture is composed of a variety of grasses, selected especially for their ability to survive drought, ponr soil, close feeding, and for
their nutritive and lasting qualities. We recommend it as the best mixture to be liad for the use for which it is designed. Fifty pounds to the

Per 1b., 35c; 100 1bs. and over, write for price.

IAWN GRASS-Nothing adds a greater air of refinement to a home than a handsome. well-kept lawn. It not only increases its value financially, but renders it doubly valuable in the higher sense of enjoyment. and is within the reach of all who have the ground to devote to it. The cost need not deter anv. if leisure hours are devoted to its care. The directions we gire to secure a good lawn, when using Fxtra and Fancy Clean Kentucky Blue Grass, will be equally successful when mixtures are sown. Cut with a lawn-mower frequently, and water thoroughly and erenly immediately after mowing. This will make it fine and velvety. This mixtures includes fine perennial varieties in proper pronortions to secure a close and permanent sod. Fifty to sixty pounds of seed should be sown to the acre, or one and a half pounds to a plat of ground twenty feet square.

Fine Mixed, 1b., 30c; 10 to 25 lbs., at buyer's expense for freight. $18 \mathrm{c} 1 \mathrm{~b}$.

Extra Fine Mixed. 1b., $40 c$ : 10 to 25 lbs., at buyer's expense for freight, 25c lb.; 100 1bs. and over, write for price.

MEADOW FESCUE or ENGIIST BIUE GRASS

\section{(Festuca Pratensis) - A parennial variety grow-} ing from three to four feet high. It roots deep. and on this account resists drought better than and on the continent. It succceds in ans orlinary soil, and well repays the labor of deep plowing and thorough harrowing in preparing the land. It ylelds a heavy crop of superior hay, and is one 


\section{CLOVER AND GRASS SEEDS-Continued}

of the best kinds for pasture, as it comes early and remains green until late. It is valuable to mix with other kinds, as it sometimes succeeds where others fail. Use thirty pounds per acre when sown alone.

Ib., 30c; 10 to 25 lbs., at buyer's expenses for freight, $18 \mathrm{c} 1 \mathrm{~b}$.

MIILET, COMIMON (Panicum miliaceum)-A variety growing from three to four feet high, having rather broad blades and strong stalks. It supplies a valuable hay crop, and affords excellent pasturage. The seed is also extensively sold in the market and used with mixed bird-seed. It should have rich, mellow soil, well prepared. For a seed crop, sow fifteen pounds per acre; for hay and pasture, use thirty pounds. Annual.

Per 1b., 25c; 10 to $25 \mathrm{lbs.,} 7 \mathrm{c}$ per 1b.; by freight or express, charges collect; $100 \mathrm{lbs}$. write for price.

MILIFT, GFRIMAN or GOTDEN (Panicum Germanicum var)-An improved variety, yielding a larger crop of seed than the Common Millet. It is also taller than the common, and yields a heavier crop of hay. The grains of seeds are larger and of a deeper orange yellow. For a crop of seed. sow twelve to fifteen pounds per acre; for hay, twenty-five to thirty pounds. Annual.

Per 1b., 25c; 10 to $25 \mathrm{lbs.,} \mathrm{8c} \mathrm{per} \mathrm{1b.;} \mathrm{by} \mathrm{freight}$ or express, charges collect; 100 lbs., write for price.

\section{Seed Potatoes}

We carry a good line of very early and medium early kinds, such as Early Ohio, Early Wonder, Select Farly Rose, Early Michigan, Daybrean, Farly Bover, Uncle Sam, as well as the ever popular Burbanks. Write for prices.

\section{Seed Wheat, Seed Rye, Seed Oats}

We carry all the leading as well as new varieties for spring and fall sowing. Write for further information and prices.

\section{Buckwheat}

SIIVFR HUILI-A very good and popular variety. Grain is of a light gray color, rounder than the common; has a thin husk; matures earlier and yields heavy. A good milling variety. Per 1b., postpaid, 15c; 100 lbs., $\$ 3.50$

JAPANESE-This variety excels all others; yield much heavier; ripens one week to ten days earlier; stands up better and makes better flour. Excellent for bee pasture.

Per 1b., postpaid, 15c; 100 1bs., $\$ 4.00$

\section{Cow Pea}

These so-called 'Cow Peas" are really a small bean of strong running growth, with a large and abundant glossy, dark-green foliage. Most desirable for enriching the soil and for furnishing a large crop of nutritious forage. These so-called "Cow Peas" gather quantities of nitrogen from the air, a portion of which is conveyed to the soil by the roots, but a much larger amount can be storea in the soil for fertilizing by allowing the vines to die down and plowing them under. They yield as high as five to.nine tons of green feed per acre. The vines may be cut either for feeding green or can be cured like clover for winter use. Sow two bushels per acre.

WHIP-POOR WIII-The earliest maturing variety of upright or bush growth. The seeds may be gathered and the plants harvested more readily than with the running type of growth.

Per 1b., postpaid, 20c; by freight or express, 10 1bs., 90c; 100 lbs., $\$ 7.50$

\section{Field Peas}

Field Peas are a very profitable crop and are grown here very extensively. They can be grown alone or with oats. When planted with grail? and cut green they make a large amount of very rich feed; also very valuable for enriching the soil if plowed under. The dry peas make excellent hog feed and are quite fattening. Sow, if alone, 120 pounds to the acre; if with other grain, 60 pounds.

WIITE CANADIAN-A leading kind; seed almost white; a heavy cropper.

Per 1b., postpaid, 15c; 100 lbs., $\$ 3.50$

BIUE PRUSSIAN-Very much like the above, except in color. This variety is largely sold for soup peas.

Per 1b., postpaid, 15c; 100 1bs., \$3,75

\section{Bird Seed}

Not for Planting.

S. S. Co.'s Best Mixed....... Per 1b., postpaid, 20c Canary-Best Recleaned .....Per 1b., postpaid, 20c Hemp ................Per lb., postpaid, 20c Millet $\ldots \ldots \ldots \ldots \ldots \ldots \ldots \ldots \ldots$ Per lb., postpaid, $20 \mathrm{c}$ Rape $\ldots \ldots \ldots \ldots \ldots \ldots \ldots \ldots$ Per lb., postpaid, $20 c$ Cuttle Bone. Large Bone........Postpaid, 2 for 5c

\section{Barley}

BEARDIRSS-The earliest barley known. The straw is about the height of the common barley, but better, and will stand up on any land; with good season and land has produced 80 bushels per acre. Sow as early as you can; frost does not hurt it. Many farmers will not grow barley on account of the long, harsh beards which are so disagreeable in threshing, although it is a profitable crop. This is beardless, and as easy to grow and handle as oats. It is becoming more popular each season.

$$
\text { Per 1b., postpaid, 15c; } 100 \text { 1bs., } \$ 2.75
$$

CHIVAIIER BARIEY-A great improvemen on the Regular barley. This is much earlier, free from rust and an enormous yielder. Will outyield common barley two or three times. It stands up well and seems to be adapted to all kinds of soil. The heads are always filled with good, plump, heavy grains that have a very thin hull.

Per 1b., postpaid, 20c; 50 lbs., $\$ 1.25 ; 100$ lbs., $\$ 2.50$

COMMON BARIEY-We always aim to have a nice, clean stock of good Seed Barley on hand at all times.

Per 1b., postpaid, 15c; 100 lbs., market price.

\section{Flax Seed}

Recleaned for planting.

Per 1b., postpaid, 20c; 100 lbs., $\$ 5.00$

Flax for other purposes.

Per 1b., 20c; 100 1bs., $\$ 4.00$

Grond Flax, for medicinal uses.

$$
\text { Per 1b., 25c }
$$

\section{Idaho Pea or Coffee Berry}

A forage plant, valuable for semi-arid lands. Yields excellent crops of feed for horses, cattle sheep and poultry. The peas, when nicely browned and ground. make an excellent beverage.

Per 1b., postpaid, 25c; 100 Ibs., $\$ 6.00$

\section{Soja Bean}

A very valuable fodder plant, either for feeding green or for the silo. It is a rich food and is unsurpassed for forming flesh. Sow 30 pounds per acre in the spring after the ground becomes warm. Like clover, it improves the soil by drawing nitrogen from the air. Very productive.

Per 1b., postpaid, 25c; 100 lbs., $\$ 9.00$ 


\section{CLOVER AND GRASS SEEDS-Continued}

HUNGARIAN MILIET-A valuable species of warf millet, finer than the Common and Gerlan varieties, but producing a closer stand and re than most other grasses to mature a profable crop, and the hay is a favorite with stock. ow twenty-flve to thirty pounds per acre. An-

er 1b., 25c; 10 to 25 lbs., 7c per 1b.; express or freight, charges collect; 100 lbs., write for price.

WIID RICE (Zizanla Aquatica)-For planting duck ponds. A valuable forage plant; also furishes food for wlld fowl ducks, geese, etc seed an be sown on the borders of lakes, ponds and mall streams and grows very rapidly in one to irds from September on $r$ and affords a refuge for the small fry from the rge fish.

Per lb., postpaid, 35c
Prices on Field Seeds are subject to market changes, but we will always send you full value, whether it be more or less, unless otherwise ordered. Special prices in quantity on request.

\section{Vetches}

SPRING VETCHES (Vicia sativa)-A species of pea grown for stock. Sow broadcast sixty"five to one hundred pounds to the acre, and treat sane as field peas.

Per 1b., 25c; 10 to 25 lbs., 6 c per 1b.; 100 lbs., $\$ 5.00$; by freight or express, charges collect.

SAND, WINTER or RAIRY VITCHES (Viclia villosa) - This variety flourishes well on poor solls. The vines are tall, and furnish a great amount of feed. If cut when full grown. it will start up again, and give a good yield of forage or seed the same season. One hundred pounds to the acre broadcast.

Per $1 \mathrm{~b}, 30 \mathrm{c} ; 10$ to $25 \mathrm{lbs}$. at buyer's expense for freight, 15c lb.; 100 lbs., write for price.

\section{STRAWBERRY PLANTS POPULAR AND BEST WESTERN SORTS}

WILSON-A heary bearer of fine, moderateized brrries; lealing sort for canning.

MAGOON-Iarge, firm and excellent: sub-acid vor: hears hearily: later than the Wilson.

CLARK'S SEEDIING-The best shipper; beries large, firm. delicious; vines bear large crops; especially adapted to dry soil.

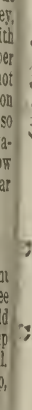

Iinds-

lark's Seedling

Iagoon

Tarshali

iew Oregon, each ioc.

ASPARAGUS.

One-year-old plants-Postpaid, doz., 25c; 50, '5c; 100, \$1.00. By express or freight, doz., 20c; i0, 50c; $100,75 \mathrm{c}$.

Two-year-old plants-Postpaid, doz., 40c; 50 , $31.00 ; 100$. \$1.50. By express or freight, doz., $25 \mathrm{c}$; i0, 75c; $100, \$ 1.00$.

Trite for prices if wanted by the thousand.

\section{HORSE RADISH ROOTS.}

Postpaid, each, 5c; doz., 40c. BJ express or reight, doz., 25c; 100, \$1.50.

PRICE IIST OF PIANTS.

MarshatL-Recommended by Corvallis Experiment Station as being the best all-round strawberry; very large; dark crimson throughout; fine flavor: a fine market and table berry. One local grower says in size, appearance, flavor and sweetness it is superior to the Magoon.

By mail, postpaid.
$100 \quad 1000$ Not less than 500 plants of a kind at the 1000

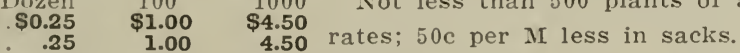

$1.00 \quad 4.50$ rates; $50 \mathrm{c}$ per M less in sacks.

4.50
1.25 60 Special prices on large quantities. State 15.00 amount and kind wanted.

\section{VEGETABLE PLANTS}

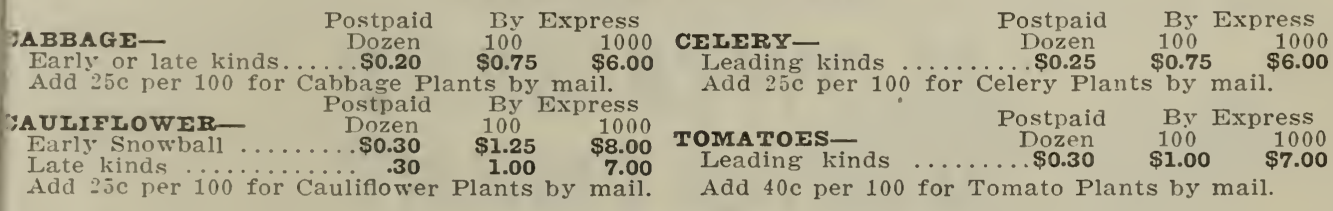

\section{VEGETABLE ROOTS, ETC.}

\section{FRUIT TREES AND BUSHES}

\section{IPPIES-}

Two-year-old

One-year-old 4 ARICOTS-

Two-year-old

4 to 6 feet.............

CRAB APPTES

Nice stock tre

Each. CHERRIES

Two-year-old

$\$ 0.35$

One-year-old.

Each

$\$ 0.50$
Per 100 $\$ 18.00$

15.00

....

Per 100

$\$ 30.00$

25.00

....

Per 100
$\$ 40.00$

$\$ 40.00$
HOP VINES.

Strong roots-Postpaid, each, 5c; doz., 40c. BY express, doz., 25c; $100, \$ 1.50$.

We can make very low prices if wanted by the 1,000 .

Varieties-Mammoth, Giant and Iinnaeus.

One-year-old roots-Postpaid, each, 8c; doz., $75 \mathrm{c}$.

By express or freight. doz., $50 \mathrm{c} ; 100, \$ 3.00$.

Two-year-old roots- Postpaid, each, 15c; doz.,

$\$ 1.50$. By express or freight, doz., 85c; 100, $\$ 6.00$. If wanted in larger quantities, write for special prices. 


\section{FRUIT TREES AND BUSHES-Continued}

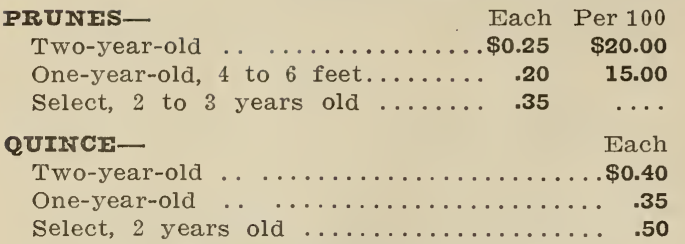

\section{Small Fruits}

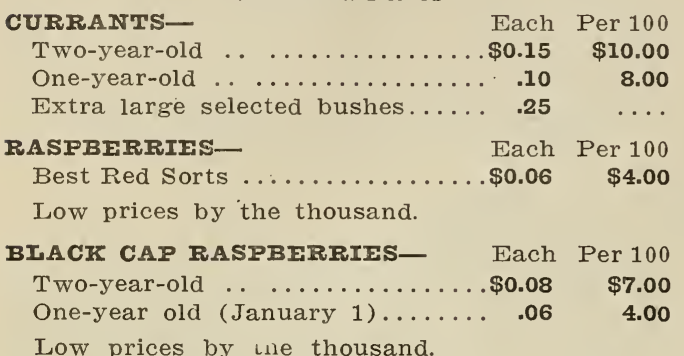

\section{GOOSFBFRRIES-}

Two-year-old ............\$0.10

One-year-old ............. .08

Large selected bushes ........ .15

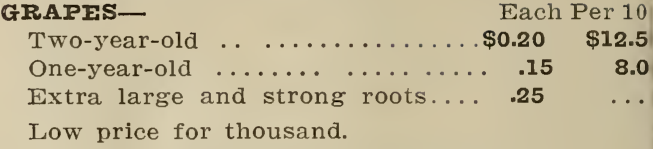

\section{Fruit Tree Seeds}

The following do not produce the same varie ties from seed, but the seedlings are used a stocks on which to graft or bud all our approver varieties.

APPIE-Seeds may be planted in fall. winter or spring. If not planted till spring, the seec should be kept moist during winter. Select deep rich, moist soil, and sow thickly in rows two fee apart. Keep free from weeds.

$$
\text { 1/4. 1b., 20c; 1b., 50c }
$$

PEAR-Plant the same as apple seed, but for growing pear stocks, the ground should always be deep rich, and moist, and the young plants should be cultivated often, to insure a rapic growth the first season, as upon this depends $\$ \mathbf{\$ 8 0}$ their value for stocks. They are budded anc 6.00 grafted the same as apples.

$\ldots$ Oz., 20c; 2 oz., 30c; $1 / 41 b ., 50 c ; 1 b ., \$ 1.50$

\begin{tabular}{l|l|}
\hline FLOWER SEED \\
DEPARTMENT
\end{tabular}

\section{GENERAL DIRECTIONS FOR CULTURE}

Flowers usually succeed best in a sandy loam, made rich with well-rotted manure, which should be made fine and thoroughly mixed with the soil. A soil thus prepared will remain moist and loose, so that flower seeds, which are ger.erally small and delicate, will germinate and grow with vigor.

The mistake is often made of working the soil when too wet, so that in drying it bakes and cracks. The soil should always be dry enough to work up mellow, and crumble when struck with a spade.

If fine seed is to be planted, make the surface even with a piece of board; sow the seeds, anu then carefully sift a little dirt over them, after which water with a watering-pot having a fine rose. Shade from the hot sun until well up. Larger seeds should be planted deeper. A hotbed or cold frame is very convenient to start seeds in, as the temperature and moisture can be so regulated as to make their germination and rapid growth more certain. Most seeds do well if sown in boxes in a sunny window in the house. Plants are usually ready to be transplanted when they have made a growth of two inches. It is a very common mistake to let them stand so close together as to crowd each other, and thus lose much of their beauty. Give each plant plenty of room, according to its habit of growth.

All plants, and especially annuals, exhaust themselves in maturing seed, consequently, to insure the health of the plant, and concentrate its full vigor in the continued production of an abundance of the finest blossoms, the flowers should all be taken from the stem when in full bloom, or at least as soon as the petals begin to wither or fall.

Many annuals, in warm climates, or when taken in or protected during winter, become perennial, with, however, but short lives. 


\section{DESCRIPTIVE LIST OF}

\section{CHOICE FLOWERS}

Worthy of Special Attention, Embracing

ANNUALS, BIENNIALS, PERENNLALS, CLIMBERS AND EVERLASTINGS

All Flower Seeds Sent Free by Mail on Receipt of the Price Placed Opposite Each Variety.

\section{ABRONIA}

Exceedingly pretty trailing plant, producing agrant, verbena-like flowers, that remain in ffective in beds, rockrork, or baskets. The usk should be removed from the seed before lanting. Grows freely in any light, rich soil. Calf-hardy annual.

Mized pirt., 10c.

\section{ABUTILON}

(Flowering Maple)

One of the best perennial flowering plants for the reenhouse and colservatory and thrives outdoors warm climates. The drooping, bell-shaped flows are crimson, vellow, and white, or striped and eined with different colors. If sown early, will Fine mised hybrids, pkt., $25 \mathrm{c}$.
Fine mist the first season.

\section{ACROCIINIUM.}

(Everlasting Flower)

Elegant annual everlastings, producing beautiful laisy-like flowers, rcsembling the rhodanthe. Fine or winter bouquets. Gather when partially opend, and dry in the shade. Height ten to fifteen nches.

Ilbum-Pure Thite

Pkt., 5c vired-All colors

Plkt., 5c

Valuable and well-known plant. Fine for ouquets and useful for beds, borders, ano jot plants. The flowers are graceful tufts of ine petals that remain fresh a long time after beng cut. The plant blooms all summer, and, if protected or potted, and taken indoors, will coninue to bloom all winter. Thrives well during our long, dry California summers. Half-hardy annual; six to eighteen inches high. Mexicanum-Light blue White Dwarf $\ldots \ldots \ldots \ldots \ldots \ldots \ldots$ Pkt., 5c

Pkt., 5c Fine Mixed-All colors ................

\section{AGROSTEMMA}

Strikingly beautiful for beds, ribbons and borders. Its graceful, pink-like flowers remain fresh a long time after being cut, and are very handsome in bouquets. Thrives in any good soil.

Coronaria (Rose Campion)-Perennial)..Pkt., 5c Coeli Rosa (Rose of reaven)-Annual....Pkt., 5c

\section{AGROSTIS}

(Ornamental Grass)

A hardy annual ornamental grass, delicate and graceful; very beautiful and effective when mixed with everlasting flowers in winter bouquets. Fifteen to eighteen inches high.

Nebulosa-One of the most graceful.....Pkt., 5c Pulchella - Very fine and delicate......... Pkt., 5c

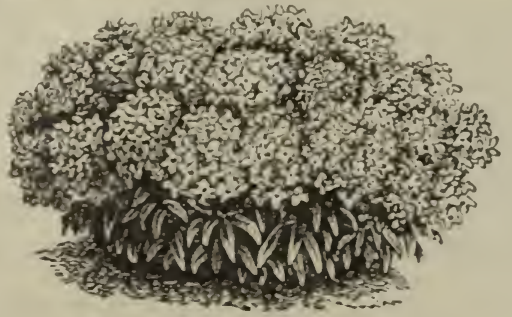

AIYSSUM

The Alyssums are well-known, hardy plants of easy cultivation, effective in beds, and especially fine for borders and edgings. The White Sweet Alyssum possesses a delicate, agreeable frag- rance, and is very nopular for bouquets. They all free bloomers, especially if the llowers are removed before they begin to fade li taken in and protected, they will bloom all winter.

White Sweet-Very fragrant; useful in

Golden Alyssum (Sitxatile) The golden yellow flowers are desirable for rockwork and masses in beds. Hardy perennial

Plst., 5c

\section{AMARANTEUS}

Graceful, easily-grown ornumental foliage plants, for the flower garden or comservatory. The colors are brighter if planted in not too rich soil, and are very handsome and effective contrasted with other ornamental foliage plants. Half-hardy annuals.

Caudatus (Love Lies Bleeding)-Drooping flowers .................... $5 \mathrm{c}$ Cruentus (Prince's Feather)-Erect flow-

Tri-Color (Joseph's Coat) - Beautifully variegated, foliage scarlet, yellow and green

\section{ARISTOLOCHIA-SIPHO}

(Dutchman's Pipe)

A rapid-growing and most attractive climber, with curious, horn-shaped flowers, resembling syphon. Very effective when trained against a house or piazza, or for covering an arbor. Hardy perennial

Pkt., $10 \mathrm{c}$

\section{ASPERUIA}

A dwarf, hardy annual, bearing a profusion of delicate, lavender-colored flowers. Fragrant and desirable for bouquets. Fine for borders. Pkt., 5c

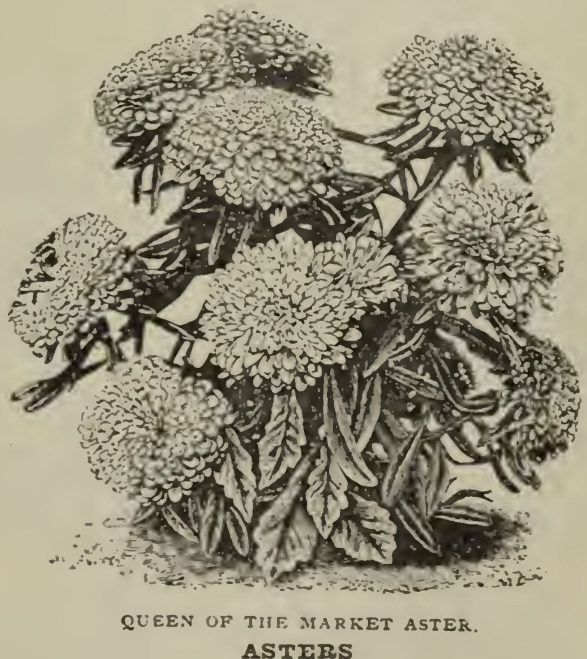

A splendid class of plants, which for a late summer and fall blooming anual has no superior. producing a profusion of flowers of a great variety of rich colors and shades, of varied and beautiful form. The late flowers are usually the best, and, to sustain the plant, it should have rich soil and abundant moisture.

Truffaut's Paeony Flowered Perfection-

Full flower, perfect in form. Choice

mixed

Pkt., 100 


\section{DESCRIPTIVE LIST OF CHOICE FLOWERS-Continued}

\section{Asters}

New Rose-Ten finest varieties, mixed..Pkt., 10c Dwarf Bouquet-Grows a mass of choice

flowers. Fine for beds and borders.

Splendid mixed ..................... 10c

Victoria - Very handsome, well-formed

plant. Flowers of beautiful globular

form. Twelve splendid varieties,

mixed ........................ 10c

washington-Extra double, large flowering, vigorous growth, delicate colors. Extra mixed ....................... 15c

Dwarf Chrysanthemum-Dwarf, compact habit. Large flowers. Very free blooming. Mixed ................ $10 \mathrm{c}$

Japanese-A very distinct and attractive class. The plants are vigorous, producing large, beautiful flowers, having long, tubular and twisted petals............ Pkt.

German Quilled-Large flowers of brilliant colors, freely produced. All colors mixed

. . .................... 5c

mixed ...... Pkt., 10c

Snow White-Desirable for bridal or funeral decoration .............. Pkt., 10c

Fine Mixed-Assorted varieties and colors. In great variety............. Pkt., 10c

\section{BACHEIOR'S BUTTON}

(Centaurea Cyanus)

A hardy annual, easily cultivated. Has recently been greatly improved, and now produces handsome flowers of a great variety of rich colors. Borne on tall, branching stems, with but little foliage. Striking and handsome.

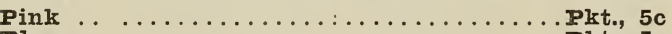

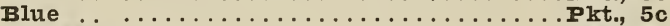

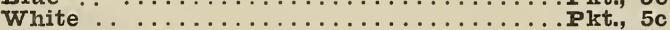

Choice inixed ................

\section{BAIIOON VINE}

(Cardiospermum-Love in a Puff)

A climbing annual, having rather inferior flowers, which. however, are followed by curious puffs or balls that are quite handsome.

$$
\text { Pkt., 5c }
$$

\section{BATSAM}

(Ladies' Slipper-Touch-Me-Not)

Exceedingly attractive and handsome plants, growing either in the conservatory or outdoors, and producing masses of various-colored flowers. No plant better repays the attention bestowed upon it. The soil should be very rich and free. The plants can be pinched back, so as to form bushes of any desired shape. Hardy annual, easily grown.

Double White-Extra choice.........Pkt., 10c Camellia Flowered, Double-Finest mixed Pkt., 10c Rose Flowered-Double mixed.......... Pkt.,. 10 Double Dwarf-Mixed . . ................ $5 c$ Double Tall-Mixed ...................... 5c

\section{BARTONIA}

Showy annual, bearing brilliant, metallic-yellow flowers that are large and gaudy. They require abundant moisture, and will not bear transplanting.

Golden Bartonia-Very fine

Pkt., $5 c$

\section{BRIZA or QUAKING GRASS}

A handsome and useful ornamental grass Bears graceful pods on slender stems, which quiver with the slightest motion. Fine for winter bouquets. Hardy annual.

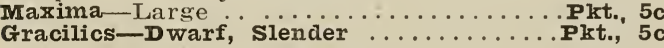

Pkt., $5 c$

\section{BROWAIITA}

Handsome, free-flowering annual. Covered ali summer with bright, rich blue and white flowers. Worthy of more general cultivation. Eighteen inches high. Mixed

\section{BRYONOPSIS}

An annual ornamental climbing gourd, bearing green fruit, which, as the summer advances, changes in color to bright scarlet, striped with white. Tender annual, of rapid growth and great beauty.

\section{Pkt., 5c \\ CACAIIA}

(Tassel Flower)

The cacalias, known by some as Flora's Paint Brush, produce scarlet and yellow tassel-shaped flowers during a great part of the summer. Hardy annual.

Mixed-All colors ................... 5c

\section{CAIANDRINIA}

Pretty, dwarf-growing plants for massinz. Succeed well in a light, rich soil and sunny exposure. They are annuals, but become perennial in warm climates, or if protected.

Grandiflora-Rosy lilac ............ Pkt., 5c Speciosa Alba-Dwarf. Very fine.......... Pkt., 5c

\section{CAICEOIARIA}

A very handsome and much-admired perennial, desirable either for the greenhouse or outdoor culture, producing a profusion of beautifully spotted and tigered flowers of unique form. They flower best in a rich, sandy loam, and can be propagated from either seed or cuttings. Some varieties are shrubby in appearance.

Grandiflora-Large flowered, self-colored,

splendid, robust, profuse bloomers.... Pkt., 25c Iybrida-Tigered and spotted, brilliant.

Finest mixture .............. Pkt., 25c

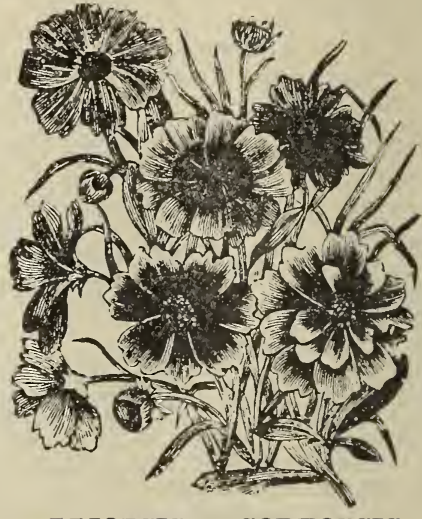

CAIIIOPSIS or COREOPSIS

A hardy annual, very showy and attractive. It is branching, and produces a mass of bright flowers, all shades of yellow, orange, and gold, with a dark, velvety center. Sow where it is to remain, and cut the flowers when in full bloom. Choice Mixed ........................ 5c

\section{CAIIIRHOE}

A charming genus of hardy, annual, summerblooming plants. Commences to bloom when only six inches high, and continues to yield a succession of attractive flowers throughout the summer and autumn.

Pedata-Dark red ............... Pkt., 5c Nana Compacta-New. Very dwarf and

compact. A profuse bloomer.........Pkt., 5c verticillata-A trailing variety, bearing a

profusion of crimson-purple flowers....Pkt., 5c

CAMPANUIA MFDIUM-See Canterbury Bell.

\section{CANARY BIRD FLOWER}

('Tropoeolum Canariense.)

One of the best climbing plants, with graceful foliage of a delicate shade of green, and small, yellow blossoms, which, when half expanded, has a fancied resemblance to a canary bird. Halfhardy annual, of rapid growth.

Yellow ......................... 5c 


\section{DESCRIPTIVE LIST OF CHOICE FLOWERS-Continued \\ CANDYTUTT \\ CENTAUREA}

(Iberis)

Well-known, hardy annual, thriving almost anyhere and producing a profusion of bright, cheerful flowers. Very useful for cut flowers, borders, ribbons, or for conservatory decoration Great improvement has been.made in the colors during the last few years.

purple .............................. 5c

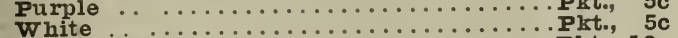
Dwarf inixed-Compact habit .................... 10c Fine Mired-All colors ..................... 5c

\section{CANTERBURY BEII}

(Campanula Medium)

Very ornamental garden plants. Their large bell-shaped flowers are borne on tall, gracefu stalks, and are produced freely throughout the summer. Hardy biennials. Very showy and attractive. Double and Single-Blue $\ldots \ldots \ldots \ldots \ldots \ldots$ Pkt., 10c
Double and Single - White $\ldots \ldots \ldots \ldots$ Pkt., 10c Double and single-Mixed ............

\section{CARDIOSPERMUM-See Balloon Vine.}

\section{CARNATIONS}

(Dianthus Caryophyllus)

Universally admired, deliciously fragrant, popular favorite. The largest and finest of the family of which the Pink and Sweet William are wellknown members. Unsurpassed for richness and delicacy of form and color. Young plants produce the finest flowers, and fresh seed should be sown every year or two. Half-hardy perennial.

Early Flowering Vienna-Extra mixed..Pkt., 10c Double Red-A splendid variety for flor-

ists ............................... 15c

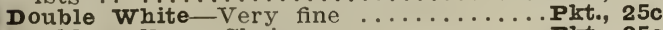
Double Yellow-Choice ............................. 25c Carnation Marguerite-In some of its habits this flower is a great improvement over all other varieties of carnations. The seed will give good flowering plants in four to five months. The flowers are large, very fragrant; borne in abundance and in a great variety

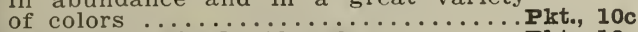
Fine Double IMized-All colors..........Plst., 10c Extra Choice Double Mixed-From superb varieties, including Flakes, Bizarres, and Selves ........................... 25c

\section{CASTOR BEAN}

(Ricinus)

A highly-ornamental genus of half-hardy annual of stately growth, and large leaves of bronze or glossy green. By planting either singly or in groups, a striking effect is produced on lawns or pleasure grounds.

Sanguineus-Briliant scarlet ......... Pkt., 5c Borboniensis Arboreus-The largest variety. Tall and stately

Mixed-Best varieties

Pkt., $5 \mathrm{c}$

\section{CATCHFIY}

(Silene)

A hardy annual, yielding for a long time a profusion of umbels of bright-colored flowers. The plant is covered with a glutinous moisture, to which flies adhere; hence its name.

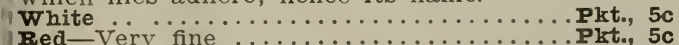
Red-Very fine $\ldots \ldots \ldots \ldots \ldots \ldots \ldots \ldots \ldots \ldots$ Pkt., 5c
Fine Mixed-All colors $\ldots \ldots \ldots \ldots \ldots \ldots$

CEIOSIA

Graceful, free-blooming. half-hardy annuals, producing a profusion of beautiful, featery flowers. Of the same family as the Cockscomb, but producing their flowers in plumes instead of combs. They can be grown in pots for the conservatory or greenhouse, or planted out after danger of frost is past.

Plumosa-Mixed colors of great brilliancy .................... Pkt., 25c Argentea-Bears long, silver-white plumes which, when dried, are fine for winter bouquets ......................... 10c
(Dusty Miller)

This genus embraces some of the finest silver foliage plants in cultivation, and, when arranged side by side, in figures or in borders, with dark and other ornamental foliage plants, rivals in interest and beauty the finest flowers. Some also produce beautiful and attractive flowers. Sow early, under cover, or later in open ground, and transplant when two inches high. Annuals, biennials, and perennials.

Candidissima-The finest; handsome silver foliage. Leaves deeply indented. Half-hardy perennial .................. 15c Gymnocarpa-Foliage silver gray, drooping, graceful. Perennial ............. 10kt., 10c Americana-Blue flowers. Annuals.....Pkt., 5c Moschata (Sweet Sultan)-Blue, yellow, and white mixed $\ldots \ldots \ldots \ldots \ldots \ldots$. Pkt., 5c

\section{CHRYSANTHEMUM}

The annual chrysanthemums are rapidly coming to the front, both as greenhouse and garden plants. They should not, however, be confoundea with the Japanese perennial kinds that are being so widely introduced. The annuals have recently been greatly improved, and we feel confident that they will not suffer by comparison with their foreign namesakes. Our list includes choice varieties.

Frutescens Marguerite, or Paris Daisy-

White and yellow flowers............Pkt.,.10c

Burridgeanum (Iord Beaconsfield)-

White and rose. Very fine.............. 5ct.,

venustum-White, crimson center.......Pkt., 10c

Japonicum-Extra choice mixed, from the

finest Japanese varieties. Perennial... Pkt., 25c

Double White . . . . . . . . . 50

Double Yellow ................ Pkt., 5c

Eclipse-Tricolor. Purplish scarlet,

brown, and yellow. Choice....... Pkt., 5c

Mixed-Very choice double............Pkt., 50

\section{CINERARIA}

Well-known, free-flowering greenhouse plants. The flowers are very brilliant, and of great variety of colors. One of the brightest and most valuable of early spring flowers. They can be planted out when the weather becomes settled, and propagate readily by dividing the roots. Perennial.

Fybrida-Double. Mixed. Extra choice:Pkt., 25c Hybrida Nana-Mixed. Dwarf. Free

flowering ...................... 25c

\section{CIARIIA}

Handsome, free-flowering annuals of easy cultivation. Produce a fine effect massed in beds. Bear both single and double flowers, which are very bright and attractive.

Finest Mixed .................... 5 c

\section{CIEMATIS}

Well-known, tall-climbing, perennial plants, of great beauty and elegance. Very desirable for arbors, latticework, and trellises, on account of their rapid growth.

Flammula Covered with handsome tufts

of white flowers ................ $5 \mathrm{c}$ Mixed Hybrids-All the choice varieties. Pkt., 100 CIOVER, Sweet Scented

(Trifolium Suaveolens)

A low-growing, hardy annual, of easy cultivation, highly prized for its delicately-scented foliage and flowers. Charming for beds and borders ............................ 10c

\section{COBAEA SCANDENS}

A handsome, rapid-growing, climbing perennial plant, having large, bell-shaped flowers, beautiful foliage, and peculiarly delicate and curious tendrils.

Tender Perennial ............... Pkt., 5c 


\section{DESCRIPTIVE LIST OF CHOICE FLOWERS - Continued}

\section{COCKSCOMB}

(Celosia Cristata)

Very ornamental and interesting plants, producing crest-like flowers of great beauty, resembling a cock's comb. The tufts of some varieties grow to an enormous size, and their feathery, graceful appearance and brilliant colors render them very attractive. Half-hardy annuals, of easy cultivation.

Variegated-Combs beautifully variegated with crimson and gold............. Pkt., 10c Japan-New and magnificent combs, massive and fine ..................... 10c Dwarf Mixed-Finest dwarf varieties; combs as large as the taller sorts.... Pkt., 10c Tall IMixed-The best tall varieties....... Pkt., 10c

\section{COIUMAINE}

\section{(Aquilegia)}

Commonly known as the honeysuckle. A hardy perennial, producing handsome flowers, of unique form and many bright and attractive colors. They are hardy, and the seed may be sown as soon as the ground can be prepared. Can be increased by dividing the roots.

Chrysantha-Golden yellow. Fine .....Pkt., 10c Double White-Very handsome ............ Plt., 10c Mixed-Best double and single varieties.

Very fine ..................... 5 c

\section{cosmos.}

Also known as Mexican Dahlia. A tall, branching annual, of easy cultivation, having delicate, needle-shaped foliage. The flowers are produced in profusion, and are usually bright and attractive, resembling single dahlias. Colors range through rose and purple to pure white. A desirable and favorite plant.

Hybrida Giant IMized.

Dawn-An early-flowering strain; flowers

pure white .................. 5 .

CowsIIP.

(Dodecatheon Meadia)

A low-growing hardy perennial, blooming very early in spring. It is of easy cultivation, and can be multiplied by dividing the roots. A popular and very desirable border plant.

Choice Irixed

\section{CYPRESS VINE.}

(Ipomoea Quamoclit)

A climbing annual of rapid growth, having handsome, fern-like foliage and a profusion of bright, attractive flowers. When furnished a suitable support, it becomes very ornamental and showy. Plant the seeds where they are to remain as soon as the ground becomes thoroughly warmed.

White

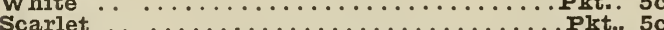

Mixed-Ail colors $\ldots \ldots \ldots \ldots \ldots \ldots \ldots \ldots$ Plt., 5 c

\section{DAISY.}

(Bellis Perennis)

A well-known, half-hardy perennial, blooming early in spring. Very desirable for borders. Sow early, under cover if necessary, and transplant, when well started, to a moist, shaded place. They soon spread, and the roots can be divided.

Double White $\ldots \ldots \ldots \ldots \ldots \ldots \ldots \ldots \ldots \ldots \ldots \ldots$ Pkt., 10c
Double Mixed $\ldots \ldots \ldots \ldots \ldots \ldots \ldots$

DATURA.

(Trumpet Flower.)

Ornamental, half-hardy, perennial plants, producing large, sweet-scented, trumpet-shaped flowers. Succeeds in almost any soil. The roots may be preserved over winter, like dahlias.

Double Inixed-All colors.............. Plst. 5c

\section{FSCHSCHOLTZIA}

(California Poppy.)

A showy, free-flowering genus of plants, bearing handsome, graceful foliage and flowers of the richest colors. They bloom very early, and should be planted as soon as the ground can be prepared where they are to remain, as they will not bear transplanting. Hardy annual, thriving best in light, warm soil.

Califormia-Yellow, orange center......Pkt., 5c IVandarin-The colors of the petals are

orange inside, brilliant scarlet outside.

Choice $\ldots \ldots \ldots \ldots \ldots \ldots \ldots \ldots$. . . 50 Mixed-Ali colors. Very fine............ Pkt, 5c Mammoth Fackage California Poppy.....Pkt., 10c

\section{FEVERFE.}

(Matricaria Capensis)

A free-flowering, ornamental, hardy annual, desirable for bedding or pot culture. It produces very double white flowers. Sow early, and plant out into pots or open ground.

Best Double white.................. 10 c

\section{FORGFT-ME-NOT}

(Myosotis)

Low-growing, popular, perennial plants, blooming the first season, if sown in the fall or very early in the spring. Fine for borders and edgings. A constant and profuse bloomer. Flowers mostly blue, with white or yellow center.

Dissitiflora-Deep blue ............. $10 \mathrm{c}$ Falustris-Light blue ............... Mixed-Choice, all shades .............. 10kt., 10c

\section{FOUR O'CIOCK}

(Mirabis-Marvel of Peru)

Also called Beauty of Night. A well-known hardy annual, growing luxuriantly in any ordinary soil, and bearing a profusion of bright, handsome flowers of various colors, shades, and markings, from scarlet, through pink, to white, and from salmon, through orange, gold, and straw, to white. Each plant produces self-colored and variegated flowers. Some varieties are fragrant, and some have ornamental foilage. They have recently been greatly improved, and are becoming very popular. They are tall and branching, and should have plenty of room.

Choice Mixed-Self-colored and varie-

gated, in great variety ............. Pkt., 5

\section{FOX GIOVI}

\section{(Digitalis)}

A tall-growing biennial, with large leaves, and spikes of vari-colored and spotted flowers. Greatly improved of late, and now a really magnificent plant.

Extra Mixed . Pkt., $5 c$

\section{GAIIIARDIA}

A fine-looking plant, flowering in great profusion and brilliancy the entire season. Hardy annual, becoming perennial in warm climates.

Grandiflora-Choice mixed. All colors...Plt., 5c Picta-Iorenziana-Magnificent flowers, resembling some varieties of Japanese chrysanthemums. Various colors and

shades. Very desirable .................. 5c

\section{GTOBE AMARANTH}

(Gomphrena)

Extremely handsome everlastings. The flowers, which should not be cut till fully matured, will keep for years, and are fine for fresh-cut flowers, and almost indispensable for winter bouquets. Half-hardy annual.

Purple . . . . . . . . . . . . . . . Pkt., 50

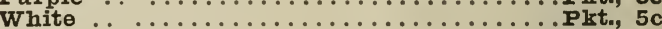
Mrixed-Ali colors $\ldots \ldots \ldots \ldots \ldots \ldots \ldots \ldots$ Pkt, 50 


\section{DESCRIPTIVE LIST OF CHOICE FLOWERS-Continued}

\section{GODETIA}

Beautiful plants, of easy cultivation, producing large, showy flowers. Hardy annuals, of dwarf habit, recently much improved.

Best Varieties, Mixed

\section{GOLDEN FEATHER}

(Pyrethrum Parthenifolium Aureum)

One of the most desirable border plants in cultivation. Foliage delicate, beautifully fringed and of a bright golden tint. The flowers are insignificant, and, to secure the most elegant borders, cut out the spikes on which the buds are formed as fast as they appear. Hardy perennial, of easy cultivation .............. Pkt., 50

\section{GOURDS}

\section{(Cucurbita)}

Extremely rapid-growing, trailing annuals, of easy cultivation. Useful for walls, fences, anc unsightly places. The fruit of many of the varieties is elegant and curious, and some of them may be made useful as dippers, bottles, and other articles.

\section{Orange}

Egg-Shaped-Thite, very useful for nestggs. Does not crack or decay .......Pkt., $5 c$ Dipper or Bottle - Useful and handsome..Pkt., 5c Hercules' Club-Club-shaped. Large and long-Seed saved from the most useful elegant and unique varieties ..........

\section{GYPSOPHILA}

Delicate, useful, free-flowering little plants, for baskets, edgings, or bouquets. Annual and perennial.

Muralis-Pink. Hardy annual.......... Pkt., 5c Paniculata-Thite. Best for winter bou-

quets. Hardy perennial ............ Pkt., 5c

\section{HEIICHRYSUM}

(Eternal Flower)

Very ornamental, hardy annual for the garden, and one of the best of all for winter bouquets. Gather when partially opened, and dry in the shade. Will thrive in any good garden soil.

White-Mixed, dwarf and tall..........Pkt., 5c Mixed-Dwarf and tall. All colors. Very

elegant ....................... 5 .

\section{HIBISCUS}

Fine, showy, hardy annual, two feet high, with glossy leaves and large, brilliant flowers. In bloom throughout the entire season, and, if potted and removed indoors, will bloom all winter. Of easy cultivation.

Extra Mixed

Pkt., 5c

\section{HOLIYHOCK}

(Althea)

More success has been attained in improving the hollyhock than almost any other flower, the double varieties being now almost as perfect as camellias, and quite as varied and brilliant in color. Their majestic stalks, crowded on all sides with magnificent flowers, are a sight not soon to be forgotten. Our seed is saved from a very large collection of the best strains. Hardy perennial, six feet high, of easy cultivation.

Double Yellow-Choice .............. Pkt., 10c Double white Very large ............................ 10c Double scarlet-Superb ............................ 10c Double Choice Mixed-Ail colors and

many shades. Very fine ........... Pkt., .5c

\section{FYACINTI BEAN}

(Dolichos)

Rapid-growing, ornamental, climbing annuals, bearing clusters of beautiful purple and white flowers, followed by highly ornamental seed pods. Plant where they are to remain, as they do not bear transplanting.

Giganteus-Tall-growing; large, purple

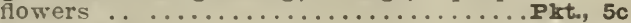
Iablab-Mixed Pl.t., 5c

\section{IPOMOEA.}

One of the most beautiful climbing plants in cultivation, for the greenhouse or sheltered situations outdoors. It can be planted alone, or is very effective in combination with other vining plants. It belongs to the same family as the morning glory. Flowers are of the brightest colors. Tender annual; easily cultivated.

Bona Nox-Large, fragrant, violet-blue flowers, opening toward evening, the name meaning Good night ................. 5c

Limbata Elegantissima-Rich, purple cen-

ter, margined with white ................ 5c Fine Mixed-All colors .................. 5kt.

\section{IPOMOPSIS}

\section{(Standing or Tree Cypress)}

Beautiful plants, with fine, feathery foliage and long spikes of dazzling orange and scarlet flowers. Tery effective for conservatory or outdoor decoration. Prefers a dry, warm situation. Halfhardy perennial.

Mixed

Plet., 5c

JERUSAIFM CARRRY-See Solanum Capsicastrum.

\section{KAUIFUSSIA}

A low-growing plant, which covers itself with a mass of brilliant flowers of many intense colors. In shape and appearance it resembles the Dwarf Aster. Hardy annual, six inches high, easily cultivated.

Mixed-All colors Plet., $5 c$

\section{IAGURUS-See Hare's Tail Grass.}

\section{IANTANA}

A free-flowering, shrubby plant, suitable for outdoor or pot culture. The flowers emit an agreeable odor, and are of many shades of purple, orange, and white. Half-hardy perennial, two feet high.

Finest Hybrids-Mixed ............ Pkt, 5c

\section{IARKSPUR}

(Delphinium)

A very ornamental class of profuse-blooming plants. Their tall spikes of many-colored flowers produce a striking effect when planted in groups. They are very hardy, and the seed may be sown as soon as the ground can be prepared. The perennials can be multiplied by dividing the roots. Height one to three feet; annuals and perennials noted.

Dwarf Rocket Mixed ................ $5 \mathrm{c}$ Tall Stock-Flowered-Mixed. Perennial. . Pkt., 5c Bismark-Robust habit, stock flowered red striped. Very fine. Perennial...Pkt., 10c Candelabrum-Formed - Stalks branching

like a candelabrum. Annual ......... Pkt., 10c Bee-Elatum. Mixed. Perennial......... Pkt. 5c Nudicaule-Scarlet. Perennial .........Pst., 10c Formosum-Dark blue. Perennial .....Pkt., 5c Mrized-Annuals. All colors ............. 5kt., 5c

\section{IINUM}

(Scarlet Flax)

Beautiful, slender, free-flowering plants of many bright colors. Hardy annuals and perennials, eighteen inches high. They flower well in any ordinary soil, and are very showy. 


\section{DESCRIPTIVE LIST OF CHOICE FLOWERS---Continued}

\section{IOBELIA}

Delicate, low-growing, annual plants, of the greatest value for borders, ribbons, edgings, rockwork, and hanging baskets. The seed is very fine, and can be sown early in boxes, or a little later in open ground, and the plants transplanted. Crystal Palace Compacta-Very dwarf. Gracilis-Biue. ${ }_{\text {Spreading. }}$ Fine for frt., $^{5}$ baskets ................... 5 . Alba-Pure white ............ Pkt., 10c Finest Mixed ................ Plkt., 10c

\section{IUPIN}

(Lupinus)

A genus of very desirable shrubby plants, growing from a few inches to several feet in height, bearing long spikes of various-colored flowers. They can be pruned into handsome shapes. Annual and perennial.

Cruikshanksi-Dark blue annual ........Pkt., 5c Mixed-Best annual varieties of all colors Plt., 5c

\section{MARIGOTD}

(Calendula and Tagetes)

The marigolds are well-known, hardy annuals, of easy cultivation, varying in height from the French, of a few inches high, to the African, two feet. They have responded to the florist's efforts, and are now really magnificent flowers. The colors are gold, orange, and varying shades of these colors. Some are densely double, large, regular in form, and very fine. They flower early, and continue to bloom all summer.

Meteor, Calendula-Flowers striped dark

and light orange. Double. Very fine..Pkt., 5c Prince of Orange, Calendula-Choice......Pkt., 5c Double Mized, Calendula - All shades.

Choice $\ldots \ldots \ldots \ldots \ldots \ldots \ldots$.............. $5 c$ African, Tagetes-Double mixed ..........Pkt., 5c

\section{IMAURANDIA}

A graceful, tender, perennial climber, for the greenhouse, conservatory, or flower garden. Blooms the first season from seed. The flowers resemble those of the foxglove and are produced abundantly.

Finest Mixed Colors

Plkt., 10c

\section{MIGNONETTE}

(Reseda)

Well-known hardy annual, varying in height from eight to eighteen inches. Easily grown. Produces abundant spikes of exceedingly fragrant flowers of several different colors. The flowers should all be cut when in full bloom, as the plant soon exhausts itself in maturing seed. By sowing at intervals, flowers can be had during the whole season. No garden is complete without the following choice varieties:-

Resada Odorata Grandiflora-The wellknown large-flowering Sweet Mignon-

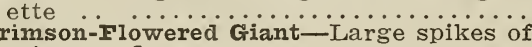
crimson flowers

Parson's New white-New and valuable... Pkt. $5 c$ New Fybrid Spiral-A strong grower, abundant bloomer, and very fragrant..Pkt., 5c Golden Queen-Very fine, new variety, with flowers of a golden hue. Highly effective

Pkt., 5c

\section{MIMUIUS}

(Monkey Flower)

Extremely handsome plant, with large, brilliant, curiously spotted and striped flowers. Sow in the fall for early-flowering greenhouse and conservatory plants, and early in the spring for summer blooming. They all like damp, shady situations. Hardy annuals and half-hardy perennials. Fybidus Tigrinus-MIost beautiful spot-

ted blotched varieties. Mixed ........Pkt., 10c Hybridus Tigrinus Flore Pleno-Beautiful, double-spotted varieties. Mixed..Pkt., 10c

\section{MOON FLOWER}

(Ipomoea Grandiflora)

One of the most rapid-growing annuals in cultivation, covering an arbor, trellis, or latticework twenty feet high in eight or ten weeks. The flowers are large, of a waxy white appearance, and very showy. They open out on cloudy days and in the evenings.

Plrt., 15c

\section{MORNING GIORY}

(Convolvulus Major and Minor)

The tall varieties are popular, well-known, rapid-growing climbers of the easiest cultivation. Valuable in every garden for trailing on fences, arbors, and verandas. The minor or dwarf varieties flower very freely, and do not require support.

Blue-Tall

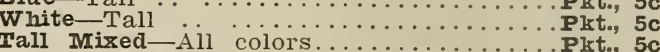

Pkt., 5c Dwarf Mixed-Convolvulus Minor. Ail colors ... ....................... $5 c$

Giant Japanese ivorning Glory-Flowers of immense size, with an almost end-

less variety of color and markings.....Pkt., 5c

\section{MUST PIANT}

(Mimulus Moschatus)

Cultivated on account of its rich, musky odor. Annual, becoming perennial indoors and in warm climates. Should have a rich soil and ample moisture.

\section{Pkt., 10c \\ NASTURTUM}

(Tropoeolum)

Both the leaves and flowers of the Common Tall Nasturtium are very handsome for table decorations. The leaves are also used, when young, as salad, and the seeds, gathered while green and tender, are esteemed by many for pickels. (See Vegetable List.) The Lobbianum varieties are superior to the common sorts when desired for ornamental purposes only. The flowers are larger, more compact, richer, and more varied in color, and are produced more abundantly; they contrast charmingly with the bright, clean, iuxuriant foliage. Fragments of the vine, cut and placed in vases, will remain fresh, and even bloom, for many days. The dwarf varieties have also recently been greatly improved, and are now among the most attractive bedding and border plants. All nasturtiums are rapid growers, flowering best where the soil is not too rich. Hardy annuals, of easy cultivation, the tall varieties growing five to ten feet high.

\section{Tall Varieties}

(Tropoeolum Lobbianum)

Spitfire-Bright scarlet ........... Pkt., 5c Carmine .. ................. Plkt., 5c

IKing of the Blacks $\ldots \ldots \ldots \ldots \ldots \ldots \ldots$ Plkt., $5 c$

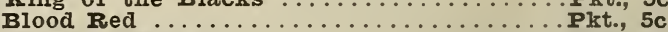

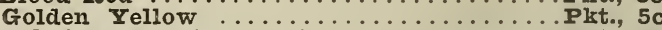
Iobbianum-Finest mixed .................. $5 c$ Irammoth Package Tall Mised Varieties.Plkt., 10c Dwarf Varieties

(Tropoeolum Minor)

Pearl white ................. Pkt., $5 c$ Dark Crimson .................... $5 c$ Golden King-Fine .............. Pkt., 5c Empress of India ........................ $5 c$ Dwarf IVixed-All colors . . . . . . . . .

\section{NICOTIANA}

\section{(Affinis)}

A rery showy plant, producing pure white star-shaped flowers of delicious perfume. Taken up in the fall, cut back, and potted, will bloom freely all winter. Half-hardy annual, three feet high ................... Pkt., 5c 


\section{DESCRIPTIVE LIST OF CHOICE FLOWERS-.-Continued}

\section{NOIANA}

A trailer of much beauty, for rockwork, vases, and baskets. The flowers are showy, and produced very freely. Hardy annual. Mixed.

Pkt., $5 c$

\section{PAEONY}

(Herbacea Chinensis)

An exceedingly handsome perennial, producing magnificent, large flowers, that bloom early in spring. They are as double and varied in color as the finest poppies, which they somewhat resemble. The flowers are formed on single stalks, that rise just above a mass of handsome foliage, and are very attractive. The seed should be sown early, and the bulbs transplanted the following spring, when they will bloom.

Choice Mrixed Double-From a splendid collection .. ................ 25c

\section{PAMPAS GRASS}

(Gynerium Argenteum)

A noble ornamental grass, easily grown from seed, producing majestic plumes, that are inimitable for winter decoration. When well dried, they must be taken by the stalk and thoroughly shaken to bring out their beautiful plume-like appearance. Half-hardy perennial, ten feet high.

Pkt., 5c

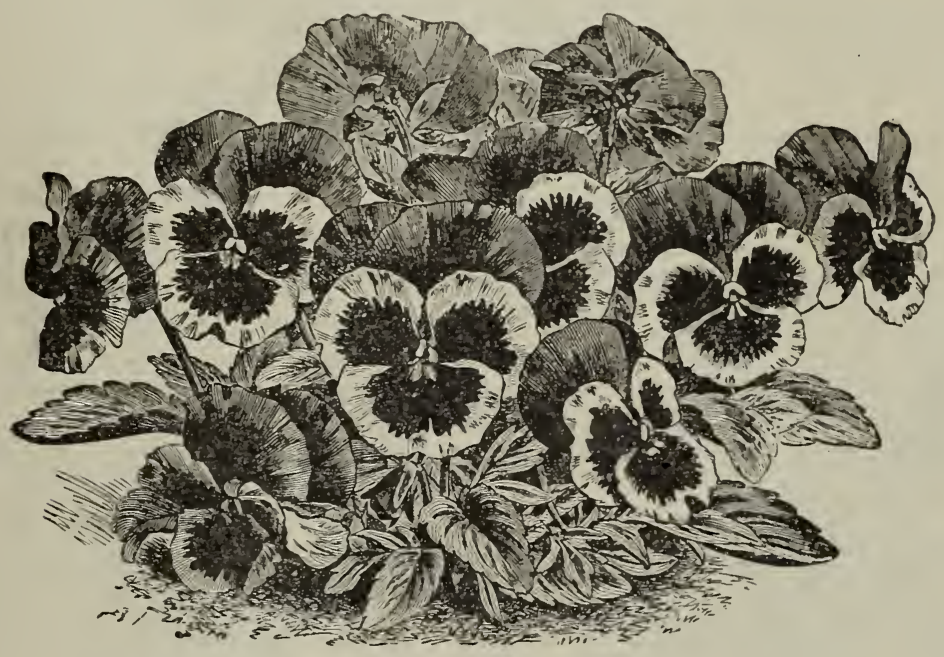

PANSY.

The pansy is one of the most popular of all annual flowers, and is justly held in the highest esteem. It furnishes a profusion of bright, showy flowers of a great variety of rich colors, shades, and markings, throughout the entire season, the flowers remaining perfect a long time. It should have the richest soil, abundant moisture, and a shaded locality. The following is a list of choice varieties.

Azure Blue ....................... 10c Emperor William-Indigo; dark center. . Pkt., 10c King of the Blacks-Velvety black .....Pkt., 10c Mahogany Colored-One of the very best Pkt., 10c Odier-New French blotched ..........Pkt., 15c French Iarge Flowering-Mixed.......Pkt., 10c Lord Beaconsfield-Purple, shading to

light blue. Large and fine .. Pkt., 10c Pure Yellow ......................... 10c Snow Queen-Pure White ...........Pkt., 10c Trimardeau-The flowers of this variety are the largest of any pansy yet produced, and for variety and beauty of marking, brilliance of color, and sta- bility, have no superior .......... Pkt., 10c Fine Mised .................... 5 .

\section{PASSION FIOWER}

(Passiflora)

A family of climbers, bearing a variety of interesting and beautiful flowers. Of tropical origin, it is peculiarly adapted to the warm valleys of the Pacific Coast and the Southern States. Halfhardy perennial, of easy cultivation.

Coerulea - Handsome blue and white

flowers ................... Pkt., 10c Coerulea-Choice mixed ..........Pkt., 20c

\section{PENTSTEMON}

Beautiful, hardy perennial, herbaceous plants, with extremely brilliant blooms. A good bed of pentstemons once seen will not soon be forgotten. Their bell-shaped flowers are borne on long spikes, and are produced abundantly all summer. Varieties differ in growth from six inches to three feet.

Fine Mixed-All colors. Very showy...Pkt., 100 


\section{DESCRIPTIVE LIST OF CHOICE FLOWERS--.-Continued}

\section{PIRIITA}

(Nankinensis)

Ornamental foliage plant, for edging and ribbon bedding; very easily cultivated. Color blackish purple. Very striking when planted with Centaureas and other silvery and light ornamental foliage plants. Hardy annual; height ten to eighteen inches.

Best Mixed

\section{PFTUNIA}

Too much can not be said in praise of the petunia as a bedding plant. Our clear, bright summers seem to bring out its best qualities. During the whole season it is covered with large, showy blossoms, which are always bright and fresh, in spite of heat and drought. The flowers are of an almost infinite variety of colors and markings, and quite as varied in form; large and small, fringed and plain, double and single. Hardy annual, varying in height from nine to eighteen inches.

Double Mixed-Choice hybrids, best all

colors ................................ 20c Iarge Flowering Fringed-Mixed ........ Pkt., 15c Blotched and Striped ................... 15c Grandiflora-Best mixed. Large flower-

ing. Many colors and varieties......Pkt., 10c Pure white ........................... 5 c Fine Mixed-In great variety .........Pkt., 5c

\section{PHIOX DRUMMONDII}

The blooms of Phlox Drummondii are unrivaled for richness and beauty of color, ranging from white to the deepest scarlet and purple. They are abundant, almost covering the foliage, and of long duration. Very desirable, and easily grown. Hardy annual, one foot high; may be planted in the fall or early spring.

Alba-Pure white ............... 10k Black warrior-Dark purple .............. 10c Scarlet $\ldots \quad \ldots \ldots \ldots \ldots \ldots \ldots \ldots \ldots \ldots$ Pkt., 10c

Finest mixed-Including large, flowering

kinds

\section{PINK}

(Dianthus)

The dianthus family embraces some of the finest of all flowering plants. The blooms are of the richest and most pleasing colors, and nothing can surpass the exquisite fragrance of some varieties. They are hardy, and become perennial in warm climates and when protected. New seed should be sown every year or two. Old plants fail rapidly; young ones produce much the finest flowers, and the greatest number. One foot high.

Double China Mixed.

Double Diadem-Finest mixed. Ail col-

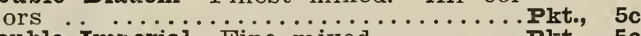

Double Imperial-Fine mixed .........Pkt., 5c

Double Japan-Beautiful fringed varie-

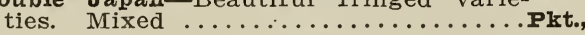

\section{POPPY}

(Papaver)

The poppy is well known and realiy a magnificent flower; borne separately, on tall stalks; both double and single, and of many bright colors. They are hardy annuals, and may be sown as soon as the ground can be prepared. By lancing the flower stalks of the Double Carnation variety, when in bloom, opium is obtained. Ten to twenty inches high.

The Shirley-A strain of marvelous beauty, with colors ranging from pure white to rose, pink, carmine, and brilliant crimson; some are edged with white. The petals have a glossy, silklike texture ....................... 5 P Double Scarlet-Carnation flowered................... 5c Double white-Carnation flowered........Pkt., 5c Double mixed-In great variety. Very choice ........................... 5c

\section{PORTUIACA}

The brightest of all flowers for bedding purposes. In bloom from early summer until killed by frosts. The single varieties are even more handsome than the double, and a paper of Grandiflora Single Mixed will produce a bed of unrivaled beauty. Thrives best in a sunny exposure and a light, sandy soil. Annual, of easy cultivation, ten to twelve inches high.

Single Mixed ..................... 5 c Double Irixed $\ldots \ldots \ldots \ldots \ldots \ldots \ldots \ldots \ldots \ldots$ Pkt., $10 \mathrm{c}$

\section{PRIMROSE, FVENING}

(Oenothera)

The Oenothera, or Evening Primrose, produces large, showy blossoms, which are fully expanded only during the evening and early in the morning. The flowers, which are from three to four inches across, attract much attention, on account of their size, beauty and rapidity with which they open. They are constant and prolific bloomers. The following are the best perennial varieties:-

Iamarkiana-Height four feet, with gor-

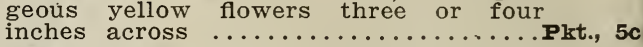

Aculis Alba-Dwarf, producing large, beautiful, pearl-white flowers. Hardy perennial, prostrate habit, six inches high . ...................... 5 c

\section{PRIMUIA SINENSIS}

(Chinese Primrose)

Well-known greenhouse and conservatory winter-blooming plants. Nothing can surpass them for pot and indoor blooming plants. Their various forms and blending of colors are exceedingly pleasing and effective. They thrive best in a sandy loam and leaf mold. Tender perennial.

Fimbriata - Choice fringed varieties mixed ........................ 25c Alba-Pure White ..................... 25c Fern-Ieaved Choice IMixed ................... 25c Extra Mixed-In great variety ................. 25c

\section{PYRETHRUM}

Useful bedding plants, and some of the new and improved varieties are among the best edging and border plants in cultivation. They produce handsome flowers, and the foliage of some varieties contrasts with charming effects with the amaranthus, centaureas, and other ornamental foliage plants. Hardy perennials, of easy cultivation.

Roseum-Dried flowers of this variety,

pulverized, form Persian insect pow-

der .......................... 10c Choice Mixed ..................... 10c

\section{RIODANTHE}

A dwarf everlasting flower, of great merit Succeeds best in a light, rich soil and a warm, sheltered situation. Cut as soon as fully blown, and dry in the shade. Half-hardy annual.

Extra Mixed-All colors ................. 5c

\section{SAIPIGIOSSIS}

Pretty, ornamental annuals, bearing richlycolored, funnel-shaped flowers. Marbled, yellow, crimson, scarlet, purple, and blue. A handsome, desirable plant of easy cultivation, deserving more general attention.

Finest Mixed .Pkt., 5c

\section{SAIVIA}

(Flowering Sage)

Very ornamental plants. Flowers borne ir spikes of fiery red, crimson, and blue, continuing in bloom until late in fall.

Salvia Splendens-Bright scarlet .......Pkt., 10C Salvia Patens-Pure blue...................... 10c Salvia mixed .............................. 10 


\section{DESCRIPTIVE LIST OF CHOICE FLOWERS - Continued}

\section{SCABIOSA}

(Mourning Bride)

Handsome flowers, of delicious fragrance, borne on long, branching stalks, that have but little foliage. The flowers resemble in appearance some varieties of dahlias, and are very symmetrical. Colors vary from white to purple and scarlet. Half-hardy perennial, of easy cultivation.

Finest Double Mixed Dwarf-All colors.. Pkt., 50 SCARIET FIAX-See Linum.

\section{SCHIZANTHUS}

Elegant, free-flowering, garden and greenhouse plant. Half-hardy annual and free bloomer, of branching habit. Very fine.

Fine Mixed Varieties-Of all colors......Plkt., 5c

\section{SENSITIVE PLANT}

(Mimosa)

A peculiar plant, with globular heads of pink flowers, interesting on account of the irritability of its leaves and stalks, which will, on being touched or shaken, close and droop as if dead. Tender Annual .................... 5 ckt.,

\section{SMILAX}

The most useful and beautiful of all climbins plants for florists. Its graceful form and elegant foliage are admired by all. It can be trained from pots or hanging baskets around windows and over ceilings, with charming effects. Useful for

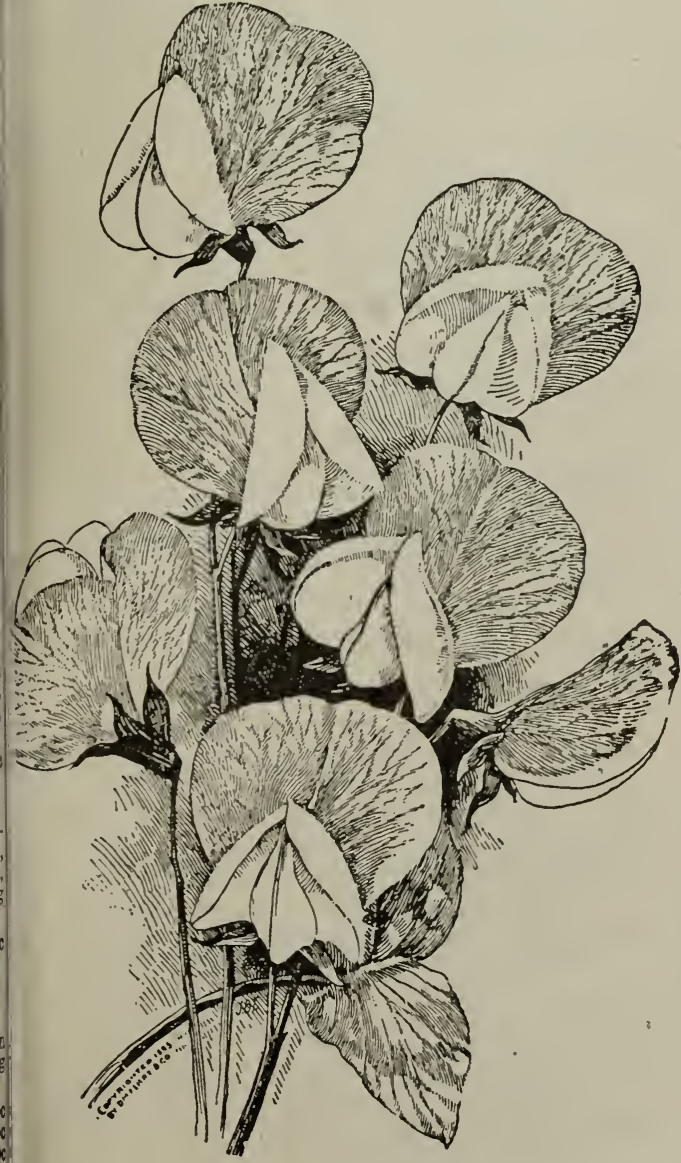

cut flowers and vases. It may be made to climb or droop, as desired. Tender perennial.

$$
\text { Pkt., } 5 \mathrm{c}
$$

\section{SNAPDRAGON}

(Antirrhinum)

One of the most useful and showy of border plants. Of almost every color, and striped as beautifully as carnations. They have recently been much improved, and are now really magnificent. The flowers are singular in form, and, when taken between the thumb and finger, and alternately pressed and released, will open and close with a snapping motion, from which they take their name. Hardy perennials of easy cultivation. Tall Varieties Mixed ................. 5 c Dwarf Varieties Mixed $\ldots \ldots \ldots \ldots \ldots \ldots$ Pkt., 50

\section{SOIANUM}

An interesting, ornamental greenhouse and garden shrub, having beautiful glossy leaves and handsome, scarlet fruit; very attractive and showy. Half-hardy perennial.

Capsicastrum-Jerusalem Cherry, or min-

iature orange tree. Covered with small

scarlet fruit ................... 100 Fine Mixed ........................

\section{STOCKS}

The stock, known by some as Gilliflower, has in recent years been so greatly improved as to be considered almost indispensable for bedding and edgings. Its varied and brilliant colors, profusion of blooms, and delicious fragrance render

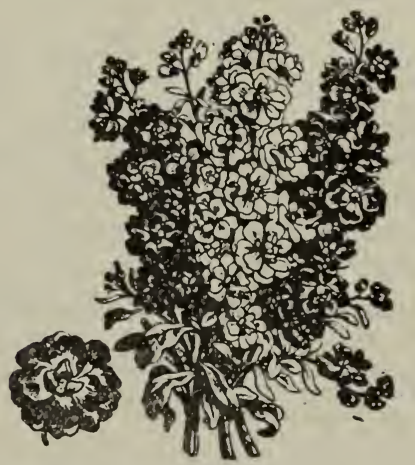

it a popular favorite. Some of the colossal varieties, which are included in the large flowering finest mixed, are truly magnificent. Hardy annuals, except where noted.

Double German Ten-Weeks-Mixed...... Pkt., 50

Double Ten-Weeks-Pure white......... Pkt., 100 Emperor or Perpetual-Beautiful colors.

Mixed perennial ..................... 15c

Brompton-Mixed, all colors........... Plkt., 15c

\section{SUNF工OWER}

(Helianthus)

A well-known plant, adapted, by its stately growth, for a bankground to the lawn or a screen to hide unsightly places. It is also known as an absorbent of miasma, in damp or ill-drained situations. The flowers, especialy of the double varieties, are really quite attractive.

Double Orange-Californicus .........Pkt., $5 c$ Globosus ristulosus-Large, deep yellow.

Very double ........................... 100 Mammoth Russian-Largest single vari-

ety. (See also Vegetable List.).....Pkt., $5 \mathrm{c}$

\section{SWEET PEAS}

our list is comprised of the seventy-flys best varieties.

The almost endless number of distinct varieties makes the sweet pea one of the most popular and 


\section{DESCRIPTIVE LIST OF CHOICE FLOWERS-Continued}

interesting flowers cultivated. It is one of the best climbing annuals; very free flowering, with an almost endless variety of shades and markings. The flowers are produced in great abundance for a long period.

CULTURE.-Plant the seed in rich, mellow soil, taking care not to cover it more than two inches. When the plants are about five inches high, furnish support for the vines to run upon. Cut the flowers freely, for, if the seed-pods are allowed to form, the plants will soon stop flowering.

We always add the new varieties to our List, if not listed here write us.

\section{WHITE}

Blanche Burpee-One of the best pure white varieties.

Pkt., 5c; 0z., 10c; 1/4, 1b., 20c; 1b., 50c

Emily Fenderson-The best white in cultivation; the flowers are of the largest size and pure white. A vigorous grower and free bloomer.

Pkt., 5c; oz., 10c; 1/4. 1b., 20c; 1b., 50c

Mrs. Sankey-Although this is classed as a pure white, in some lights it shows a tinge of warm shell pink which is very delicate and beautiful.

Plkt., 5c; 0z., 10c; 1/4, 1b., 20c; 1b., 50c

Queen of England-One of the best of the pure whites.

\section{Pkt., 5c; oz., 10c; 1/4 1b., 20c; 1b., 50c}

VFRY IIGHT PINK, AIMOST WHITE

Iemon Queen-Standards very light pink and light straw, blended and shaded on white.

Pkt., 5c; 0z., 10c; 1/4 ,1b., 20c; 1b., 50c

IModesty-White, tinted with pink.

Pkt., 5c; oz., 10c; 1/4. 1b., 20c; 1b., 50c

Ramona-Blush and white striped, of good sizs and form.

Pkt., 5c; oz., 10c; 1/4 1b., 20c; 1b., 50c

Sensation-Large flowers, light buff, blush, and white.

Pkt., 5c; 0z., 10c; 1/4, 1b., 20c; 1b., 50c

\section{IIGHT PINK AND PRIMROSF.}

Coquette-Standard, mauve and fawn, blended on primrose; wings, primrose.

Pkt., 5c; oz., 10c; 1/4, 1b., 20c; 1b., 50c

Iottie Hutchins-Primrose, striped with pink. Very beautiful.

Pkt., 5c; oz., 10c; 1/4 1b., 20c; 1b., 50c

Stella Morse-Buff, with tint of pink, showing a litle deeper at the edges; standard and wings the same.

Plkt., 5c; oz., 10c; 1/4, 1b., 20c; 1b., 50c

\section{PAIE YEIIOW OR PRIMIROSE.}

Mrs. Fcford-White, shaded with primrose; delicate and rich.

Pkt., 5c; oz., 10c; 1/4. 1b., 20c; 1b., 50c

Queen Victoria-Light primrose yellow; hardy and of good substance.

Pkt., 5c; oz., 10c; 1/4. 1b., 20c; 1b., 50c

\section{SHADFS OF PINK.}

Blushing Beauty-Light pink, with a suggestion of mauve.

Pkt., 5c; oz., 10c; 1/4. 1b., 20c; 1b., 50c

Katherine Tracy-Soft, brilliant pink in color a free bloomer; very vigorous and hardy.

Pkt., 5c; oz., 10c; 1/4. 1b., 20c; 1b., 50c

Mrs. Gladstone-Large, beautiful flowers; standards, delicate soft pink.

Pkt., 5c; 0z., 10c; 1/4. 1b., 20c; 1b., 50c

Prima Donna-Very large, perfect flowers, of a brilliant yet soft shade of pink.

Pkt., 5c; oz., 10c; 1/4 1b., 20c; 1b., 50c

Princess Beatrice-Standard, light pink, shaded with buff. Wings, bright rose pink.

Plt., 5c; Oz., 10c; 1/4, 1b., 20c; 1b., 50c
Royal Robe-Bright, rose-pink flowers; very lar hooded form.

Pkt., 5c; oz., 10c; 1/4. 1b., 20c; 1b., 50c

Venus-A soft, salmon-buff self-color; of lar size and hooded form. While a vigorous gro er, it is graceful, delicate, and decidedly attra tive.

Pltt., 5c; oz., 10c; 1/4. 1b., 20c; 1b., 50c

\section{ROSE AND PINK}

Apple Blossom-Standard crimson pink. Win white, tinged and shaded with pink.

Pkt., 5c; 0z., 10c; 1/4. 1b., 20c; 1b., 50c

Blanche Ferry, Extra Early-The earliest swe pea in cultivation; the large pink and whi flowers and very showy; the plant is vigoro and an exceedingly free bloomer.

Pkt., 5c; oz., 10c; 1/4. 1b., 20c; 1b., 50c

Crown Jewel-Violet rose and primrose. A ve beautiful sort.

Plkt., 5c; Oz., 10c; 1/4 1b., 20c; 1b., 50c

Fliza Eckford-Large flower. Rosy pink white ground. Exceedingly delicate.

Pkt., 5c; oz., 10c; 1/4 1b., 20c; 1b., 50c

Isa Eckford-Delicate creamy-white and pink flowers; of beautiful form.

Pkt., 5c; 0z., 10c; 1/4. 1b., 20c; 1b., 50c

Iovely-Large, beautiful flowers. A delica shade of pink.

Pkt., 5c; oz., 10c; 1/4 1b., 20c; 1b., 50c

Royal Rose-Standard, deep rose pink; win a lighter shade of the same color. One of $t$ largest and best of the pink sorts.

Pkt., 5c; Oz., 10c; 1/4. 1b., 20c; 1b., 50c

\section{ORANGE AND PINK}

Aurora-Striped and flaked with delicate, orang salmon pink over white ground. Very brillia and beautiful.

Pkt., 5c; oz., 10c; 1/4 1b., 20c; 1b., 50c

Iady Mary Curry-Crimson orange pink, distinct and beautiful.

Pkt., 5c; 0z., 10c; 1/4 1b., 20c; 1b., 50c

Iady Penzance-Orange pink, showing veins orange rose.

Plkt., 5c; oz., 10c; 1/4 1b., 20c; 1b., 50c

Mrs. Joseph Chamberlain-White, striped wi bright rose carmine. Very distinct and stri ing.

Pkt., 5c; Oz., 10c; 1/4. 1b., 20c; 1b., 50c

Orange Prince-Standards, pink, suffused wi orange; wings, bright lake pink. Very d tinct in color.

Pkt., 5c; oz., 10c; 1/4. 1b., 20c; 1b., 50c

Oriental-Deep orange pink, of good substan very large, and finely formed.

Pkt., 5c; oz., 10c; 1/4. 1b., 20c; 1b., 50c

\section{IAVENDER AND MAUVE}

Butterfly-White, tinted with lilac; very delica and beautiful.

Pkt., 5c; oz., 10c; 1/4, 1b., 20c; 1b., 50c

Captain Clark-Standard, white, shaded light with crimson. Wings, white, shaded with la ender.

Pkt., 5c; 0z., 10c; 1/4 1b., 20c; 1b., 50c

Captivation-Standard, magenta. Wings, san with a suggestion of purple; almost self-color This is a distinct shade in sweet peas.

Pkt., 5c; oz., 10c; 1/4, 1b., 20c; 1b., 50c

Countess of Radnor-Self-colored in a very d: tinct and beautiful shade of lavender.

Pkt., 5c; Oz., 10c; 1/4 1b., 20c; 1b., 50c

Dorothy Tennant-Rose purple, self-color Large size, very distinct and beautiful.

Pkt., 5c; oz., 10c; 1/4. 1b., 20c; 1b., 50c

Emily Eckford-Rose purple, suffused with bli

Pkt., 5c; 0z., 10c; 1/4. 1b., 20c; 1b., 50c

Gray Friar-Heliotrope, marbled on white. Lar size, hooded form.

Pkt., 5c; Oz., 10c; 1/4 1b., 20c; 1b., 50c 


\section{DESCRIPTIVE LIST OF CHOICE FLOWERS - Continued}

uanita-Large, beautiful flowers. Pure white, striped with a delicate shade of lavender.

Pkt., 5c; oz., 10c; 1/4 lb., 20c; 1b., 50c

ady Nina Balfour-Standard mauve, wings lavender. Large and finely formed.

Pkt., 5c; oz., 10c; 1/4. 1b., 20c; 1b., 50c

ottie Ickford-Standard, a delicate shade of magenta blue; wings, shaded lavender, deepening into violet at edge.

Pkt., 5c; 0z., 10c; $1 / 4$ lb., 20c; 1b., 50c Iaid of Honor-Standard, white, shaded with lilac. Wings, white, shaded with lavender.

Pkt., 5c; oz., 10c; $1 / 4$ lb., 20c; 1b., 50c

\section{BRIGHT RED}

merica-White, nearly covered with splashes, stripes, and dots of bright carmine. Very brilliant.

Pkt., 5c; 0z., 10c; 1/4 1b., 20c; 1b., 50c ardinal-Deep, rich, carmine-red flowers of robust habit, and one of the brightest reds in cultivation.

Plst., 5c; oz., 10c; 1/4. 1b., 20c; 1b., 50c 'irefly-An intense crimson scarlet, of large, open, and expanded form. One of the best bright reds yet offered, and its fiery coloring makes it a most desirable boquet variety.

Pkt., 5c; oz., 10c; 1/4, 1b., 20c; 1b., 50c

gnea-Bright red. Practically self-colored, though wings are more crimson in well-matured blossoms.

Pkt., 5c; oz., 10c; 1/4. 1b., 20c; 1b., 50c Iars-Bright red, self-colored. Rather above medium size. Hooded form

Pkt., 5c; oz., 10c; 1/4, 1b., 20c; 1b., 50c alopian-Flowers are of grand size and wellexpanded form. Standards quite broad, of good substance, slightly pointed, with the upper edges well recurved. Coloring is a vivid red. The wings are large, slightly recurved, deep red, tinged with rose.

Plst., 5c; 0z., 10c; 1/4 1b., 20c; 1b., 50c unproof-Color intense fiery red; one of the richest-colored sorts yet introduced. The flowers are faultless in form and of exceptionally good substance.

Pkt., 5c; 0z., 10c; 1/4. 1b., 20c; 1b., 50c

\section{SCARIET AND CRIMSON}

ashion-Rose-magenta, self-colored. A distinct shade.

Plkt., 5c; oz., 10c; 1/4. 1b., 20c; 1b., 50c

laiety-Light magenta rose striped on white. The color turns pure magenta with age.

Plkt., 5c; 0z., 10c; $1 / 4$ 1b., 20c; 1b., 50c

Ier Majesty-Bright rose crimson. Large size, hooded form. Very vigorous.

Pkt., 5c; oz., 10c; 1/4. 1b., 20c; 1b., 50c Iiss Hunt-Standard, scarlet crimson. Wings, chimson. Pink showing views of deeper crimson.

Plkt., 5c; oz., 10c; $1 / 4$ lb., 20c; 1b., 50c rince Edward of York-Bright scarlet and crimson.

Pkt., 5c; oz., 10c; 1/4 1b., 20c; 1b., 50c

!ueen of the Isles-White ground, distinctly striped and splashed with carmine and bright scarlet.

Pkt., 5c; oz., 10c; 1/4 lb., 20c; 1b., 50c ied and White striped-Large flowers of good substance.

Pkt., 5c; oz., 10c; 1/4 1b., 20c; 1b., 50c plendor-A large, finely-shaped flower; color coppery crimson suffused with rose.

Plat., 5c; oz., 10c; $1 / 4$ 1b., 20c; 1b., 50c

BIUE AND PURPIE

lack-Standards, deep maroon; wings deep blue, medium size; good substance, black seed. Pkt., 5c; oz., 10c; $1 / 4$ 1b., 20c; 1b., $50 \mathrm{c}$ tton-Dark maroon, self-colored.

Pkt., 5c; oz., 10c; $1 / 4$ 1b., 20c; 1b., 50c
Captain of the Blues-One of the largest of the blue; wings a little lighter shade of blue.

Pkt., 5c; oz., 10c; 1/4 1b., 20c; 1b., 50c

Duke of Clarence-Very deep rosy claret. One of the largest flowering varieties, and the very best of the dark colors.

Pkt., 5c; oz., 10c; 1/4. 1b., 20c; 1b., 50c

Indigo King-A large, fine-shaped flower, and one of the darkest, deep maroon standards and indigo-blue wings.

Plt., 5c; oz., 10c; 1/4. 1b., 20c; 1b., 50c

Monarch-Standard dark violet and purple, wings violet. A very dark variety.

Pkt., 5c; oz., 10c; $1 / 4$. 1b., 20c; 1b., $50 \mathrm{c}$

Navy Blue-Very large and of fine form. An exceedingly rich deep blue.

Pkt., 5c; oz., 10c; 1/4. 1b., 20c; 1b., 50c

Princess of wales-Standard purple, wings blue, both striped on white.

Plkt., 5c; 0z., 10c; 1/4. 1b., 20c; 1b., 50c

Senator-Standard maroon and violet, wings violet and indigo, both striped on white.

Pkt., 5c; oz., 10c; 1/4. 1b., 20c; 1b., 50c

Shahzada-Beautiful rich flowers. Standards, deep maroon; wings, indigo blue.

Pkt., 5c; oz., 10c; 1/4. 1b., 20c; 1b., 50c

Stanley-A beautiful, self-colored flower of deep maroon.

Pkt., 5c; oz., 10c; 1/4. 1b., 20c; 1b., 50c

waverly-Pure purple.

Plkt., 5c; oz., 10c; 1/4. 1b., 20c; 1b., 50c

Eckford's Hybrids Mixed-This mixture is made up of Eckford's large flowering sorts.

Plat., 5c; oz., 10c; $1 / 4$ 1b., 15c; 1b., $40 \mathrm{c}$

Choice Mixed-A fine mixture of the best varieties, new and old.

Pkt., 5c; oz., 10c; 1/4 1b., 15c; 1b., $40 c$

Mammoth Package Mixed Sweet Peas-Many of the new sorts are in this mixture. The colors are rightly proportioned to give the most brilliant show possible in the garden. Pkt., $10 \mathrm{c}$

SPECIAI NOTICE-One package each of our 75 named varieties of sweet peas, amounting to $\$ 3.75$, mailed to any address, post-paid, on receipt of .............\$2 50

Any 50 varieties, amounting to $\$ 2.50$, postpaid, to any address.................. 175

\section{Dwarf Sweet Peas}

Pink Cupid-Plants very dwarf, and much more vigorous than White Cupid. The flowers are of the same color as those of Blanche Ferry, and somewhat larger.

Pkt., 5c; oz., 10c

White Cupid-A genuine dwarf; plant only a few inches high; bloom of good form and substance, and pure white. Originated in California. Seeds white.

Plkt., 5c; oz., 10c

\section{SWEFT WIIIIAM}

(Dianthus Barbatus)

A well-known, remarkably free-flowering plant, of brilliant colors, ranging from snow white to darkest crimson and purple. They emit a very delicate and refreshing fragrance. New plants should be raised from seed every year or two, as the old ones deteriorate. They are hardy, and the seed may be sown as soon as the ground can be prepared. They spread rapidly, and the roots can be divided. Hardy perennial.

Single Mixed-Very beautiful ..........Pkt., 5c Double Irized .................. Pkt., $10 \mathrm{c}$

\section{VERBENA}

No plant surpasses the verbena as a bedding plant under our bright California sun. The colors are rich and distinct. A packet of our new hybrid seed will produce flowers of every shade and color known to the verbena. They spread 


\section{DESCRIPTIVE LIST OF CHOICE FLOWERS--Continued}

rapidly and can be divided. and will set readily. Half-hardy perennial trailer.

White Niveni-Sweet scented..........Pkt. 5c Scarlet Defiance-Very brilliant......... Pkt., 10c Montana-Hardy variety, producing bril-

liant rose and lilac flowers............ Pkt., $5 c$ Fine Mixed-Brilliant colors ..........Pkt., 5c Hybrida-Saved from one of the finest

collections in the world.............. 15c

\section{WAII FIOWIR}

(Cheiranthus Cheri)

A well-known, half-hardy perennial, producing spikes of beautiful flowers. The petals are velvety, the color deep orange, shading to brown, rich and handsome. If taken in or protected, they will bloom all winter.

Finest Double Mixed.............Pht., 10c

\section{WHITIA VIA}

An attractive, hardy annual, with beautiful. fine foliage. bearing profusely drooping clusters of bell-shaped flowers. mostly blue and white. Should have a shady place with abundant moisture.

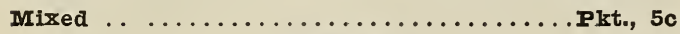

\section{WISTARIA}

\section{(Glycine Sinensis)}

Rapid-growing, hardy, perennial climber, bearing long, drooping clusters of porcelain-blue flowers in abundance. Thrives best in a light, loose soil and a southern exposure. Often grows fifteen feet in a season.

\section{Pkt., 20c}

\section{XERANTHEIMUIM.}

A free-flowering class of everlastings; useful for winter bouquets. The colors are purple, yellow and white. They should be gathered before they are fully opened, and dried in the shade. Thus treated and carefully kept, they will retain their beauty for years. Hardy annuals.

Double Mixed-Choice colors ........... 10kt., 10c

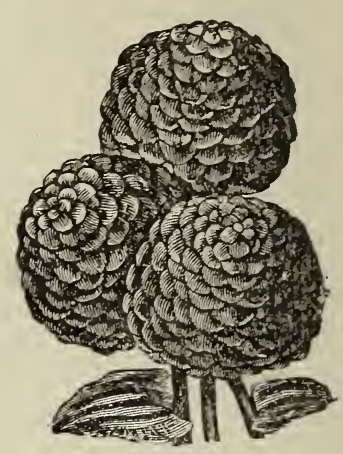

ZINNIA

A large-flowering, branching annual, in bloom the latter part of the season. The flowers are as double as dahlias, which they resemble, and of almost as great a variety of rich colors and shades. The flowers are beautifully rounded on top and very symmetrical. They can be dried and will remain fresh in appearance and handsome for winter bouquets. Easily grown and transplanted, and remarkably showy for beds or as a low hedge. Half-hardy annuals.

Double white ................. 5 ckt.,

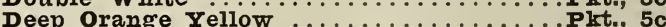
Extra Double Mized $\ldots \ldots \ldots \ldots \ldots \ldots \ldots \ldots$ Pkt., $5 c$

\section{Roses}

All our Roses are grown on their own roots and are far superior to budded plants.

Culture-Remove all decayed branches and leaves and at least half the previous season's growth should be cut away early each spring. Spade around the roots plenty of well-rotted manure and give surface a liberal top dressing of bone dust.

Liberty (H. S.)

Red.

Papa Gontier (H. T.)

Gen. Jacqueminot (H. P.)

Meteor (C).

Reine Marie Henriette (C)

Prince Camille de Rohn

(H. P.)

Gen. MacArthur (H. T.)

Gruss-au-Teplitz (H. T.)

Jubilee (H. P.)

Wooten (C.)

Philadelphia Rambler (C.)

Helen Gould (H. T.)

Urich Brumer (H. P.)

Richmond (H. T.)

Crimson Rambler (C.)

Bridesmaid (T.)

Killarney (H. T.)

Cecil Brunner (H. T.)

Malmaison (C.)

Mad. Caroline Testout (H. T. )

Paul Neron (H. P.)

Burbank (H. T.)

La France (H. T.)
Clio (H. P.)

Glorie de Dijon (C)

Magna Charta (H. P.)

Catherine Mermett (T.)

Maman Cochet (H. T.)

La France (C.)

Hermosa (T.)

Mrs. Mawley (T.)

Bride (T.)

white.

Kaiserin Aug. Victoria

(C.)

Cherokee (C.)

Lamarque (C.)

Kaiserin Aug. Victoria (H. T.)

Bessie Brown (H. T.)

Gold of Opper (C.)

Marachal Neil (C.)

Maman Cochet (H. T.)

Croquette de Lyon (T.)

Sunset ( T.)

Etoile de Lyon (T.)

Wm. Allen Richardson

(C.)

F. P.-Hybrid Perpetual-These are the hardiest of all roses; many will stand the coldest sections; vigorous in growth and easy of culture, producing large flowers, fine in form and fragrance.

T.-Tea-One of the best classes of roses and truly ever-blooming. Many of these are the most beautiful and sweetly scented; they are hardy in this section, frequently wintering without any protection, although during the coldest weather they should be protected with a covering of fir boughs, straw or burlap. 
ROSES-Continued

H. T.-Hybrid Tea-These, as a rule, are as free-flowering and as constant bloomers as the tea sorts. They are hardier than the teas, but, as a rule, not so hardy as the H. P.'s. Many of this class, however, are practically hardy and a few very hardy.

C.-Climbers.
PRICES.

Choice, two-year-old stock, $35 \mathrm{c}$ each, 6 for $\$ 1.75$; 12 for $\$ 3.00$.

Selected, three-year-old stock, 50c each; 6 for $\$ 2.50$; 12 for $\$ 4.00$.

One-year-old, malling ize, 15c each, $\$ 1.25$ per dozen, postpald, from April 1, 1907.

Parties who expect to bur roses by the hundred will do well to write us for Special Prices.

\section{NITRO-CULTURE}

\section{NEW DISCOVERY}

A new, sure and easy way has recently been discovered to make worn-out or poor land enormously productive with a little trouble and almost without expense. Plants need nitrogen and cannot grow without it. Heretofore fertilizers have been needed to put nitrogen into the soil. Nitrogen is very necessary-is the most expensive part of fertilizers. The new way is easier, surer, cheaper-it is to let nitrogen-gathering germs feed the plants.

The soil is full of air. Air is four-fifths free nitrogen. Think what limitless plant food, in the form of free nitrogen. the air contains. Right here the new discovery comes in. Plants cannot extract nitrogen from the air, but there are germs that can. These germs have been discovered and are now being used for that purpose. These germs, when put into the soil, fasten themselves to the roots of the plants, draw the free nitrogen out of the air, and feed it to the plants. That's the secret of the new way that is making many farmers rich. The germs do the work-the farmer gets the profit. They save expense, reduce the work, increase the crop enormously, even make it possible to grow Alfalfa and other crops where they never would grow before.

\section{DOUBLES YOUR CROPS}

The new way saves the cost of nitrogenous fertilizers and is very easy to use. The germs come ready for use, in a form called Nitro-Culture, put up in small dry packages you can put in your vest pocket. Simply add it to water, and sprinkle the water over the seeds before planting. The germs remain on every seed-live with it-increase about it-feed the roots when they start and keep on feeding them. They also enrich the soil by storing nitrogen in it, so that the second year's crop, whatever it may be, is increased from two to ten times.

NITRO-CUITURE is especially prepared for the following crops: Alfalfa or tucerne, Red Clover, Alsike Clover, White Clover, Field Peas, Garden Peas, Sweet Peas, Garden Beans, Vetch.

Then ordering state what particular kind of crop you desire to inoculate, so that the proper bacteria may be forwarded.

\section{Price Iist:}

Trial package, $1 / 8$ to $1 / 4$ acre, 50c; acre package, $\$ 1.50 ; 5$-acre package, $\$ 5.00$

Tie can also furnish $25 \mathrm{c}$ packages for Garden Peas and Beans and Sweet Peas.

Complete directions with each package. 


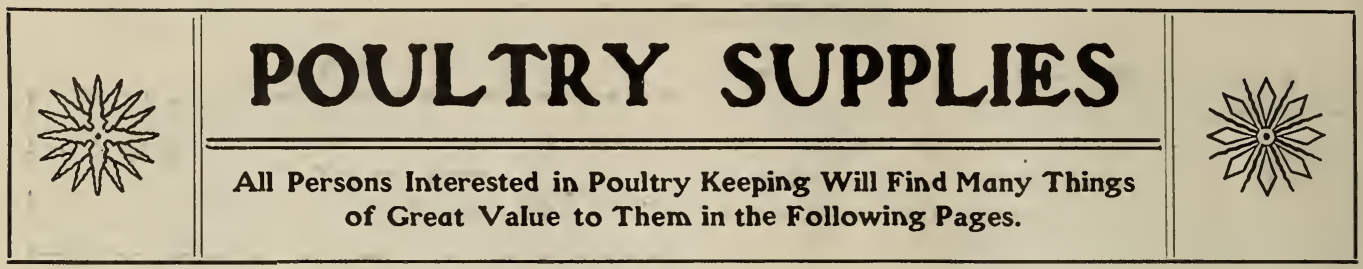

If it were not the fact it would seem incredible that even now the increasing populations of the Pacific Coast are largely dependent upon the Midand eggs, but such is the cold, hard fact. With all our advantages of climate, it is an absurdity, and an anomalous reflection upon Pacific Coast enterprise, that we should in this twentieth century be paying freight charges on eggs and poultry raised for our tables in the severe climates beyond the Rockies. But the people of the Pacific Coast are at least awakening to the importance of the pouitry industry. This means a demand for incubators, the old hen process being too slow to meet the demands of the general eagerness to make up for lost time. Of the makes of incuba-
tors there is no end and to choose the best from among them all is a point of the utmost importance. Before deciding in favor of any one kind of incubator we examined the merits of many competing machines with the utmost care. The result was a decision in favor of the Cyphers as the most scientifically designed, the most carefully constructed, and in all respects the best and simplest incubator on the market. Having made this decision, our shipment of four carloads of Cyphers incubators and brooders five years ago was only a starter in this branch of business. We disposed of the original shipment long ago, and several successive shipments have followed since. Now that the Pacific Coast prices of the Cyphers incubators and brooders are practically reduced to the level of the Eastern factory prices, the demand for these goods must be greater than ever.

\section{THE CYPHERS NON-MOISTURE INCUBATORS}

The Cyphers incubators, for which we are by the manufacturers. as follows:-

First-To require no supplied moisture.

Second-To be self-ventilating.

Third-To be self-regulating.

Fourth-To operate with less oil and at less expense than any other make of incubator. Fifth-To be fire-proof. having the best. the
safest, and the most costly built heater attarined to any incubator.

Sixth-To be the easiest to operate and control, requiring less labor and attention than any otlier make of incubator.

Seventh-To produce larger and stronger chicks than any other make of incubator on the rilarket. Eighth-Also that, where they are run with any incubator of a different make, they will in three or more hatches bring out a larger percentage of the fertile eggs in good, healthy chicks or ducklines than does their competitor.

If you are in search of the latest-patented, most durably-built, and best practical incubator, one that will hatch the largest number of the strongest and healthiest chicks or ducklings. the Cyphers is that machine.

Who invented them?-The now famous Cyphers incubators, which were patented in 1894, first placed on the market during the season of 1896-97, and now extensively used on the largest poultry plants in America, were invented by Charles $A$. Cyphers, also inventor of the Mammoth 20,000Egg Cyphers Incubators located on the duck farm of Wm. H. Truslow, at Stroudsburg, Pa. Mr. Cythe study of artificial incubating and brooding, "Incubation and Its Natural Laws" (conceded to be the best scientific and practical treatise given to the public on this subject to date), the construction of the mammoth 20,000-egg Cyphers incubator at Stroudsburg, and the inrention of the 60-egg, 120-egg, and 360-egg C'ypher's iz:cubators and the 3-compartment Cyphers brooders.

THE "DIFFUSIVE PRINCIPLE”-Mr. Cyphers is the discoverer and patentee of the "diffusive principle" in artificial incubation, a highly important matter, for it was by means of this discovery that he was enabled to render his greatest service to practical, successful incubation by artificial means, by solving "the moisture pioblem." Tintold thousands of chicks were being reported "dead in the shell," and the moisture question was the rock on which the hopes of hundreds, yes. thousands, of poultry raisers were being wrecked. The Cyphers method and the Cyphers incubators
SOLVED THIS PROBLEM by introducing the diffffusive principle and a self-ventilating system, which does away absolutely with supplied moisture, retaining in the machine the moisture contained in the eggs, which is ample for all purposes.

THE RESULT IS AN INCUBATOR THAT IS POSITIVELY SELF-REGULATING, SELF-VENPLIED MOISTURE. Here we have, therefore, the simplest possible incubator, one that is practically perfect in its ease of operation, as all that is required of the attendant is the filling of the lamp and turning the eggs. Today the Cyphers incubator, a practical embodiment of the CYPHERS METHOD, stands without an equal. Used by the largest and most successful poultry plants in this country, and by upwards of 15,000 small poultry raisers, it is pronounced by them to be WITHOUT A RIVAL.

NON-MOISTURE INCUBATORS-The Cyphers is the original and only genuine non-moisture incubator. All other so-called "non-moisture" machines are either imitations or, worse still, merely claim to require no supplied moisture, in order that those who manufacture them may reap some of the benefits arising from Mr. Cyphers' great discovery and invention. The Cyphers incubators are today the only machines that are or can be lawfully equipped with the Cyphers patent felt diaphragms, thus employing the diffusive system of ventilation, which does away entirely with supplied moisture.

Several manufacturers of incubators have been forced to adopt various substitutes for $\mathrm{Mr}$. Cyphers' invention, while still others have not altered their old-style machines in any material point, but now boldly claim that they require no moisture pans, wet sponges, or supplied moisture in any form, thus defrauding the public, in order to sell their old-style, out-of-date incubators to persons not well informed. FOR POSITIVE and ABUNDANT PROOF that the Cyphers is the original and only genuine non-moisture incubator, and that, by solving "the moisture problem," $\mathrm{Mr}$. Cyphers did artificial incubation and the poultry industry of America, a very great service, read the hundreds of testimonials in Cyphers Company's Complete Catalogue for 1907.

BUILT FOR BUSINESS. The Cyphers incubators and brooders are built for business. That is the idea. There is nothing fancy, nothing foolish, about them. They are not parlor ornaments. That is not what incubators are wanted for. Men and women of experience in the poultry business understand that it is at best a particular matter to hatch and raise large numbers of strong, 


\section{POULTRY SUPPLIES--Continued}

healthy chicks by artificial means. Mr. Cyphers and the Cyphers Incubator Company fully realize this, and therefore they turn out the best goods they know how to produce, at the same time not wasting a cent on fancy trimmings, but striving to manufacture incubators and brooders that are exactly adapted to the work. Every Cyphers incubator or brooder is built in a workmanlike manner, out of the best materials on the market. and is sightly in appearance. While there is nothing fancy about them, no critic can place his hand anywhere on a Cyphers incubator or brooder and truthfully say. "This is inadequate; this is too cheap." In other words, every cent is spent on the Cyphers goods THAT IS NECESSARY, but nct a penny more. The result is that the Cyphers, capacity, quality of material, and Workmanship considered. are sold at reasonable prices, and the purchaser gets full value, GETS WHAT HE WANTS, - a practical incubator, and one that will last a lifetime with reasonable care.
ONE STYLE ONLY-The Cyphers incubators and brooders are manufactured in one style only, viz., THE BEST. The Cyphers Company, has no "second best." The best incubator that can be made is what the sensible poultryman wants, and nothing less than this. An extra $\$ 5.00$ or $\$ 10.00$ put into the "best incubator" will earn itself the first hatch, and the difference in every hatch thereafter will be clear profit, as between a poor incubator and the best that an up-to-date company can manufacture. Purchasers of incubators should reflect on these facts, and be governed accordingly. The poultry business is not boy's play. For earnest people it is the means to a livelihood. There is money in poultry for sensible people, for men and women who are governed by reason. For those who unfortunately follow cheap prices there is little hope in the poultry business. Cheap prices invariably mean cheap goods.
The Standard CYPHERS Incubators, 1907 Pattern

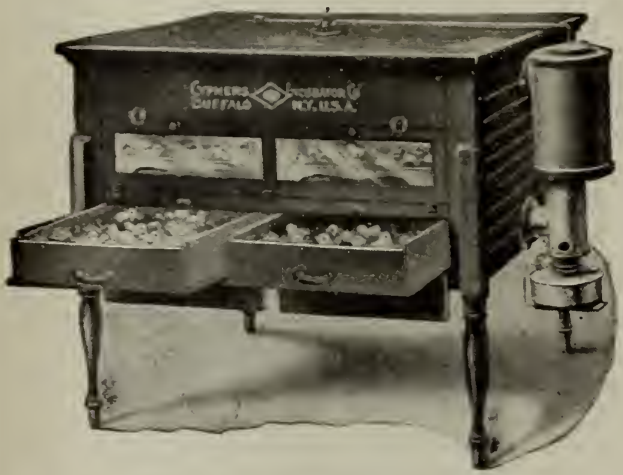

1907 Pattern Standard Cyphers.

\section{Cyphers New Low-Priced Incubators}

These incubators are well built and practical machines and will under ordinarily favorable conditions hatch a good percentage of eggs entrusted to them.

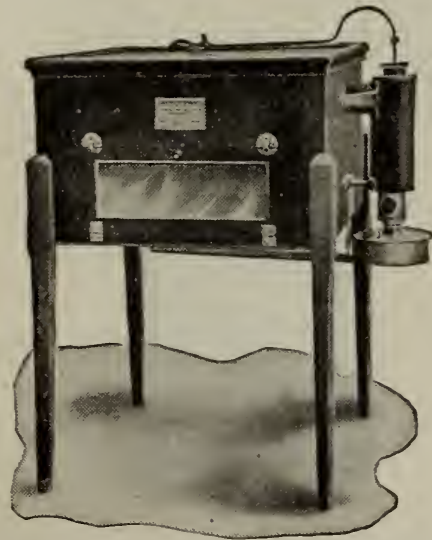

Farm Economy. Capacity. 110 eggs. Price.. \$13.50 Boy's Choice. Capacity, 50 eggs. Price....\$8.50
The Standard CYPHERS Incubators, 1907 Pattern, embody several new and important improvements which. while they do not in any way affect the working principle of the machine, add greatly to the ease of operation and to its durability.

We sell the genuine Cypher's Incubators at the following prices:

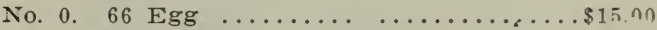

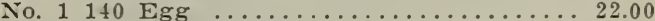

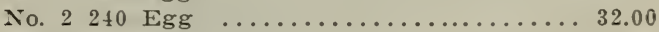

No. $3390 \mathrm{Egg} \mathrm{................} 38.00$

These machines are sold under a positive guarantee.

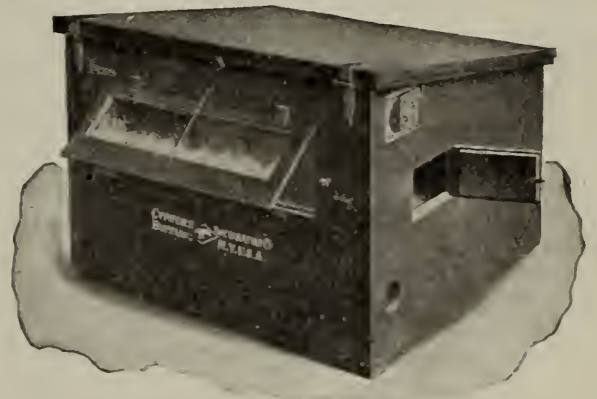

\section{Storm King Brooder}

Recognizing the widespread demand for a thoroughly well-made, practical brooder that can be sold at a lower price than our Standard "A" Brooder, we have devised and perfected the Storm King Brooder. This is a combined brooder and colony coop, manufactured in one size; has a floor space $34 \times 34$ inches, and is 75 -chick capacity. The heating principle employed in the Storm King is the sams as in the Style "A" Brooder,but adapted to meet the special requirements of this style of brooder. The entire floor space of this brooder, together with the lamp slide and other working parts, may be removed and roosts inserted, thus making a well-lighted, well-ventilated colony roosting coop.

Prices, complete, with thermometer and lamp

........................ $\$ 10.50$ 


\section{POULTRY SUPPLIES-Continued}

\section{Cyphers Hygeinic Brooder}

We offer this brooder with the opinion that it is the best device in the form of an individual indoor brooder thus far conceived and invented for the safe and healthful rearing of chicks. It is composed of three compartments, allowing the chicks to seek whatever temperature suits them best. The improved heating system is similar to that employed in the Storm King Brooders; the very best for the purpose.

Price. complete with thermometer and lamp $\$ 9.50$

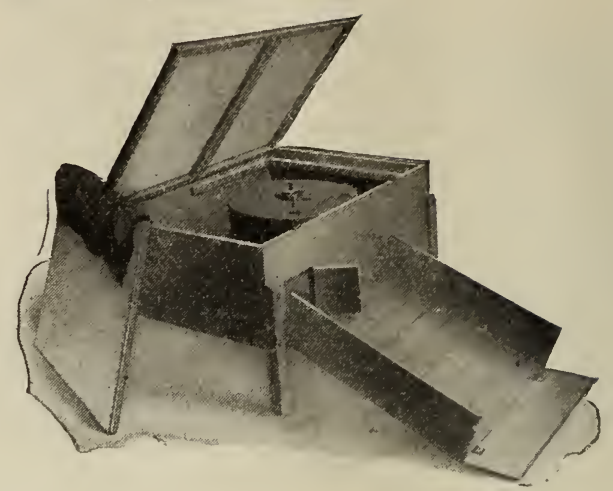

Cyphers Style A Three Compartment Brooder

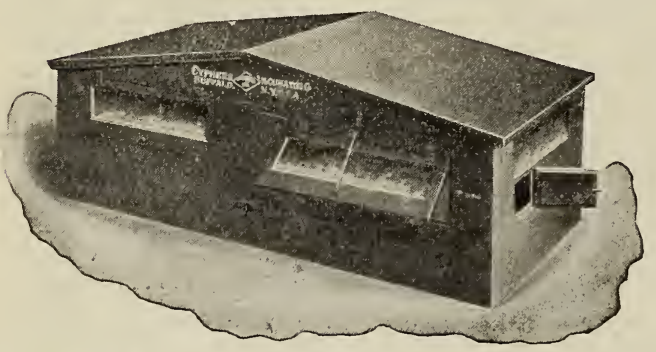

Cyphers Style A, Outdoor Brooder, Rear View

Next to its incubator, the Cyphers Company especially prides itself on the three-compartment outdoor brooder which it manufactures. We unhesitatingly pronounce this to be the best brooding device on the market, for EITHER INDOOR OR OUTDOOR USE, regardless of price, and it will be noted that all of the Cyphers brooders (the company manufactures one grade only, but four sizes), are sold at very reasonable figures.

LET US ENUMERATE SEPARATELY THE SPECIAL MERITS OF THIS BROODER.

First-It is the largest single-flock brooder ever placed on the market.

Second-It is rain-proof and storm-proof, having a heavy, canvas-covered rcof over both the chick chamber and the feeding compartment or run.

Third-It is fire-proof, a Cyphers safety brooder stove being used instead of a lamp, and the entire lower floor of the chick chamber being protected underneath by a solid sheet of galvanized iron, with an air space between it and the wooden floor.

Fourth-A brass cold-water pan is used on the Cyphers safety brooder stove, located betweell the flame and the oil bowl. Cold water placed in this pan keeps the wick from charring and the flame from smoking, thus rendering the stove and brooder perfectly safe, also insuring a uniform heat.

Fifth-The fumes from the brooder stove can not pass into the chick chamber (into either apartment), but are carried out at the sides of the brooder by an ingenious and infallible device.

Sixth-The surplus brooder stove heat preserves all the lower woodwork of the brooder by warming and drying the soil underneath the brooder. thus making the brooder not only safer and more comfortable for the chicks, but also more lasting.

Seventh-The brooder stove is easy of access, being aboveground, and the sliding board not only brings it quickly within reach, but replaces it in exactly the right location.
Eighth-When the temperature underneath the chick cover is at 90 to 95 degrees, we have a surrounding atmosphere of 80 to 85 degrees, while in the front compartment the temperature will average about 70 degrees. The chicks, therefore, may suit themselves, going to and from the heat at will. (See illustration.)

Ninth-The round chick guard prevents any crowding of the chicks, and also prevents their coming in contact with the circular heat dome, to their injury.

Tenth-In the night compartment of this brooder there are no stairs to climb, hence no danger of the little chicks getting lost and becoming chilled while learning the way.

Eleventh-It is the most durable and the bestmade brooder on the market, regardless of price. Both the chick chamber and front run may be reached through full-sized doors, and these doors or lids are covered with heavy tin, painted with two coats of mineral paint. We unhesitatingly recommend this brooder, both for outdoor and indoor use. It may be left out in rain-storms or wind-storms, and, with reasonable care, the chicks entrusted to it will be comfortable and do well. All chicks raised in brooders should be provided with outdoor runs, and be given necessary exercise, depending on the season and the weather. Many customers of the Cyphers Company have bought these unequaled outdoor brooders for use inside of poultry houses, brooder houses, etc., during midwinter, placing them out-of-doors, under trees or in the open, as socn as the early spring days came with their bright sunshine.

This is positively the best combined outdoor and indoor brooder in all particulars that the Cyphers Company knows how to build.

Capacity, 100 to 150 chicks; weight, 160 pounds. Price complete ................\$15.50
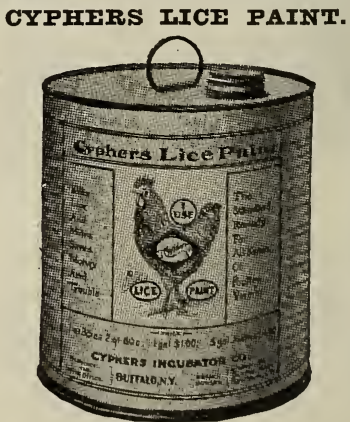

Quart cans, each...............\$ 0.35

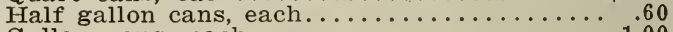

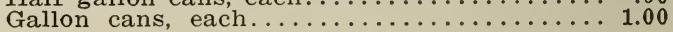




\section{POULTRY SUPPLIES-Continued}

\section{Cyphers Chick Food, Laying Food, Etc.}

Having made arrangements with Cyphers Incubator Co., we will handle nothing but their well known Poultry Food, which we buy by the carload and which we can offer at Coast prices. Send for samples of their Celebrated Chick Feed.

Cyphers Chick Feed, per 1b., 5 cents; in 100-1b. sealed bags, per 100 lbs...........\$3.50

Cyphers Forcing Food, per 1b., 3 cents; in $100-1 b$. sealed bags, per $100 \mathrm{lbs} . \ldots \ldots \ldots .2 .50$

Cyphers Laying Food, per 1b., 3 cents; in 100 -lb. sealed bags, per $100 \mathrm{lbs} . \ldots \ldots \ldots .2 .50$

Cyphers Scratching Food, per lb., 3 cents; in 100 -lb. sealed bags, per 100 lbs........2.25

Cyphers Shreded Alfalfa Meal, per 1b., 5 cents: per $100 \mathrm{lbs} \ldots \ldots \ldots \ldots \ldots \ldots \ldots \ldots . . . \ldots 0$

Cyphers Nodi Charcoal, in 2-1b. cartons, 15 cents each; in $50-1 b$. bags, each........ 2.00 Comes in three sizes.

\section{Cyphers Full Nest-Egg Food}

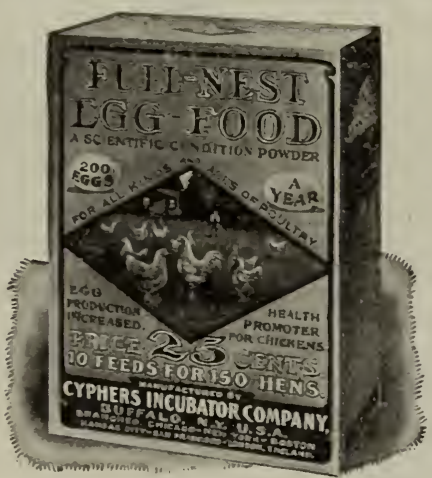

42 ounce package, each............\$ $\$ .30$ 25 pound pail, each................ 2.50

\section{Cyphers Lice Powder}

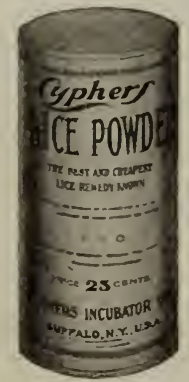

5 ounce package, each .$\$ 0.10$

15 ounce package, each ............. .25 48 ounce package, each ............. .50 100 ounce package, each .............. 1.00

\section{The Cyphers Safety Brooder Stoves}

These stoves positively have no equals. We have them manufactured in lots of three thousand, hence can offer them at very low prices, quality and weight of materials considered. No other

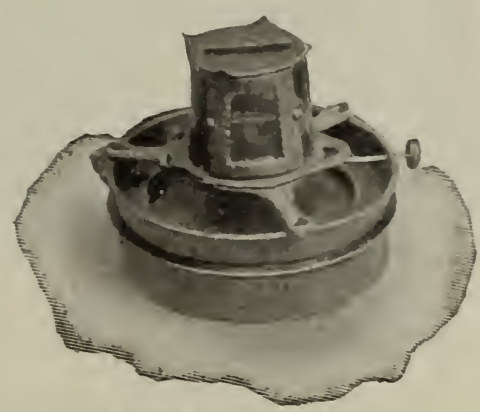

brooder stove on the market has as large a waterjacket or holds as much oil. The water-jacket on the Cyphers Safety Brooder stove holds fully a quart of water, and extends out over the entire surface of the oil bowl, thus placing a sheet of cold water an inch to an inch and a half in thickness between the oil bowl and the flame jets. By this arrangement all danger of the generation of explosive gases, arising from the top oi the lamp or the burner becoming heated, is removed, and we have a brooder stove that can be relied on. We sell hundreds of these stoves each year to persons who wish to build home-made brooders. We strongly advise against anybody using a common lamp in a brooder. The Cyphers Brooder Stove furnishes twice the heat of an ordinary brooder lamp, and lamps are far from being safe. Cheap lamps are equipped with cheap burners, which gum up, smoke, and thus endanger the chicks.

These stoves are used in all the Cyphers brooders.

Price each, \$1.50.

\section{Cyphers Drinking Fountains}

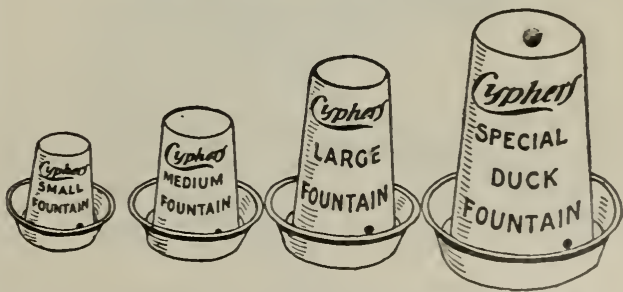

The Cyphers Galvanized Iron Dringing Fountains embody every good feature of a down-todate drinking fountain, and are belleved to be the best in use. They have done much to supplant the old-style earthenware fountains, which could not be thoroughly cleaned and purified. A foun- 


\section{POULTRY SUPPLIES-Continued}

tain that cannot be easily and readily cleaned out, and in which water soon becomes sour, is highly objectionable. A fountain that will burst if the water in it freezes is also an annoyance and a source of loss. The fountains shown herewith are easily filled, easily cleaned, and kept clean. The interior of these fountains can, after being scalded, be exposed to the sun, and thus sweetened and kept wholesome. If placed in the shade in summertime, the water will keep very nearly as cool as in an earthen vessel. They are much lighter. than the earthenware fountains, and a dozen can be put in a compact and cheap package for shipment.

\section{PRICES.}

Small, each, 25c

Medium, each, $40 \mathrm{c}$

Iarge, each, 50c

\section{CyPRER' WAII FOUNTAINS.}

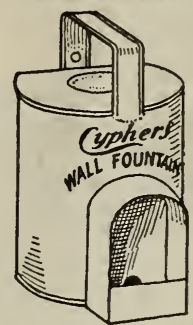

These fountains are something new and extra serviceable in' the way of poultry fountains. One side of the back is flattened so that it can be hung on the wall of a building, or against an upright post or board at any height. A galvanized-iron hood projects over the water trough and protects the water f rom becoming soiled.

These: fountains are made of the best galvanized iron and guaranteed to last many years with proper treatment. We recommend them as first class in every particular. They are made in two sizes.

\section{Prices of Cyphers wall Fountains}

1-Gal. size, each $\ldots \ldots \ldots \ldots \ldots \ldots \ldots \ldots \ldots .75$

\section{Cyphers Food and Water Holders}

\section{Patented}

This undoubtedly is the best device of the kind on the market. They are made in one, two, and three gallon sizes, and are recommended both as food and water dishes. The tops and bottoms of these holders are separable by placing the palm of the hand on top of the upright post, slipping the lingers under the iron brace that is fastened to the upper metal pan, then pressing downward, causing the wires to separate, thus releasing the lower pan.

These wires prevent the chicks or fowls from getting into the pans and soiling the food or water.

Where these holders are used, a saving of 15 to 25 per cent may be counted on in the soft food used. Where food of this kind is thrown on the ground or upon boards, there is considerable waste, and this waste should be avoided. It is clear loss, and every bit of it comes directly out of the profits.

Prices: 1-gal. size, 75c; 2-gal., \$1.00; 3-gal., $\$ 1.25$.

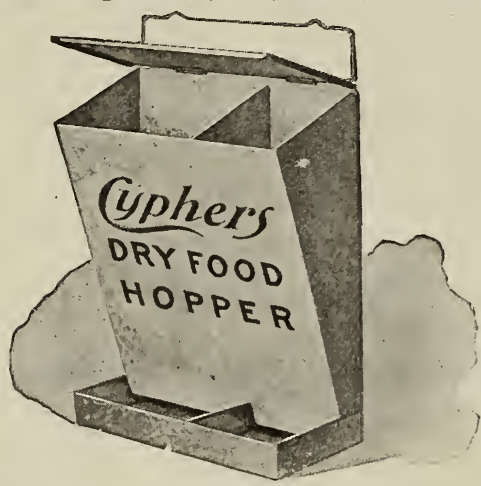

Cyphers Dry-Food Hopper is a practical labor and food-saving device for feeding dry grain food, either whole or ground. Its use reduces the amount of labor on the poultry farm to a minimum. These hoppers. are well made of heavy galvanized iron, are practically indestructible and will last a lifetime with ordinary usage.

Price of Cypers Dry-Food Hopper, \$1.00.

\section{High Protein Beef Scraps}

The Standard Meat Food For Poultry of all Ages.

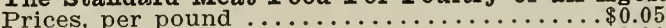

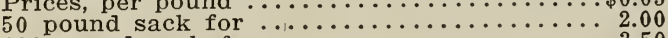

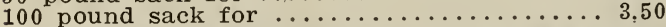
International Poultry and Stock Food 25c and 50c per Package. Pails, \$3.50 Each.

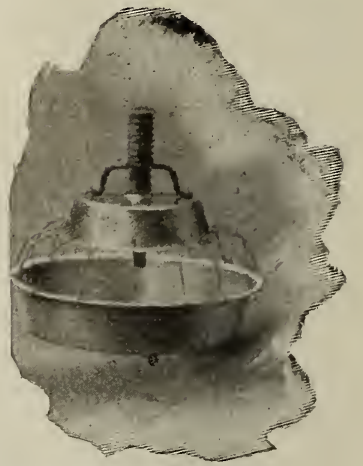

Cyphers Grit and Shell Box

Necesrary on every well-organized Poultry Plant

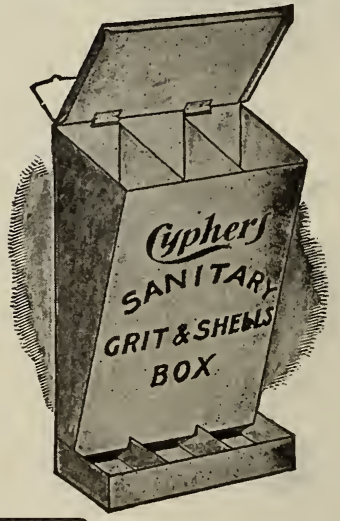

Cyphers Sanitary Grit and Shell Boxes work a material saving in grit, oyster shell, ground bone, charcoal or poultry foods. They are thoroughly practical selffeeding boxes, well made out of heavy galvanized iron and are practically indestructible. This style of box is made with three compartmentsfor grit, oyster shell and charcoal - but where a small flock is kept may be made to serve the purpose of a dry-food hopper.

Price of Cyphers Sanitary Grit and Shell Box, each $75 \mathrm{c}$.

\section{Dairy Association Co's}

Kow Kure, at $50 \mathrm{c}$ and $\$ 1.00$ per can.

Garges Cure, at $50 \mathrm{c}$ per package.

Horse Comfort, at $25 \mathrm{c}$ and 50 per package.

Bag Balm, at 50c per package. 


\section{POULTRY SUPPLIES-Continued}

\section{The Safety Brood Coop}

Hundreds of people, women especially, are so situated that they can not build for themselves or have built, except at unreasonable cost, safety brood coops for hens with chicks. To meet this demand, Mr. Cyphers has devised the Cyphers Safety Brood Coop, illustrated herewith. These coops are well made in every respect, light and handy to move around, and when closed for the night, are safe against varmints of various kinds. They also have a detachable floor, which makes it very convenient to clean out. In dry weather the floor may be left off, and the old hen can be on the ground.

These coops are $20 \times 30$ in size.

Price, $\$ 3.00$.
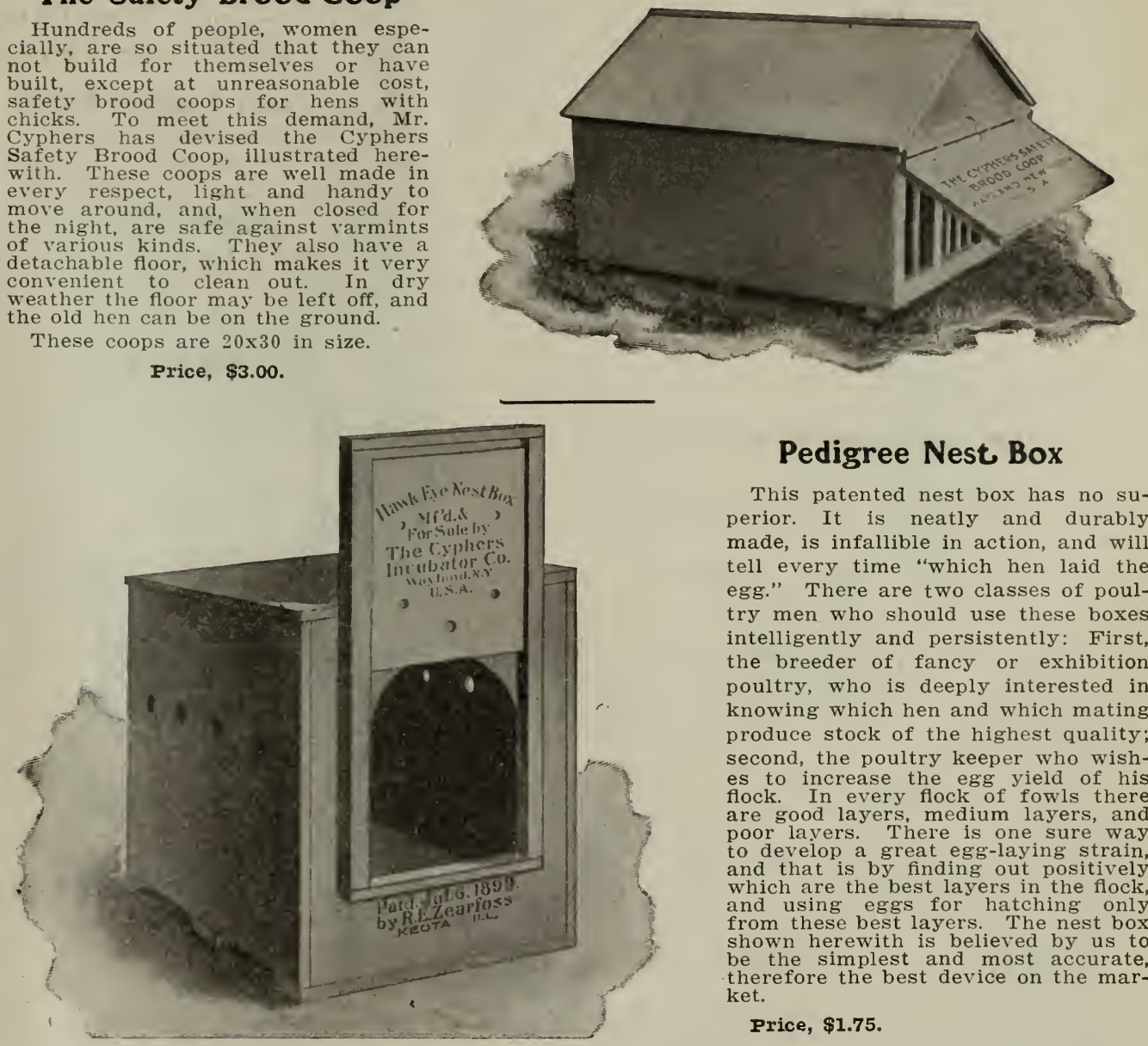

\section{Pedigree Nest Box}

This patented nest box has no superior. It is neatly and durably made, is infallible in action, and will tell every time "which hen laid the egg." There are two classes of poultry men who should use these boxes intelligently and persistently: First, the breeder of fancy or exhibition poultry, who is deeply interested in knowing which hen and which mating produce stock of the highest quality: second, the poultry keeper who wishes to increase the egg yield of his flock. In every flock of fowls there are good layers, medium layers, and poor layers. There is one sure way to develop a great egg-laying strain, and that is by finding out positively which are the best layers in the flock, and using eggs for hatching only from these best layers. The nest box shown herewith is believed by us to be the simplest and most accurate, therefore the best device on the market.

Price, \$1.75.

\section{Ovinapthol Nest Eggs}

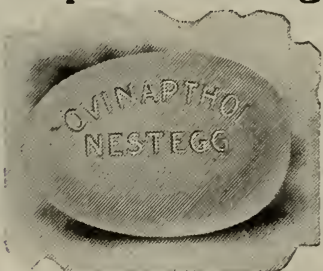

LICE DESTROYER AND NEST EGG COMBINED.

Prices: Each, 10c; per dozen, 90c.

\section{Spring Lever Poultry Punch}

If you keep a record of your chicks of the different breeds, hatches, strains, etc., there is no better, quicker or easier way than by using the RELIABLE SPRING LEVER POULTRY PUNCH for marking the web between the toes. Hundreds of private marks can be made when your chickens are hatched, and a record kept, so that they can flock together until maturity, and then be separated by these marks.

Price, post-paid, 35c each.

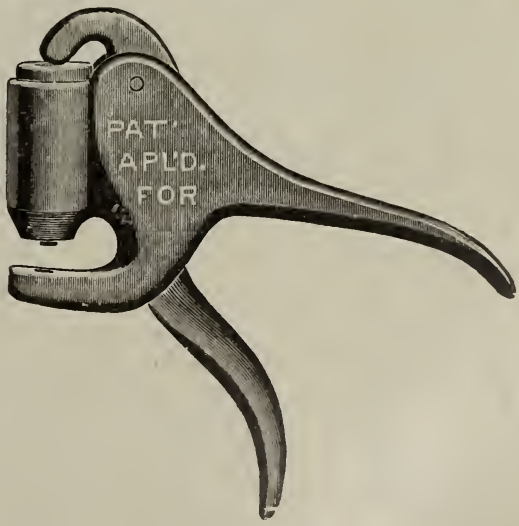




\section{POULTRY SUPPLIES---Continued \\ Cyphers Pure Sulphur \\ Fumigating Candles}

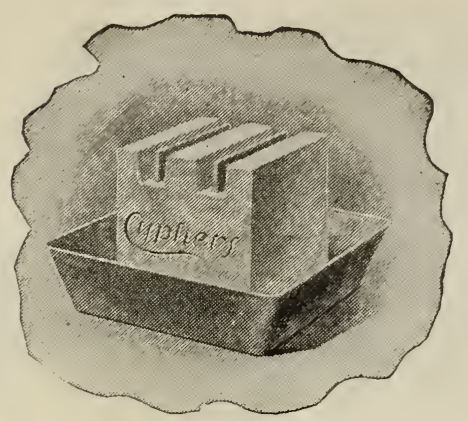

Prices of Candles-Complete with tin dish, each $15 \mathrm{c}$; if postpaid $25 \mathrm{c}$.

\section{Extra Parts and Supplies for Incubators and Brooders}

CYPHERS INCUBATOR TRAYS

No. 0, 60c; No. $1, \$ 1.00$; No. 2, per pair, $\$ 1.50$; No. 3 , per pair, $\$ 1.75$.

\section{INCUBATOR IAMP BURNERS.}

Large size, 80 cents each by mail.

Small size, 60 cents each by mail.

\section{CYPHERS INCUBATOR IAMPS}

(Seamless Bottoms)

Large size, with burner and wick all complete, for use on Nos. 1, 2 and 3 Incubators, $\$ 1.25$ each. Small size, all complete, for use on No. 0 Incubator, $\$ 1.00$ each.

\section{IAIMP WICKS.}

For incubator lamps, 30 cents per. dozen by mail.

For brooder stoves, 30 cents per dozen by mail. New Cyphers Fire-Proof Feater, for any size Incubator, $\$ 3.50$ each.

New Felt Diaphragms, for No. 0 or No. 1, 75c; No. 2 or $3, \$ 1.00$ each.

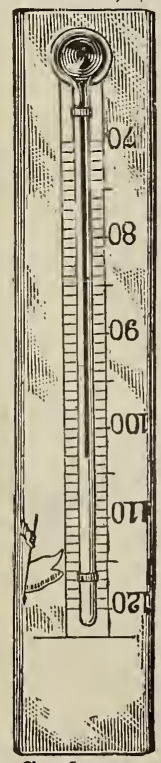

Cyphers Brooder Thermometer

\section{HIGH GRADE TESTED THERMOMETERS}

The best incubators and brooders manufactured are worthless unless the thermometers therein are correct. Hatches fail in incubators because of inferior thermometers, and large numbers of chickens are lost in brooders, owing to defective or worthless thermometers. The operator must know accurately the temperature in the egg chamber, and be sure that the chicks in brooder have the proper amount of heat. The thermometers here listed are guaranteed by the manufacturers to be thoroughly and expertly tested before they are offered to the public.
These can be purchased separately where the customer wishes to do his own wood work one brooder, however, will need to be ordered for pattern, as we do not furnish plans.

Complete outfit for Style B, Indoor or Style A, Outdoor, $\$ 7.00$

\section{Wilbur's Egg and Poultry Food} Wilbur's Seed Meal Stock Foods

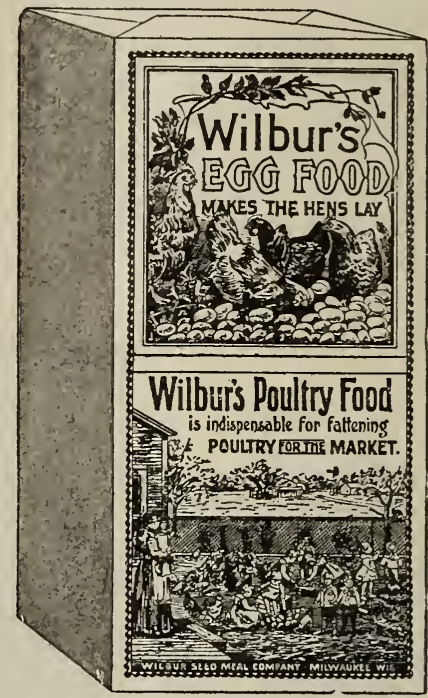

The old and reliable preparation.

Package, 25c and 50c each.

\section{Pratt's Poultry Food}

26 oz. package for $25 \mathrm{c}$

$5 \mathrm{lb}$. package for $60 \mathrm{c}$.

\section{Pratt's Animal Regulator}

Package, 25c, 50c, $75 \mathrm{c}$ and $\$ 1.00$.
Incubator Thermometer, without wire......75c

Hangs from the top of egg chamber so 1 t touches the eggs.

Brooder I'hermometer, unmounted .......60

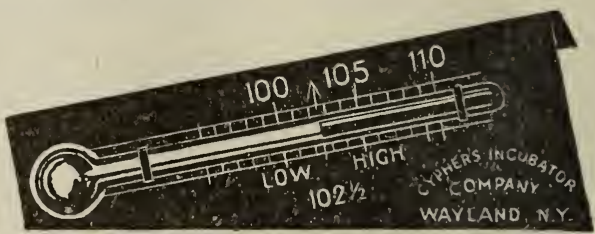

Cyphers Incubator Thermometer.

\section{CAPONIZING INSTRUMENTS}

Poultry men, farmers included, can double their poultry profits by caponizing the surplus cockerels. The operation is simple, the instructions, sent free being so full and explicit that any man or woman, after a careful reading, will be able to perform it. Caponizing is highly successful in every point of view. The demand for capons East and West regularly exceeds the supply, the price per pound averaging more than twice as much as that paid for ordinary roosters. The object of caponizing is to increase the weight of the fowl, and to render the flesh far more tender and palatable.

Pilling's Caponizing Outfit, complete, in fancy case, with instructions, $\$ 3.00$, mailed free. 


\section{POULTRY SUPPLIES-Continued}

CXPHERS PEDIGREE TRAYS. To be used in place of regular trays when one wants to keep separate the chicks from certain $\$ 4.50$ pair.

\section{A SELF-OPERATING OT AUTOMATIC SPRAYER.}

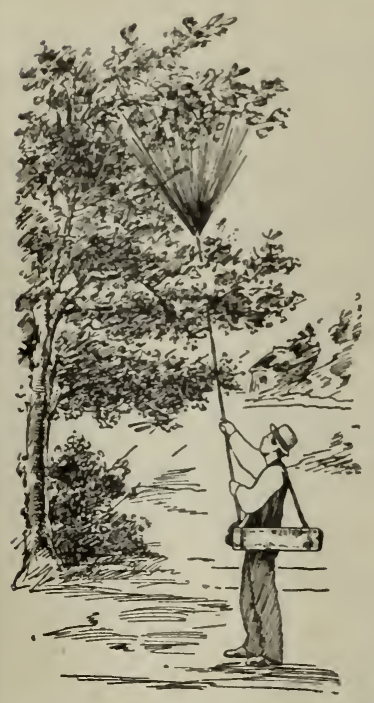

Auto-Spray at work with Extension Pipe for Tall Tress.
This is a fine sprayer for the poultry ralser, always ready for use.

Eight or ten strokes of the plunger in the air-chamber will compress enough air to discharge the entire contents and make a continuous spray for

The AUTO-SPRAY will do the work of five ordinary sprayers, as the operator carries the sprayer over his shoulder, and, as soon as one bush or vine is sprayed, moves on to another, whereas the ordinary sprayer has to be set on the ground, and the operator has to stop to do the pumpTHINK OF THIS LOSS OF TIME. For greenhouses, either for giving plants a showerbath or for applying insecticides, you need an AUTOSPRAY.

\section{CAN BE USED}

As a fire-extinguisher.

For spraying carbolic acid, to prevent hog cholera.

For spraying insecticides and whitewash in hen-houses.

For spraying disinfectants in hospitals and other places, to prevent the spread of contagious diseases.

For washing windows and wagons. fully five minutes. ing for each separate bush.

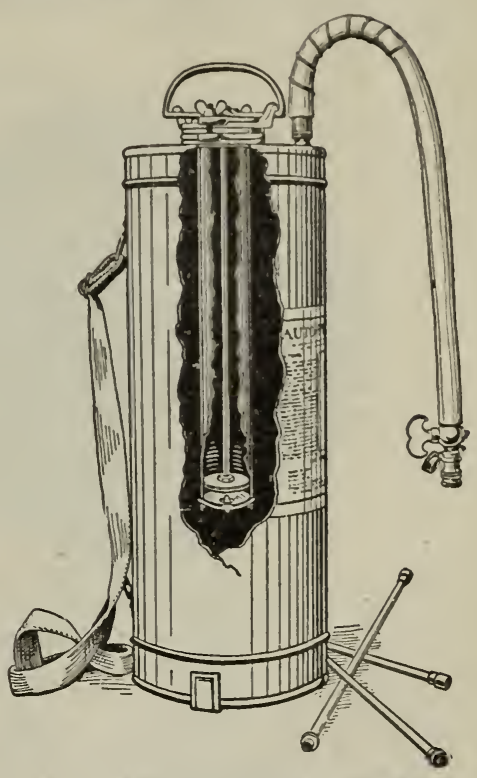

Auto-Spray showing Working Parts.
As a sprinkler for plants and flowers.

the valves; they all can be taken apart in a few

For sprinkling floors, taking the place of wet seconds, without the use of a tool of any kind. For sprinkling floors, taking the place of wet The working parts are all brass; can not get out sawdust or the common sprinkler.

Make note of the simplicity of construction. See it is air and water tight. You can spray with the plunger rod, the patent fastener at the top, your good clothes on.

\section{PRICE OF AUTO-SPRAY.}

\section{EXTENSION PIPES.}

Galvanized steel, all working parts brass, with 2-foot, 3-ply rubber hose, stop-cock, 1 fine, 1 coarse and 1 solid stream nozzle, and shoulder strap, $\$ 5.50$.

Brass Tank, with same parts as described above; price, $\$ \$ .50$.

Size.-The above sprayers are 2 feet long and 7 inches in diameter; weight, empty, 7 pounds. Capacity, about 4 gallons.

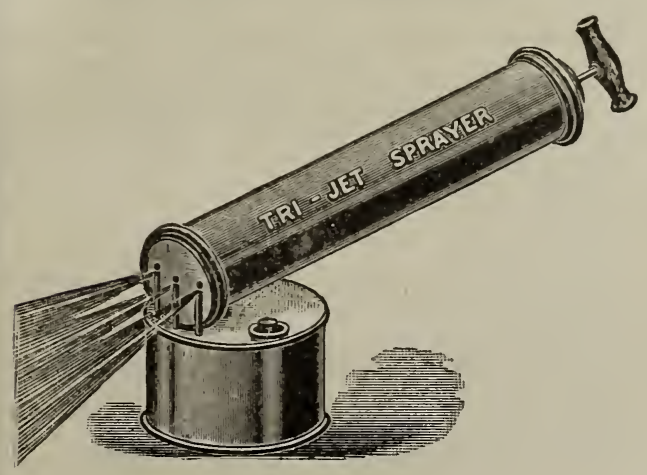

For spraying tall trees, we furnish extension piping in 24-inch lengths, each fitted with brass couplings. Two or thre sed.

Galvanized, 30c.

\section{New Era Tri-Jet Sprayer}

\section{Tin; price, $75 \mathrm{c}$.}

For spraying vines, shrubs, plants and cattle (to keep off flies), and the interior of henneries, will save the price of the sprayer in a single day's use.

This sprayer embodies the principle of the ordinary atomized, and is new only in the application of same to a new use. The advantages are at once apparent to the user. It is the most economical, not only because of its low price, but because of its great saving of material. The saving in one day's use of spray will pay the first cost of the sprayer.

One quart of liquid in this atomizer will cover more effectively a larger surface than ten quarts in the common sprayer or sprinkler. It is a great saving in labor, because, when loaded, it weighs much less than any other, and because the spray is easily made to reach six feet from the operator. A careful comparison of the New Era Tri-Jet 


\section{POULTRY SUPPLIES--Continued}

Sprayer, point by point, with other hand sprayers, is all that is needed to convince a man that it is "the best hand sprayer made.'

Why the New Era Sprayer is better than others of similar construction:-

1. Because the reservoir is galvanized iron, and will not corrode or rust.
2. Because the feeding tubes are zinc, and will not corrode or rust.

3 . Because the plunger is backed and reinforced by wood (not metal).

4. Because it has three openings and three times the capacity of the ordinary single-jet sprayer.

5. Because the sprayer is larger, and will spray further.
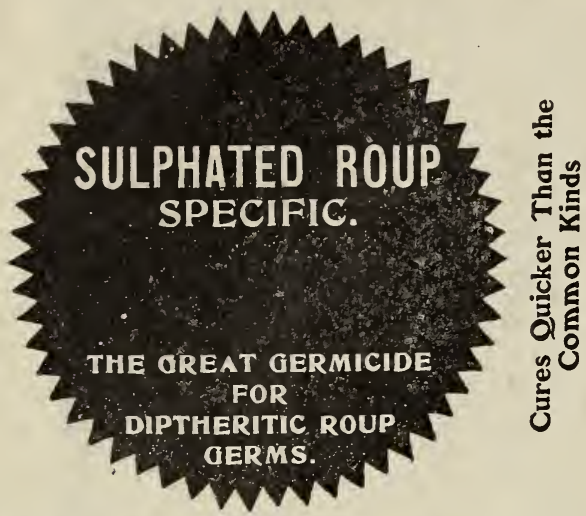

\section{SEATOI SUIPFATED ROUP SPECIFIC}

The Great Germicide.

This specific not only cures roup in its worst form, but eradicates all the poisonous impurities from the system.

Should your fowls have cholera, cure them by using the specific same as for roup. When in need of a roup or canker cure, buy the best,-buy Sulphated Roup Specific.

Put up in 50c packages; by mail, 60c. Easy to use; simply put in drinking water.

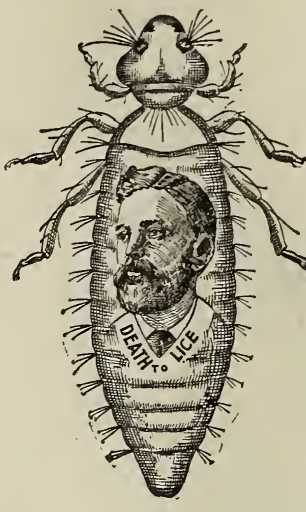

Lambert's Death to Lice Remedies

POWDER.

For body lice on sitting hens, laying or exhibition poultry. It does not injure eggs or chickens, or soil the plumage in any way. It is also invaluable for lice on horses, cattle or plants, ticks on sheep, moths in carpets or furs, fleas and lice on dogs, cats and pets. Also a valuable disinfectant. Price, 5-oz. box, $10 \mathrm{c}$; 15-oz., 25c; 48oz., $50 \mathrm{c} ; 100-\mathrm{oz} ., \$ 1.00$.

\section{OINTMENT.}

For lice on chickens. Scaly shanks on fowls. $10 \mathrm{c}$ and $25 \mathrm{c}$ per box, post-paid.

\section{SPECIAI.}

In powder form for dissolving in kerosene as a liquid louse killer, or to add to whitewash for mites and spider lice. 4-oz. box, $10 \mathrm{c} ; 16-0 \mathrm{z}, 25 \mathrm{c}$.

If Powder or Special is to be sent by mail, 1c per ounce must be added for postage.

\section{SEATTLE FLY KNOCKER}

\section{Guaranteed}

Fly Knocker instantly drives away flies, mosquitoes, and insects from any animal sprayed with the magic liquid.

Cows feed quietly all day, and give one-third more milk.

Stock cattle will fatten better, and larger profits are realized.

Horses will work easier and rest quieter, being absolutely free from annoyance, for no insect will go near where Fly Knocker is used.

Will also prevent the gadfly from striking sheep and causing "grub in the head."

To protect animals from flies and mosquitoes, apply once or twice a day lightly over the animal with a sprayer, giving special attention to the legs, head and sides. It is better to give a light application frequently than a heavier coating at long intervals.

The feed saved will more than pay the cost of the remedy, and you do not have to wait until after dark to milk your cows.

By the use of Fly Knocker your cow will give one-third more milk; your horse will rest during rest time and work during working hours on twothirds the feed it now requires, and will be free from vermin of all kinds.

Guaranteed to do the work, or money refunded.

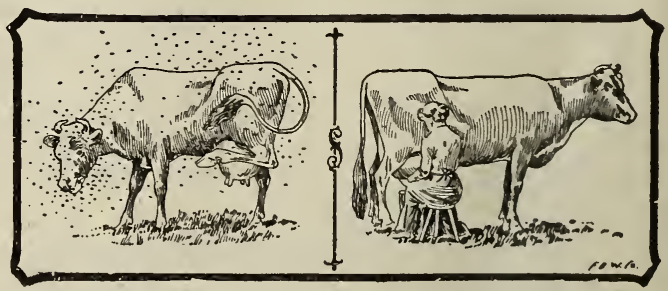

Which cow would you rather milk?

NO USE MIIKING COWS AFTER DARK. PRICES.

Half-gallon cans ...............\$0.75

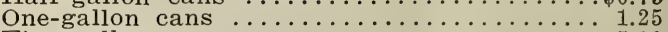

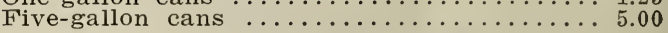

It costs about $1 / 2 \mathrm{c}$ per day per animal to use.

To apply Fly Knocker economically, use our New Era Sprayer. (See page 47.)

ODORIESS FERTIIIZER for house plants, per lb., $10 \mathrm{c}$; by mail, post-paid, 20c per lb.

For other fertilizers for flower borders, lawns, garden and farm use, write for prices, stating kinds (or purpose) and quantities required. 


\section{POULTRY SUPPLIES-Continued}

\section{Bond's Grit Machine}

The best Grit Crusher manufactured. A machine that will crush enough in a few minutes to last a hundred head of rowls a month. It is so simple that any child can use it. It works with a lever power and takes very little work to run it.
You can crush granite, oyster and claim shells and crockery. After you have purchased one you will wonder liow you did without it so long. The sight of the machine sells it. One customer invariably brings another.

\section{The Price is Only $\$ 4.00$}

\section{MANN'S GREEN BONE CUTTERS}

If you want an old reliable machine-one that has established a reputation in the yards of practical poultrymen-buy-a Mann's.

If you want a new machine-one that has every late improvement, one that is really "ahead of the times"-buy a Mann's. It does the work with the greatest ease. It makes every hen a paying hen. Try it and see.

The Mann's is the only machine which has a self-governing feed, which produces a uniform pressure against the knife, whether the bone be hard or soft. You set the machine to suit your strength, and it never requires more power than you set it for.

The Mann's cuts any bone and all adhering meat or gristle, and never clogs or stalls.

The Mann's is, in short, an ideal bone cutter. We believe that it is a better machine, all points considered, than that produced by any other manufacturer.

Try one for yourself, and if you are not satisfied you can have your money back. Could you ask more?

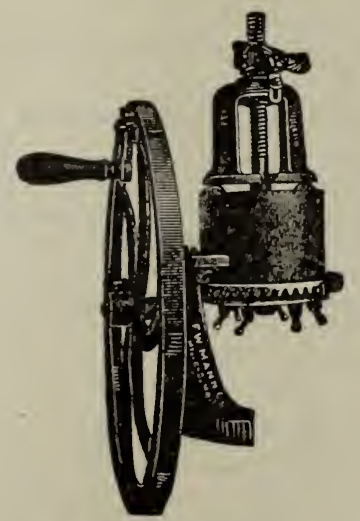

MANN'S No. 5 .

Has four knives, large cylinder, and has the latest patent, automatic, governing spring feed, which makes it ane of the best, low-priced bone cutters ever offered. Can furnish with crank, balance wheel, or mounted on iron stand.

MANN'S No. 7.

The New No. 7 is mounted on strong iron stand, and has patent automatic governing spring feed. Large, open-hinged cylinder, giving instant access to all working parts, has six knives, geal guard, anti-clog device, heavy balance wheel and other improvements.

MANN'S NO. $71 / 2$.

Adapted to run either by hand or by power, without any change.

The particular advantage of the No. $71 / 2$ is that while it is a complete power machine, it can be operated by hand just as easily as the No. 7. Thus, it is always ready for use. It is recommended even if you have no power at present, for should you get power in the near future, you need be at no further expense. There is a large class that need a power bone cutter, who cannot rally afford to pay the price of the No, 11 or No. 12. The No. $71 / 2$ will appeal directly to this class. It has all the improvements. It meets a long-felt want.

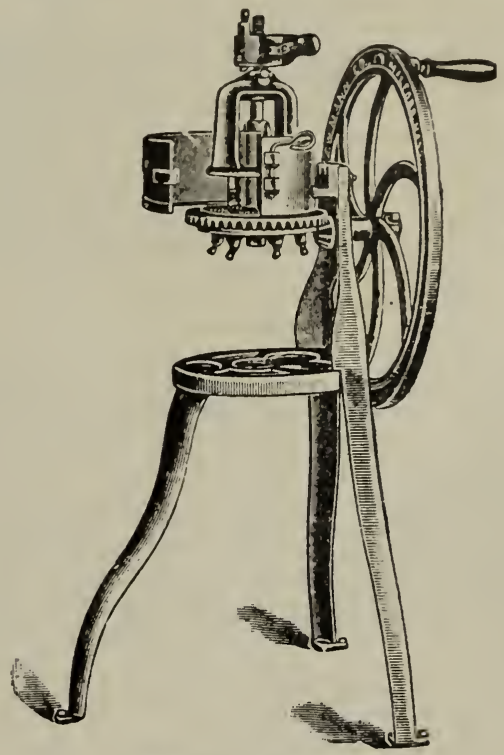

MANN's NO. 7

MANN'S No. 9.

The description of No. 7 will apply to the New No. 9. The difference consists of larger cylinder, greater holding capacity, different design and larger table.

\section{MANN'S NO. 11-HAND OR POWER.}

Intended for large flocks when the machine must be run by hand a portion of the time. It is really a semi-power and semi-hand or combination machine, and as such has its place. The No. 11 is exactly the same as No. 9 with the power parts added. It has all the late improvements, special feed, anti-clog, open cylinder, tight and loose pulleys, etc. Capacity, 100 lbs. per hour.

\section{NO. 12, POWER.}

This machine deserves more than passing notice. It costs but $\$ 4.00$ more than the semipower, or No. 11, yet is heavier, stronger, better and far more durable. It is strictly a power machine, and full of business from top to toe. Remarkable for strength, capacity, simplicity, eronomy and convenience. It has all the new patented improvements. In addition, this cutter has a grab clutch, an important and novel device by which it can be started and stopped instantly. No slipping of belts. The balance wheel runs all the time with the pulley, consequently the clutch per ates instanty. per hour. Horse power required, any one who has large quantities of bone to cut. 


\section{POULTRY SUPPLIES-Continued}

\section{PRICE IIST OF MANN BONE CUTTERS}

New Styles.

No. $5 \mathrm{C}$ (with crank handle) ... 7.75

No. 5 B (with balance wheel)....\$10.00

No. 5 B M (B. W. and iron stand) 13.00

No. 7 (B. W. and iron stand).... 15.00
No. $7 \frac{1}{2}$ (hand or power)....... 21.00

No. 9 (B. W. and iron stand) ... 22.00

No. 11 (power machine)......... 30.00

30 No. 12 (power machine)......... 34.00

55 No. 15 (power machine).........6.66.00

80 No. 4 B (with balance wheel).... 12.00

107 No. 4 B IM (B. W. and iron stand) 14.00

\section{LEG BANDS FOR POULTRY}

We have examined and tried every band, and believe we list the three best kinds.

\section{THE SMITH SEALED LEG BANDS}

The modern method of marking poultry is to use a band that, "when once on, is always on," as one customer puts it. These bands, though only introduced last season, are attracting more attention than anything in the line of markers yet offered the poultry fraternity.

Our bands are made of aluminum, and so constructed that by simply crushing a soft rivit they are sealed on the bird's leg, and must be destroyed to be removed. Birds placed on exhibition, bought or sold under score cards, should always wear the SMITH SEALED BAND, as they are a positive guarantee that the band and bird wearing it are the identical specimens that the judge handled when he signed the score card or awarded a prize. Just look back over your old score cards, and see if you ever bought or sold a specimen that could be identified from the card and band it wore.

When a bird wins a prize, or is scored and offered for sale, under score or award card, the only way buyers can be sure they get what the card calls for is to insist on having them wear a Smith's Sealed Band, as we make no duplicate bands.

Be sure to remember that our sealed bands are numbered in lettered series of $\mathrm{A} 1$ to $\mathrm{A} 10,000, \mathrm{~B} 1$ to $\mathrm{B} 10,000$, etc., and we only number bands to order when we make them with name, name and address, or initials on, and then do not duplicate former orders, but keep a record of each order, and, when they conflict, either give higher numbers or a serial letter.

In ordering it is best to give breeds and the number wanted for male and females. The bands are made in six sizes, and fit ordinary fowls, as follows:-

No. 1-Bantams and small Mediteraneans. No. 2-Mediterranean females. No. 3-American females and Mediterranean males. No. 4-American males, medium Asiatic females, and hen turkeys. No. 5-Large Asiatics and ordinary tom turkeys. No. 6-Extra large turkey toms and very heavy feathered Asiatics.

\section{PRICES BY IMAIL OR FXPRESS PREPAID.}

10 for $25 \mathrm{c} ; 25$ for $50 \mathrm{c} ; 60$ for $\$ 1.00 ; 100$ for $\$ 1.50$.

\section{ECIIPSE IEG BANDS.}

Require no tool to seal them on.

This new band is an ingenious one. You simply pass it around the bird's leg, and, by pressing the two ends together, lock it. The automatic lock is under the number, and it is imposible for it to come off. These bands are made of aluminum, and are light, strong, neat, durable and perfectly smooth on the inside, making it impossible to injure the bird's leg. Order by number or class, the same as the above bands.

Prices, by mail, post-paid: 12 for 25 cents; 25 for 50 cents; 60 for $\$ 1.00 ; 100$ for $\$ 1.50$.

\section{CIIMAX IFG BANDS.}

These leg bands are nothing new. They are standard leg bands that have been manufactured for years, and have the indorsement of many of the foremost poultry raisers in the country. They are neat, light, durable, secure, and are guaranteed to stay on when once placed on the fowl's leg. They are easily put on or removed. AND NO TOOLS ARE REQUIRED. The rings are made of steel or brass, and are so bent that the tag acts as a clasp, holding them securely in place. We have them in several different sizes for different breeds. Please order as follows, according to your wants: No. 1, for Bantams; No. 2, for Mediterranean females; No. 3, for Mediterranean males and American females; Nos. 4 and 5, for American males and Asiatic females; No. 6, for Asiatic males and turkeys. THEY ARE NOT MADE FOR PIGEONS. Numbers run from 1 to 100 , from 100 to 200 , and so forth up to 1,000

\section{PRICES OF CIIMAX IEG BANDS.}

12 for $25 c$; 25 for $40 c$; 50 for $75 c ; 100$ for $\$ 1.35$. Post-paid.

\section{HEXAGON POULTRY NETTING}

For poultry and Ornamental Fencing, Chicken Iuns, Pigeon Iofts, Aviaries, Guards for Windows, Trellises, Etc.

No. 20 wire. In rolls 150 feet long, in the following widths:-

1 in. Mesh.

18 inch $\ldots \ldots \ldots \ldots 3.75$ per roll 24 inch .......44.50 per roll
2 in. Mesh. $\$ 2.00$ per roll 2.10 per roll

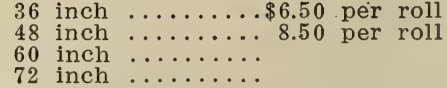

$\$ 2.85$ per roll 3.50 per roll 4.25 per roll

5.00 per roll

Short lengths, 2-inch mesh, 1c square foot; $1 \frac{1}{2}-$ inch mesh, $1 \frac{3 / 4}{\mathrm{c}}$ square foot; 1 -inch mesh, $2 \frac{1 / 2}{\mathrm{c}}$ square foot.

Prices subject to change without notice. 


\section{POULTRY SUPPLIES-Continued}

\section{UNION LOCK POULTRY FENCE}

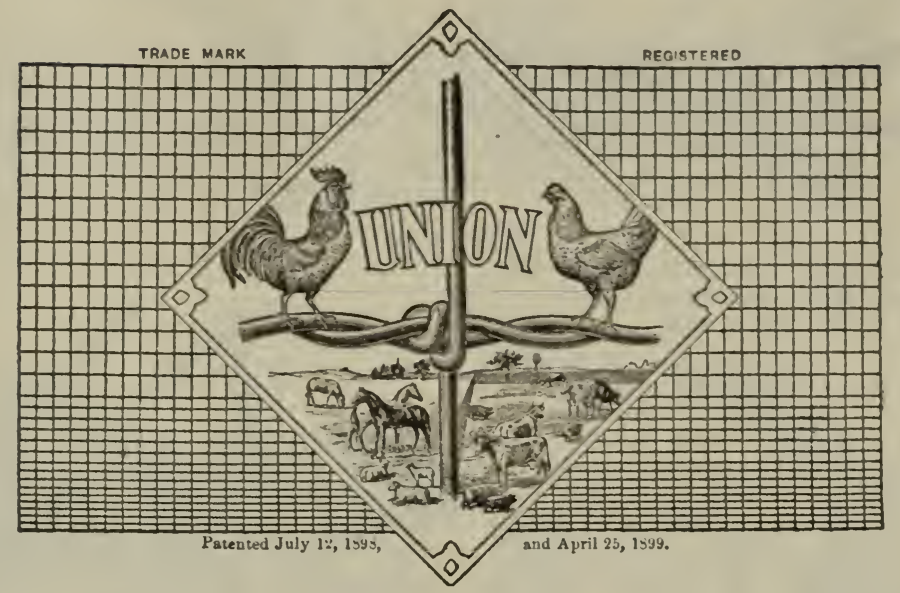

The horizontal lines of this fence are composed of two No. 20 galvanized steel wires twisted together. Beginning at the bottom the first seven cables are $1 \frac{1}{4}$ inches apart, the next three cables are $1 \frac{1}{2}$ inches apart, then six cables 2 inclses apart, and all above that 4 inches apart. 'inis gives a mesh of $11 / 4 \times 3$ inches at the bottom, whero it is needed for small chicks; and above 2 feet, where fowls can only reach when on the wing, the mesh is $3 \times 4$ inches. The pickets ace No. 19 gaivanized steel wires, and are 3 inches driart. The picket is fastened to the caibs:s "ith the Union Lock, the same as we use in rur Fibld and Hog Fencing, which has given sush excelent satisfaction.

On account of the picket being at right angies to the cables, the fence will fit any uncienness of the ground without cutting, which is an advantage not possessed by any diamond mesh netting or diagonal mesh fencing.

As all the cables are the same length and run the whole length of the fabric, every part can be stretched perfectly. The fence is amply strong, as the breaking strain of a No. 20 two-wire cable is 192 pounds, and there are ten cables in the first foot of fence. Because of its strensth and construction, this fence requires no top or bottom rail and no more posts than the ordinary woven wire stock fence, or about one-half the number needed for poultry netting.

In strength, closeness of mesh, adjustability and economy, it excels all others.

\section{In Bales of Ten Rods-165 Linear Feet}

Per bale.

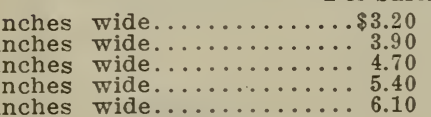

\section{Weight.} 26 pounds FOOT. 32 pounds 41 pounds 48 pounds 54 pounds
SHORT IENGTHS, $11 / 2$ CENTS PER SQUARE

SPECIAI PRICES IN IARGE QUANTITIES. PRICES SUBJECT TO CHANGE WITHOUT NOTICE.

\section{Far-Famed "Planet Jr.," Garden Tools}

These are the most popular and complete garden tools made. They are known the world over, and beyond question are the most perfect in design construction and finish, and most practical yet invented. No wide-awake farmer or gardener can afford to be without them. Space will not permit illustrating and describing all of the "Planet, Jr." tools, but we will gladly send a fully-illustrated catalogue to any who desire it.

DO NOT class the "Planet, Jr.," goods with the many lines of garden tools on the market at a lower price, as there is no comparison when it comes to material and workmanship.

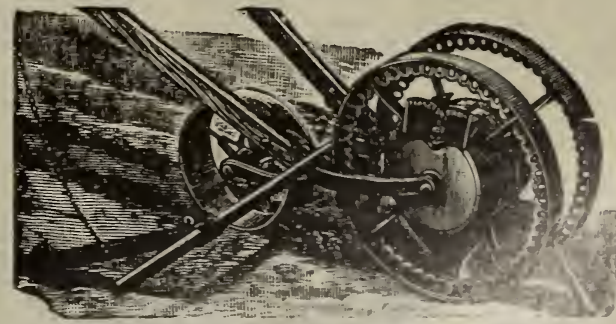

No. 2 Drill Seedar. Price, \$8.00, 


\section{FAR-FAMED “PLANET JR.." GARDEN TOOLS-Continued}

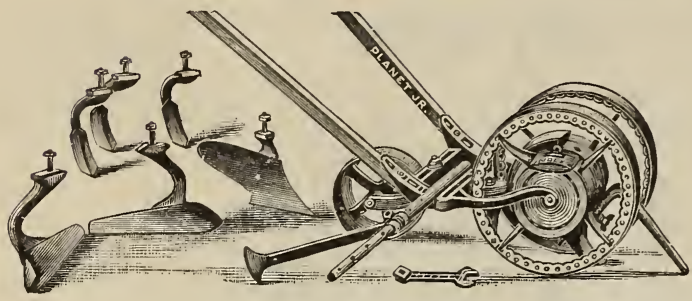

"Planet, Jr.," No. 1, Combined Drill, Seeder and Wheel Hoe, Cultivator and Plow. Price, \$9.50.

This has long been the most popular combined tool made. As a seed sower it is the same as No. 2 Drill Seeder, smaller. From a drill it is changed to its other uses by removing two bolts, when hoes, etc., can be quickly attached. It is an excellent seed sower, a first-class double or single wheel hoe.

A pair of 6-tooth rakes supplied when specially ordered. Price, $\$ 1.00$ extra.

No. 25 Combined Fill and Drill Seeder and Double-Wheel Hoe, Cultivator, Rake and Plow. Price, \$14.

$11 \frac{1}{4}$-inch wheels. Hopper holds $2 \mathrm{r} / 2$ quarts. It practically combines in one tool the No. 4 Drill and and No. 12 Double-Wheel Hoe.

As a drill it is almost identical with the "Planet, Jr.," No. 4 Drill; will sow in drills or hills, 4, 6, 8, 12 or 24 inches apart, and has the same feed, hill-dropping mechanism, and automatic device for throwing out of gear, and the new combined cut-off and seed index, with brass thumbscrew adjustment. It is thoroughly substantial and is accurate in sowing all kinds of garden seeds, in either hills or drills.
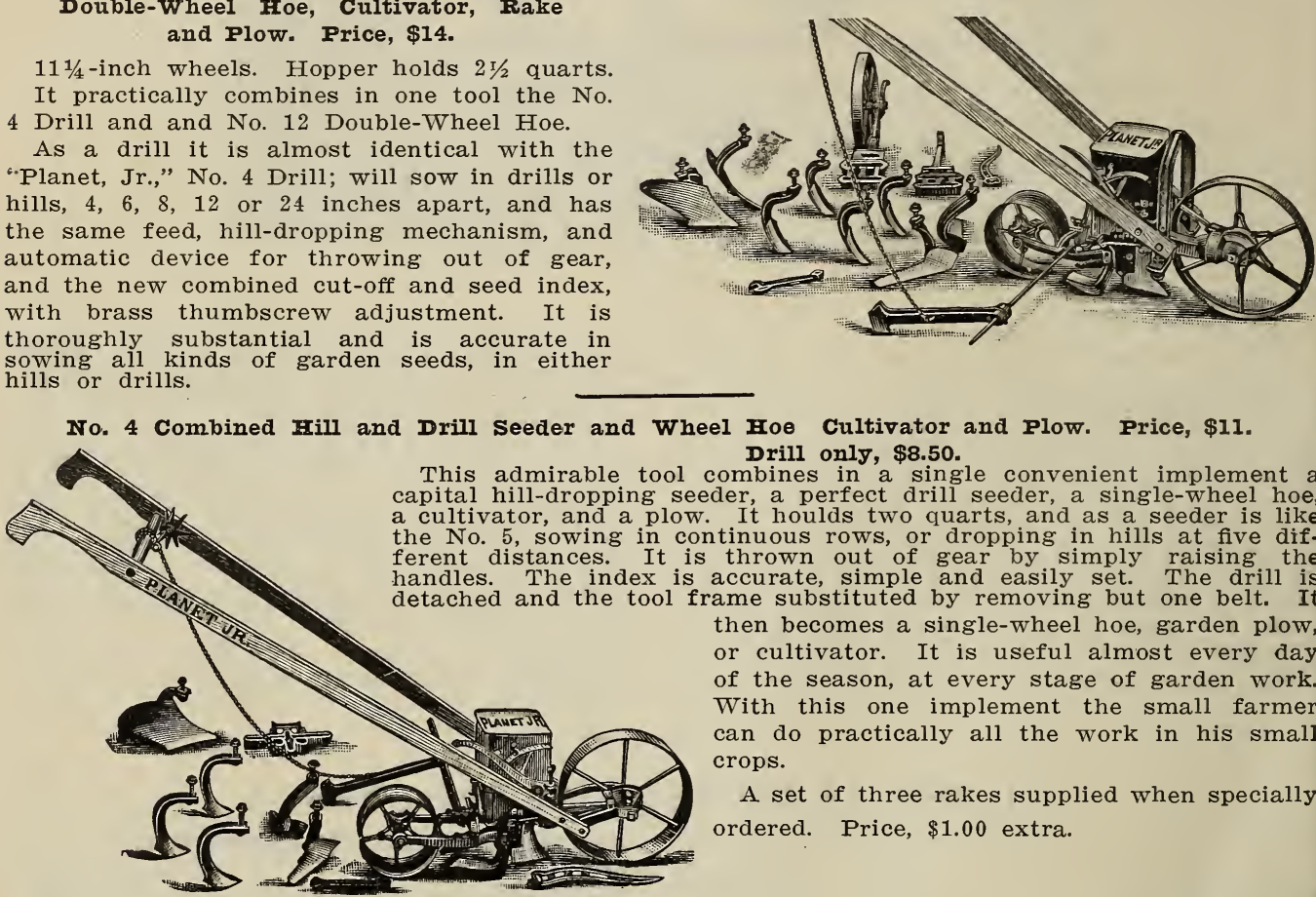

Hoe Cultivator
Drill only, $\$ 8.50$.

Plow. Price, $\$ 11$.

combines in a single convenient implement a capital hill-dropping seeder, a perfect drill seeder, a single-wheel hoe, a cultivator, and a plow. It houlds two quarts, and as a seeder is like the No. 5, sowing in continuous rows, or dropping in hills at five difis thrown out of gear by simply raising the handles. The index is accurate, simple and easily set. The drill is detached and the tool frame substituted by removing but one belt. It then becomes a single-wheel hoe, garden plow, or cultivator. It is useful almost every day of the season, at every stage of garden work. With this one implement the small farmer can do practically all the work in his small crops.

A set of three rakes supplied when specially ordered. Price, $\$ 1.00$ extra.

No. 3 Hill and Drill Seeder. Price, \$11.

Hopper holds three quarts; 15-inch patent steel driving-wheel, with broad face, which makes the drill run easily, even when full. The quantity of seed is regulated by an accurate index, conveniently placed at the top of the handle, and carefully graduated for either hill dropping or drilling. The flow of seed is started or stopped by a single movement of the forefinger. The roller is broad and hollow faced, leaving a wide, smooth track for the wheel hoe. It is extremely simple and will not injure the most delicate seed.
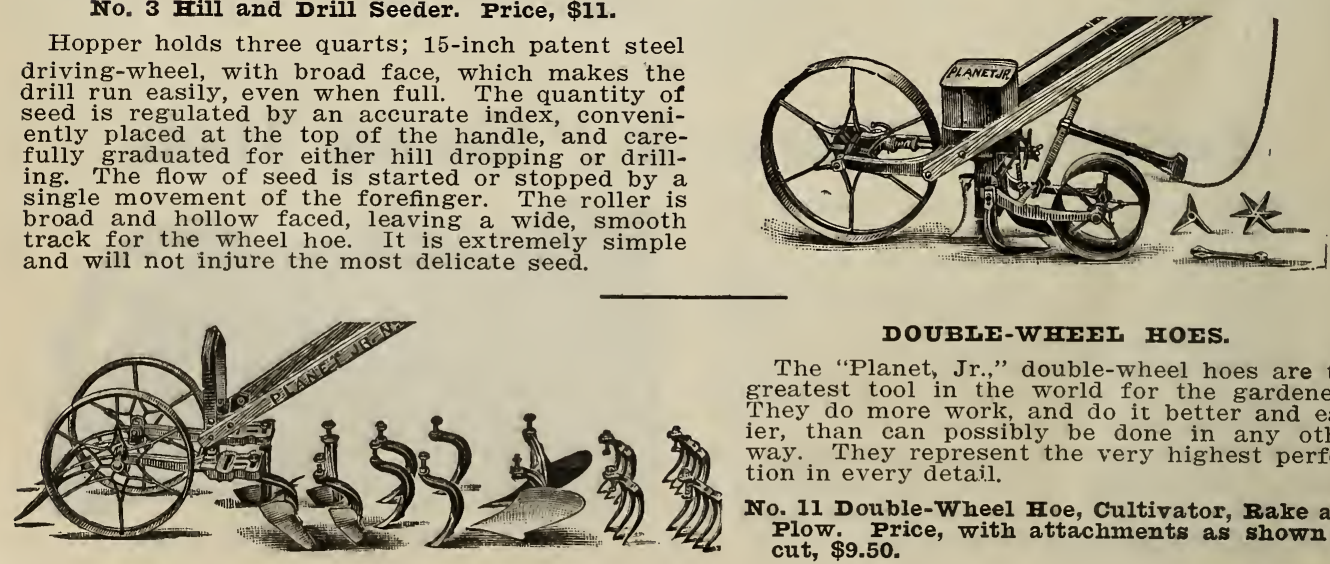

DOUBIE-WHEEI HOES.

The "Planet, Jr.," double-wheel hoes are the greatest tool in the world for the gardeners. They do more work, and do it better and easier, than can possibly be done in any other way. They represent the very highest perfection in every detail.

No. 11 Double-Wheel Hoe, Cultivator, Rake and Plow. Price, with attachments as shown in cut, $\$ 9.50$. 


\section{FAR-FAMED “PLANET JR.," GARDEN TOOLS-Continued}

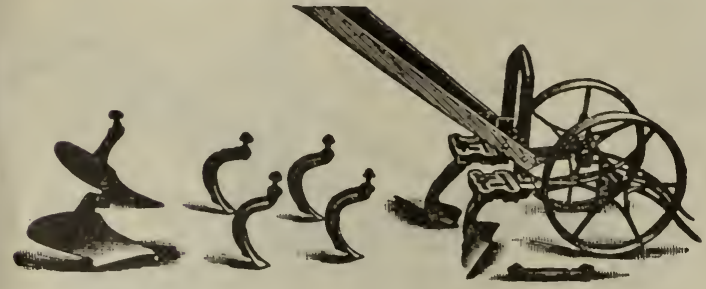

No. 12 Double Wheel Hoe, \$7.50.

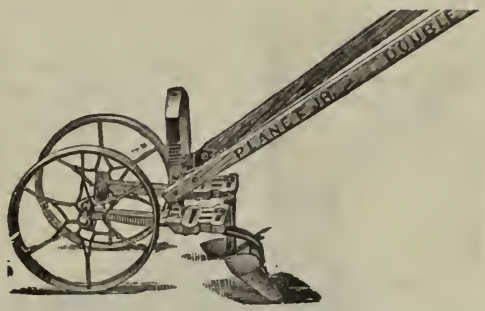

No. 13 Double Wheel Hoe, $\$ 5.50$.

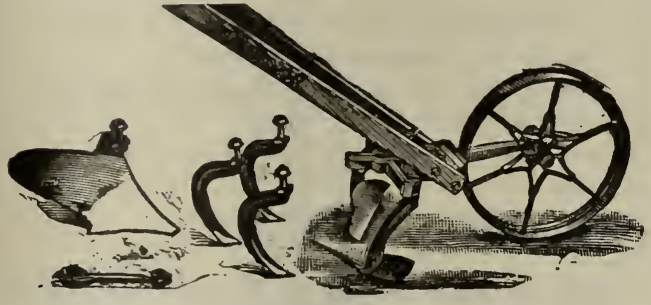

No. 16 Single Wheel Hoe, Cultivator, Rake and Plow. Price, $\$ 6.00$

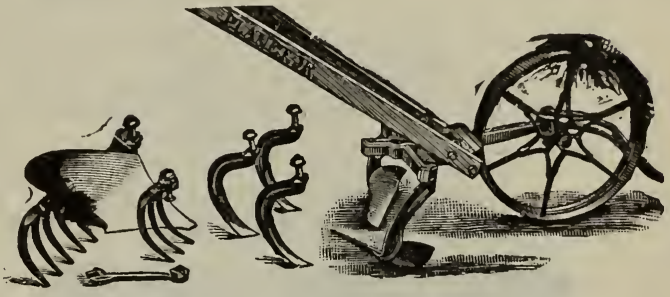

No. 17 Single Wheel Hoe, Cultivator and Plow, as in cut, $\$ 5.50$.

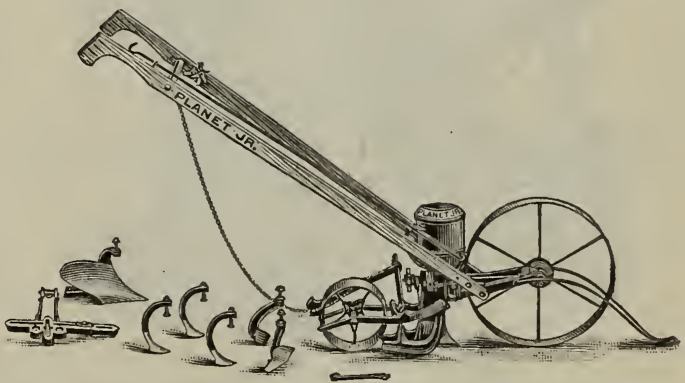

Farmers' No. 19 Single Wheel Hoe, Cultivator and Plow. Price, $\$ 4.50$.

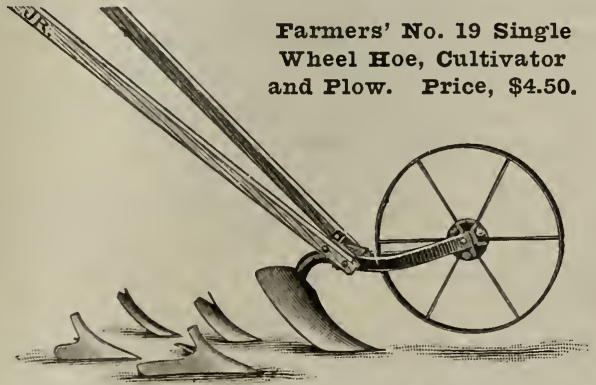

No. 171/2 Single Wheel Hoe and Cultivator. Price, $\$ 5.00$.

This machine is similar to No. 17, except it has no plow, but it has a leaf lifter. Thousands of them are sold annually for cultivating sugar beets and onions.

No. 18 Single wheel Hoe, with pair Hoes only. Price, \$4.00.

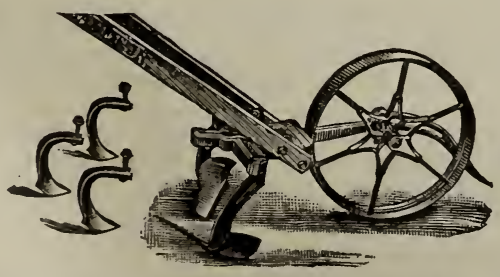

This new and attractive implement is especially designed for the farmer's garden work, though
No. 6 "Planet, Jr.," Combined Hill and Drill Seeder Wheel Hoe Cultivator and Plow.

This latest "Planet, Jr." Hill and drill Seeder and Wheel Hoe has been under construction for two years past, and has been held back until every detail has been made as nearly perfect as it seems possible to have it.

Packed weight, 58 lbs. Price, $\$ 13.50$.

No. 6 "Planet, Jr.," Combined Hill and Drill Seeder, Hoe, Cultivator and Plow. Packed weight, 58 lbs. Price, $\$ 13.50$.

it offers to every one, with either field or garden, a cheap and effective tool for all hand wheel hoe operations. The wheel is high, and is made with stiff steel rim and spokes; the handles may be readily changed to suit man or boy.

The tools are as follows:-

A large garden plow of hard steel, smoothly polished, throwing a neat furrow.

Ten-inch sweep. This is the latest and best pattern; is thin, and is a perfect weed killer.

Six-inch sweep. Same pattern as ten-inch.

Four-inch cultivating tooth. For deep cultivation and for all thorough work

Two-inch cultivator tooth. For still deeper work, and for marking out for onion sets, etc. 


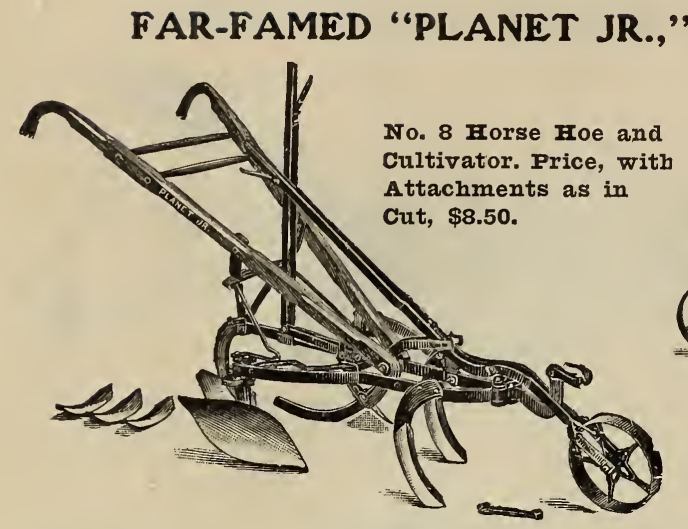

The "Planet, Jr.," Horse Hoe is by far the best machine of its kind on the market. It is adapted to every kind of cultivation and a great variety of work.
GARDEN TOOLS-Continued

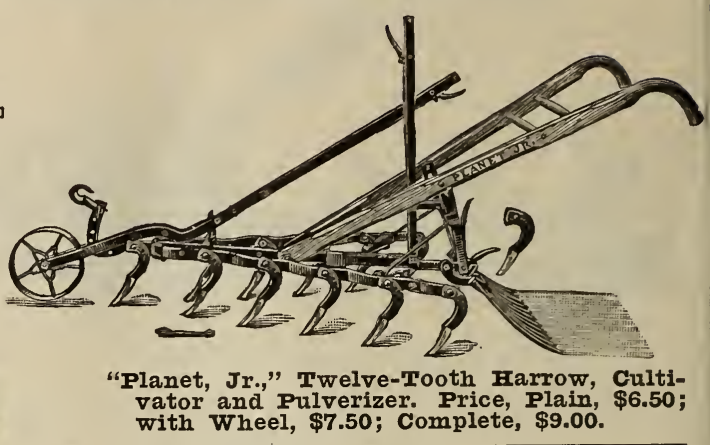

REMEMBER this list is ONIY PART OF WHAT WE CARRY IN STOCK.

Write for our handsome complete Catalogue of "Planet, Jr.," Goods. Free.

\section{THE CLIPPER GRAIN AND SEED CLEANERS}

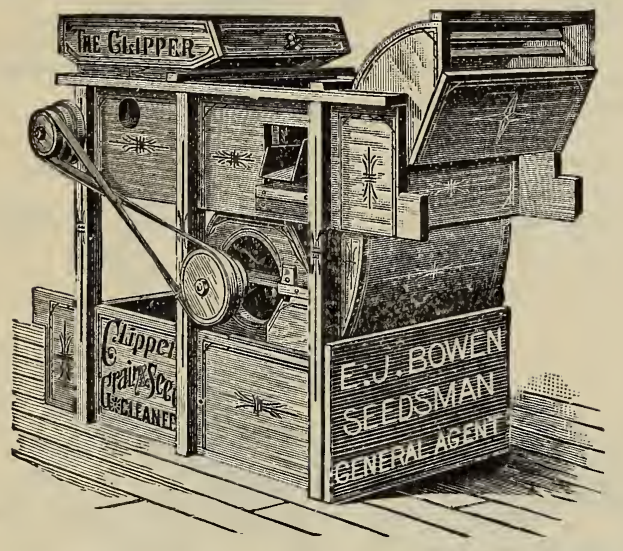

The "Vertical Blast" (a distinctive feature of our machines) has won for the "Clipper" the highest testimonials from hundreds of the most prominent grain and seed dealers and growers in the world.

\section{"THERE ARE OTHERS," BUT NOT LIKE THE CLIPPER}

We have sold over three car-loads of these cleaners in Oregon and washington during the past two years, and they please the people. Can't help it.

They are guaranteed to do the work claimed, or money refunded.

A set of ten zinc screens made especially for our Western grain and seeds goes with each mill. You can separate cheat, cockle, wild oats, dog fennel heads, etc., from wheat and oats in one operation.

\section{PRICES.}

No. 1- $\$ 30$. Capacity about 40 bushels market wheat per hour.

No. 2-\$35. Capacity, about 50 bushels market wheat per hour.

No. $6-\$ 80$. Capacity about 250 bushels market wheat per hour.

\section{PRUNING TOOLS}

\section{WAITFR'S IMPROVFD TREF PRUNERS.}

This pruner is indispensable in trimming up trees. Price, with-

8-foot Handle ................... $\$ 100$

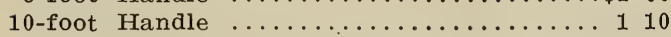

12-foot Handle ..................... 125

\section{THE IEVIN PRUNFR}

Cuts clean; does not mash the twig. No. 23 cuts $3 / 4$ inch. Price, $75 \mathrm{c}$; post-paid, $85 \mathrm{c}$.

\section{PRUNITG SAWS.}

Duplex...........18-inch, 80c; 20-inch, $85 \mathrm{c}$ California (curved blade).............
BRANCH SHEARS.

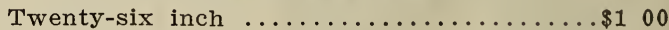

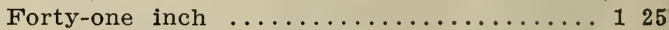

No. 12 , with flat springs, $45 \mathrm{c}$; postage, $15 \mathrm{c}$.

No. 14 , with spiral springs, $60 \mathrm{c}$; postage, $15 \mathrm{c}$.

No. 4665, 9-inch California pattern; German make, black finish, polished blade; $75 \mathrm{c}$; postage, $15 \mathrm{c}$.

No. 4666, 9-inch, same pattern as 4665 ; bright finish, polished blade, spiral steel spring. Made for hard service. $\$ 1.50$; postage, $15 \mathrm{c}$.

\section{GARDFN TROWHIS.}

First-class garden trowels, with 6 -inch steel shank, hardwood handle. Price, $20 \mathrm{c}$; post-paid, $25 \mathrm{c}$. 


\section{HAND CORN PLANTERS}

These planters are a great success. They save seed, time and labor.

\section{ROTARY CORN PIANTER.}

Decidedly the best hand corn planter made, and a very desirable implement for those who have a quantity of corn to plant. It puts the corn exactly where you want it, and at a proper depth. easily worked and a most satisfactory tool in every way. Price, \$1.50. Weight, 6 lbs.

\section{KING OF THE FIELD.}

Has no objectionable features; is made of good material Has iron seed box and iron channel; foot of polished steel. Strong, durable, and gives universal satisfaction. Price, $\$ 1.25$. Weight, 5 lbs.

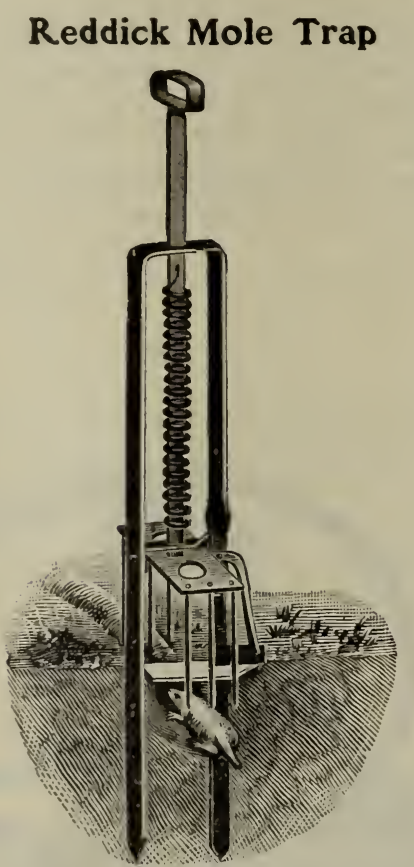

In the early part of the season the mole run shows above the ground, and all that is necessary is to press on the runway with the heel closing it for a few inches, and set this trip directly straddle of the run. Full directions with each trap.

NO MOLE CAN PASS UNDER IT AND LIVE. These traps are strong and durable and worth the price to any one troubled with moles. Price, $\$ 1.00$.

\section{RAFEIA.}

1 lb., 25c; 5 lbs., $\$ 1.00$.

\section{GRAFTING WAX.}

Add 1c per oz. if wanted by mail.

$1 / 4-1 b$. cake, $10 c$; $1 / 2-1 b ., 20 c$; 1b., $40 c$.

\section{OREGON MOSS.}

For use in hanging baskets and packing trees, shrubs, plants, etc., for shipping. Price, 1 lb., $4 \mathrm{c} ; 100$ lbs., $\$ 3.00$. Special prices to those who buy in large lots.

\section{TREE IABELS.}

Painted . . . . . . . . . . . 1,000 Painted, wired $\ldots \ldots \ldots \ldots \ldots \ldots \ldots 1.00$ per 1,000 Unpainted $\ldots \ldots \ldots \ldots \ldots \ldots \ldots 60.6 .6$ c per 1,000 Unpainted, wired $\ldots \ldots \ldots \ldots \ldots .90$ c per 1,000

WEEDERS.

Diamond-shape steel blade, with wood handle. Handy, strong and durable. $15 c^{\circ}$ post-paid, $25 c^{-}$

\section{Broadcast Seed Sowers TMPROVED CAHOON.}

This is probably the most popular broadcast sower on market. They have a force feed, and throw the seed from 15 to 36 feet, according to weight.

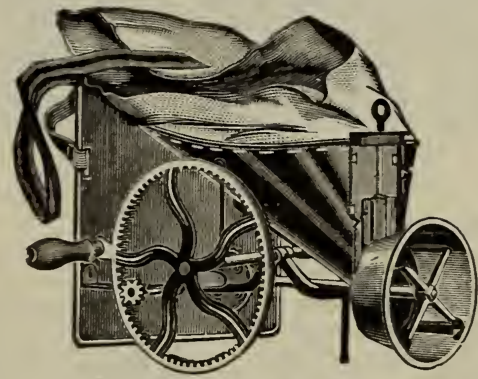

Frice, $\$ 4.00$

THE GRANGER.

We catalogue three of the most practical and successful broadcast seed sowers made.

They are a great saving of time and seed, and are well worth the price to any one who has any seeding to do.

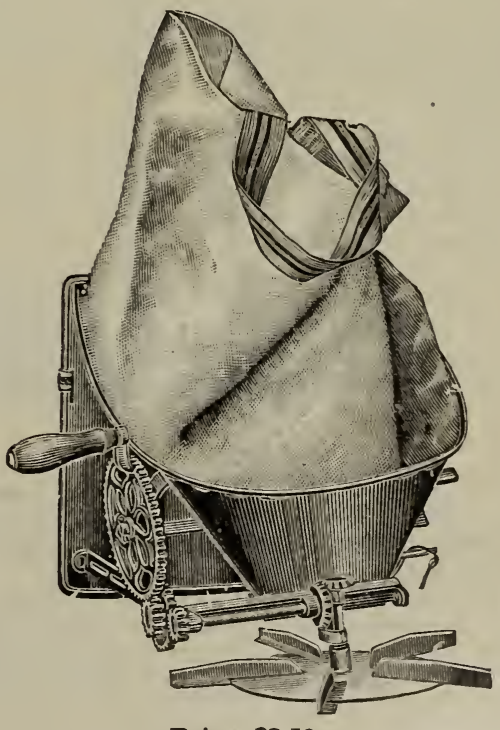

Price, \$3.50.

Considered by some to be a better machine than the above. It throws the seed straight out before the operator, instead of up. Capacity, 22 quarts. 


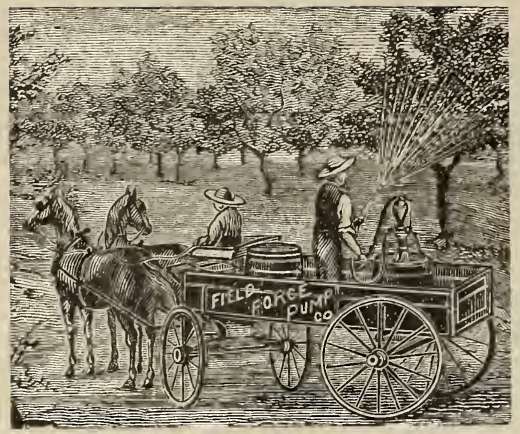

\section{SPRAY PUMPS AND SPRAYERS}

On the following pages you will find descriptions and prices of the latest improved spraying outfits.

This illustration shows the usual method of mountaing the outfit for general orchard spraying. Two or more extra barrels of spray may be carried in the wagon to supply the pump. When the foliage on the trees is high above the ground, it will be found convenient to use extension pipes or a long hose, to which the nozzle may be attached. By this means the spray can be guided to any part of the tallest trees.

This year we have added a new line of pumps to our list, those manufactured by the Field Force Pump Company, who have spent over twenty years in the spray-pump business. Their spray-pumps come to us very highly recommended by Eastern fruit growers, and we are sure they will prove of equal value to our customers.

Spraying is no longer an experiment but a science.

\section{The Empire King}

Has an automatic mechanical agitator, an automatic brush for keeping strainer clean, seamless brass cylinder $2 \frac{1}{2}$ inches inside diameter, 8 inches long, with solid brass plunger and rod, brass valves without leather or rubber and brass screw spout with stopcock. The agitator works in conection with cogs from the lever, connecting with a companion gear at the upper end of the steel shaft; at the lower end of the shaft is a horizontal wooden bar, to which are attached two upright paddles. Thus, when the lever is moved upward or downward, these paddles travel in a semicircle in bottom of cask, and PREVENT THE POISON FROM SETTLING.

The pump has a fine brass strainer at the bottom of suction pipe. It also has a BRUSH on the agitator arm, which swings under the suction strainer and keeps it clean, hence no clogging of pump or nozzles.

This pump has a long lever, works easily, and is GUARANTEED IN EVERY RESPECT.

The air-chamber is large, which insures an even flow, and the STOP-COCK on the spout is a valuable feature of this pump. Weight, not including barrel, 55 pounds.

\section{PRICES.}

Empire King Pump, with double or single brass spout for one or two leads hose, shut-off cock, suction pipe, brass strainer, no hose, no nozzle, no barrel. $\$ 15.00$.

To. the above price add price of the spray nozzle or nozzles and amount of spray hose wanted, also extension pipe, if wanted. See prices on following pages. This is the most satisfactory way, as few people want exactly the same outfit.

We put coupling on the hose free of charge and see that everything is right before it goes out.

We supply barrels and mount the pumps for $\$ 1.50$ extra.

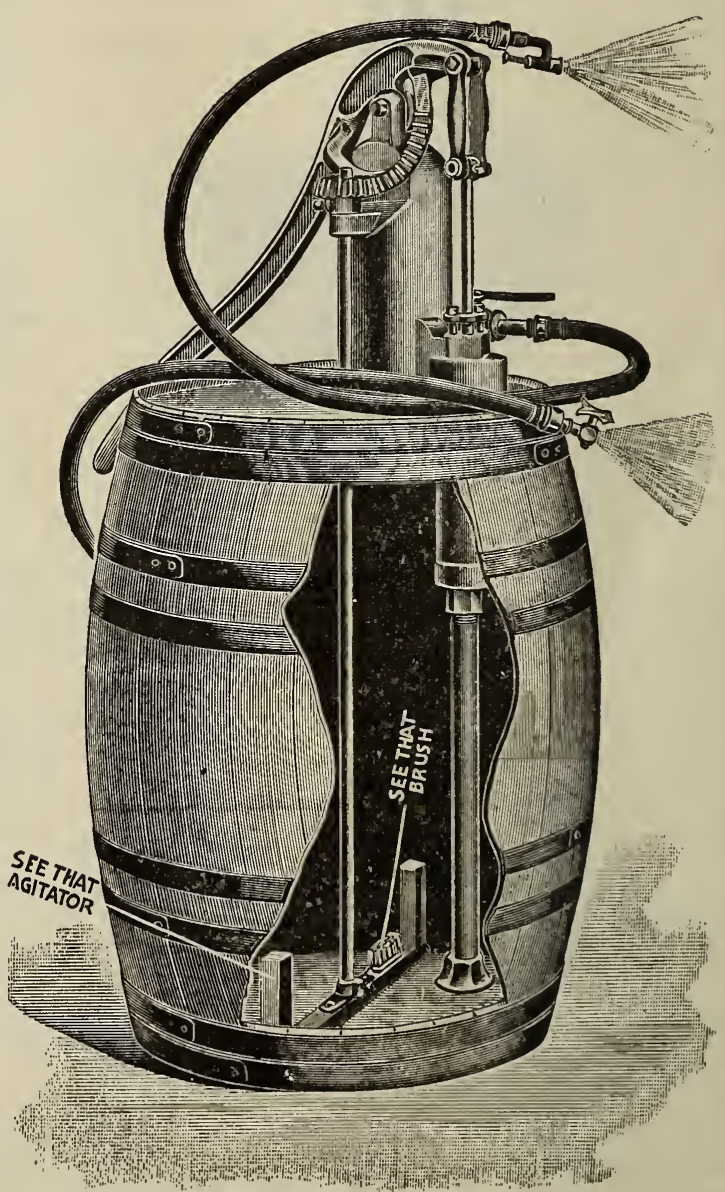

Empire Kring, No. 63. 


\section{The Empire Queen}

With automatic mechanical agitator. This pump has a seamless brass cylinder, two inches inside diameter and eight inches long, brass plunger with leather bucket, brass lower valves, and brass rod; also a brass screw spout, to which hose is attached by a screw coupling. It has a large air-chamber, by means of which the spray is strong and continuous.

The agitator, brass strainer, suction pipe, and brush on agitator arm are same as shown in the Empire King. This pump works easily, and is guaranteed in every respect. Weight complete, as above, $45 \mathrm{lbs}$.

Price of Fig. 62, as described above, no hose, no nozzle, no barrel, $\$ 10.00$.

For spray hose, nozzles, etc., see prices on following pages.

\section{No. 324.}

This pump has all the advantages of the ordinary barrel pump and bucket pump combined, and is sold at a moderate price. Has one-half more air-chamber than any other make of bucket pump. Is made of brass, with ball valves; handle and foot rest are malleable iron.

The work is all done on the down stroke of the handle, and it can be operated with one-third the power required for any other old-style bucket spray pump.

When used as a barrel pump, detach the foot rest and attach pump to top of barrel.

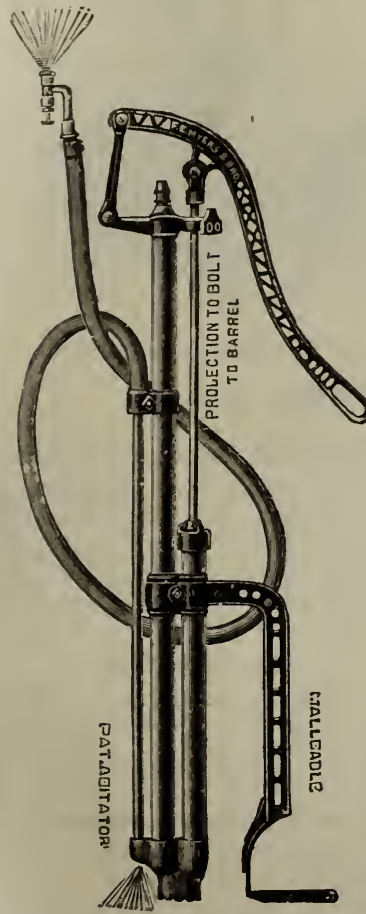

Price of No. 324, with agitator, complete with hose and vermorel fine, coarse, or solid stream nozzle, $\$ 4.50$.

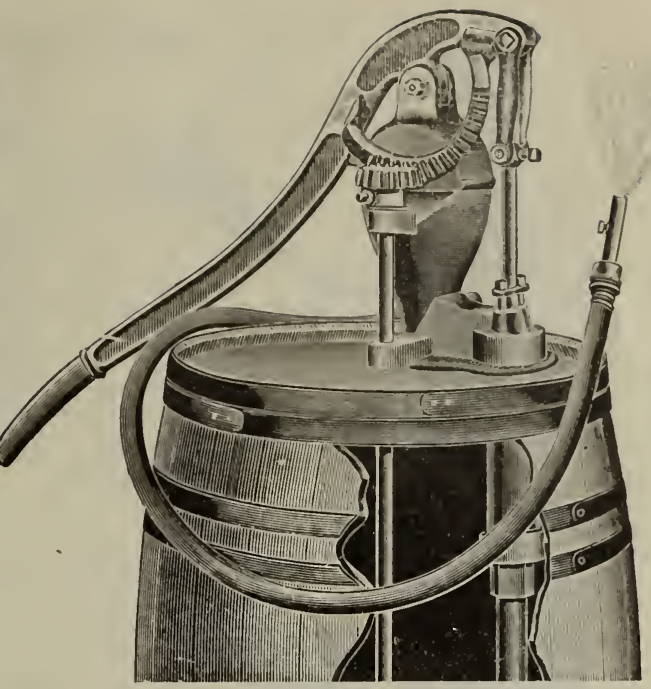

Fmpire Queen, Fig. 62.

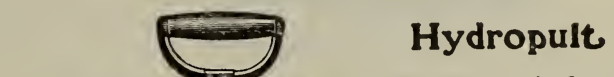

Made entirely of brass, with brass ball valves. Can be conveniently transported from place to place, as it is very light, but at the same time a powerful and most effective force pump.

This is a most convenient pump for use in gardens, conservatories, and in other places where it is necessary to spray small shrubs, vines, etc.

No. 663 .

Price, with $3 \mathrm{ft}$. of $1 / 2$-in. discharge hose and Lily nozzle, $\$ 5.00$.

No. 663 Hydropult

\section{The Little Gem}

This pump is made entirely of brass, including the working parts, discharge and connecting tubes, plunger, rod and air-chamber, so that all parts (except the rubber hose) that come in contact with the fluid are of brass, making it practical for using any spray. It is supplied with our "Niagara Nozzle," which throws a fine, misty spray, using only a small amount of liquid. It has two feet of hose, to which is attached a metal hand tube, and to this the "Niagara Nozzle" is screwed. This nozzle is nicely graduated by means of a small handle, and will throw a spray 


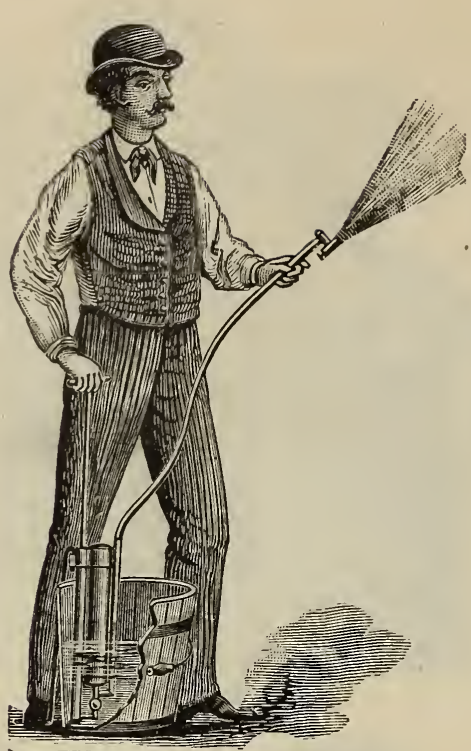

No. 53 Little Gem

of any degree of fineness, or a round stream to a distance of fifty feet. It is also furnished with a shut-off cock.

The large capacity of the air-chamber and the length of cylinder, together with the power of the inflating valve, enables it to throw a continuous stream or a steady spray.

This pump is neat in design, very compact, strong and durable; nothing liable to get out of repair or wear out. Weight of the pump, complete, boxed for shipment, is 7 pounds.

There is no pail pump on the market equal to the "Iittle Gem." Price, with 2-foot hose, nozzle and foot stirrup, $\$ 3.00$.

\section{The Aquaject or Fire Annihilrtor}

Cut No. 267 shows the practical operation of our new and improved Portable Aquaject, the most perfect and effective hand apparatus ever invented for throwing water. All working parts liable to rust or corrosion are made of brass. For washing windows and carriages and showéring gardens or conservatories it has no equal. It is adapted for throwing liquid solutions of all kinds to destroy noxious insects and bugs of every nature on plant, vine or tree, and should be kept in every house, store or factory in the country for fire protection. In fact, in a diminished degree it is capable of every use of an ordinary force pump, and far more convenient. It is always ready for use, and not liable to get out of order. Will throw water at the rate of eight to ten gallons per minute to a height of fifty feet or more.

With each pump is sent suction and discharge hose connected, so that it requires no labor to put it in immediate operation. Longer lengths of hose can be furnished, if desired.

Price of No. 267, with three feet suction and three feet discharge hose, brass discharge pipe, and rose sprinkler, $\$ 5.50$.

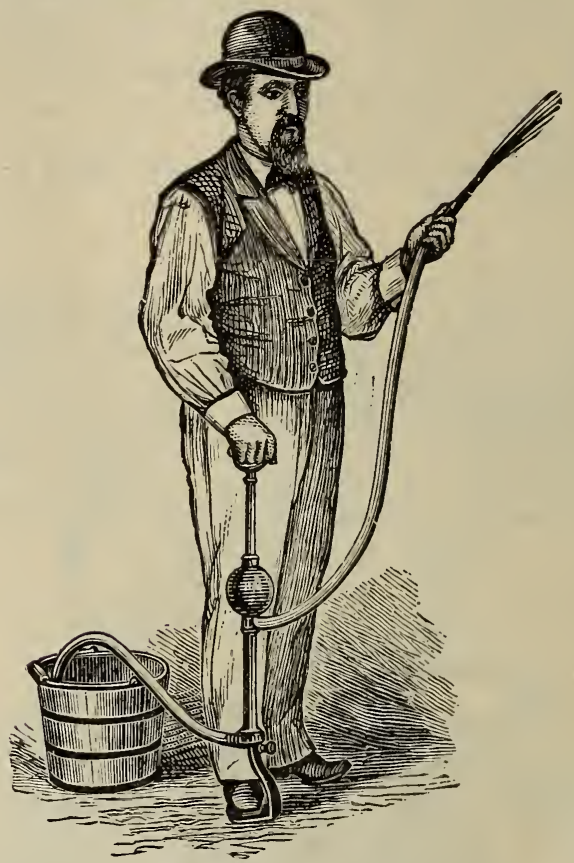

No. 267. Aquaject.

\section{SPRAY NOZZLES, CONNECTIONS, ETC.}

All fruit growers contend that the nozzle is the most important part of the spraying outfit. It must be arranged to throw a mist, and not drops. By putting on too much material, you damage the foliage.

The best results are obtained by covering the entire surface, and with just as little in one place as possible.

\section{WOODASON'S IIOUID AND POWDER SPRAYFR.}

For powder, small size.............\$1 50

For powder, large size................ 00

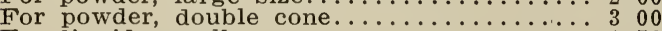

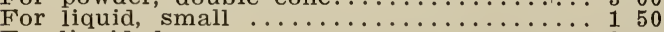

For liquid, large ................ 200

\section{IMPROVED VERMOREI NOZZIE WITH DEGORGER.}

No. 35 is arranged with stuffing box, so that the liquid will not wet the operator while being used; fitted for $1 / 2$-inch male end of $11 / 4$-inch pipe. Each nozzle is furnished with two caps, with different sized openings for coarse of fine spray.

The above fitted for $3 / 4$-inch hose. Price each, $\$ 1.25$.

\section{BORDEAUX SPRAY NOZZIE.}

Use This Nozzle for Whitewashing.

No. 36 will throw a fine, fan-shaped spray, and will readily free itself, should it become clogged, by turning the cock handle. It will throw a solid stream, or may be shut off altogether, as desired. It is especially recommended for use in connection with the Bordeaux mixture. Price each, $\$ 1.00$.

\section{HOP NOZZLE.}

No. 37 represents a nozzle especially designed for use in hop-yards, vineyards, or any place where delicate vines are to be sprayed. This nozzle throws a very broad, fine spray. Fitted for $1 / 4$-inch pipe or $1 / 2$-inch male end. Price each, $\$ 1.50$.

\section{SPRINKIING NOZZIES.}

Gem Nozzle, adjustable, 60 cents each.

Crescent Nozzle, adjustable, 50 cents each.

Plain Nozzle, 50 cents each.

\section{BAMBOO EXTENSION.}

10 -foot, complete, with globe valve......\$2 00 8 -foot, complete, with globe valve......... 175 Plain 8-foot Extension Pipe. Price, 50 cents. 


\section{SPRAY NOZZLES, CONNECTIONS, ETC.-Continued}

\section{HOSE REDUCER.}

No. 43 represents a hose reducer, used to reduce hose to $1 / 4$-inch pipe. It is used to connect an ordinary hose coupling to pipe extension.

Price each, 25c.

Do not wait until the pump is needed before sending in your order. Order early. It is the early spray that kills the worm and prevents fungus.

\section{DEWEY NOZZIE.}

This nozzle throws a fine rotary spray, has two caps, one of which has a larger opening for orchard spraying. This is a very economical nozzle, in the use of liquids. Special attention is invited to the form of construction, it having no projections to catch on the limbs.

Price, $1 / 4$-inch, $\$ 1.00$.

\section{$Y$ OR TWO-STREAM HOSE CONNECTION.}

No. 44 , with $3 / 4$-inch male ends and lateral discharges, either $3 / 4$ or $1 / 2-i n c h$, according to the pump on which it is to be used. Price, each, $80 \mathrm{c}$.

\section{BRASS HOSE NIPPIES.}

Price each, $3 / 4$-inch, $30 \mathrm{c} ; 1$-inch, $40 \mathrm{c}$.

Extra length, tapped for agitator

Price each, $3 / 4$-inch, $40 \mathrm{c} ; 1$-inch, $50 \mathrm{c}$

Iily Nozzle-Each $\because \ldots \ldots \ldots \ldots$

Globe Valve, for $1 / 4$-inch iron pipe

SHUT-OFF COCK.

Price, $1 / 4$-inch, brass ............\$0 75

Price, $8 / 4$-inch, brass ................ 100

\section{THE NIAGARA SPRAY NOZZLE.}

Produces a fan-shaped spray, either fine or coarse, or throws a solid, round stream.

It is also provided with a shut-off cock.

Notice the improved shape of the handles; nothing to catch on the limbs.

Price, $\$ 1.00$.

\section{MALE END.}

No. 42 represents male end for $1 / 2$-inch hose, threaded to receive $1 / 4$-inch pipe or any spray nozzle shown on this or preceding page.

Price each, $30 \mathrm{c}$.

\section{SPRAYS AND SPRAY MATERIALS}

\section{Remember-"Yo Worms When You Spray." \\ Add $16 \mathrm{c}$ per $1 \mathrm{~b}$. if wanted by mail. Iiquids can not be mailed. DUNA'S SOIID SPRAY. ROSE IEAT.}

\section{No. 1-Iime, Sulphur and Salt.}

Prepared in solid form, ready to dissolve.

For winter use, 1 lb. to 2 gals. of water; for summer, $1 \mathrm{lb}$. to 8 gals. of water. Price, $1 \mathrm{lb}$, $10 \mathrm{c} ; 25 \mathrm{lbs}$. to $50 \mathrm{lbs}$, $5 \mathrm{c}$ per lb.; $100 \mathrm{lbs}$. or more, at $4 \mathrm{c}$ per $1 \mathrm{~b}$.

No. 2-Iime, Sulphur and Blue Vitriol.

Five cents per 1b.; 100 lbs. or more, 4c per lb.

Spray No. 7-Bordeaux Mixture.

We now have this invaluable remedy prepared in liquid form. Directions are attached to each can. One gallon of this condensed liquid makes 50 gallons of spraying liquid. It is BETTER and CHEAPER than the ordinary home-made mixture. Qt., 60c; gal., \$1.50.

\section{SPRAYING MATERIAI.}

Prices subject to market changes.

Arsenic White, lb., $15 \mathrm{c}$.

Sulphate of Copper (bluestone), lb., 15c, 2 lbs., $25 \mathrm{c}$.

Paris Green, $1 / 2$ lb., 20c; 1b., 35c.

Iondon Purple, $1 / 2$ lb., $20 \mathrm{c}$; 1b., $35 \mathrm{c}$.

Sulphur, powdered, 10 lbs., $25 \mathrm{c}$; bag 110 lbs., $\$ 2.25$. Whale Oil Soap, lb., 10c; 25 to 50 lbs., $51 / 2 \mathrm{c} \mathrm{lb.;}$ 100 lbs., $\$ 5.00$.

Quassia Chips, 1 lb., 10c; 10 lbs. or more, 7c lb. Hellebore, $1 / 4-1 b$ pkg., $15 \mathrm{c}$; $1 / 2-1 \mathrm{~b}$., $25 \mathrm{c}$; 1b., $35 \mathrm{c}$. Tobacco Dust, 1b., $10 \mathrm{c}$; $10 \mathrm{lbs}$., $75 \mathrm{c}$.

Tobacco Soap, post-paid, $25 \mathrm{c}$ cake.

Fir Tree Oil Soap, $1 / 2-1 b$. can, $25 \mathrm{c}$; by mail, $35 \mathrm{c}$.

\section{HAMMOND'S SIUG-SHOT.}

A well-known remedy for all kinds of insect pests on vegetables, fruit and flowers. Non-poisonous.

1 lb., 15c; 5-lb. pkg., $50 \mathrm{c}$.

Arsenate of Lead-The best and latest insecticide. It will not burn the foliage and stays on the trees longer than any other spray made.

$2-1 \mathrm{~b}$. can, 50c; 5-1b. can, \$1.00; 10 lbs., \$1.80; 25 lbs., \$4.25; 100-1b. keg, \$15.00.
Concentrated EXTRACT of TOBACCO. Very effective for destruction of plant lice. Directions on each can. Pt., $40 \mathrm{c}$; qt., $60 \mathrm{c}$; gal., $\$ 1.75$.

\section{NICO-FUME TOBACCO PAPER.}

24 sheets, $75 \mathrm{c}$ per can.

144 sheets, $\$ 3.50$ per can.

288 sheets, $\$ 6.50$ per can.

\section{NICO-FUME IIQUID.}

Pints, $\$ 1.50$; 1/2-gal., $\$ 5.50$ each.

\section{HAMMOND'S GRAPE DUST.}

The best known remedy for mildew on roses, grapes, and gooseberries. Apply with "Woodason" powder bellows.

1 lb., 15c; 5-lb. pkg., $50 \mathrm{c}$.

\section{KFROSFME FMTUSION.}

Used for woolly aphis and clover mite.

Prepared ready for use.

One gallon makes fifty gallons ready for use.

Per gallon can, $\$ 1.50$.

\section{AVENARIUS CARBOIINEUM.}

The famous German wood preserver and insecticide. Paint or spray your chicken houses, hog pens, stables, sheds, etc., with Avenarious Carbolineum, to permanently destroy all poultry and other vermin and preserve your buildings from rot and decay.

Qt. can, 50c; gal., $\$ 1.50$; 5-gal. cans, $\$ 6.00$.

\section{WHAT IS GAINED BY SPRAING.}

Foliage is the lungs of the tree and vine, and must be kept in healthy condition to secure profit. able results, consequently by spraying we get not only IARGER CROPS OF FRUIT and BETTER QUAIITY, but we add to the THEIF'T AND VIGOR OF OUR ORCEARDS and vineyards.

we are sure that the horticulturists of this great country can not do anything that will more advance their individual interests and the horticultural development of this State than by putting this now art of spraying into use in all their orchards and vineyards. 


\section{SPRAY AND GARDEN HOSE}

In connection with our SPRAY PUMPS AND GARDEN TOOLS, we have added a complete line of the very best cotton and rubber hose, for garden and spray work. Our hose is made by one of the most reliable rubber companies, and we guarantee it to be new rubber, and just as represented.

All 50-foot lengths of hose include couplings at following prices. Prices on suction, wire-wound, and larger hose on application.

Adjustable Lawn Sprinkler, screws onto hose couplings, throws the water high or low, coarse or

fine; very handy and convenient.
Price, $25 \mathrm{c}$.

Fose Couplings, for $1 / 2$ or $3 / 4$-inch hose, $20 \mathrm{c}$ pair.

Clamps to fasten COUPLINGS on with $1 / 2$ or

$3 / 4$-inch, $5 \mathrm{c}$ each.

Wire Bands for mending hose, $25 \mathrm{c}$ a dozen.

Plyers for putting the WIRE BANDS on, 25c each.

Mending Tube for joining hose together, $5 \mathrm{c}$ each.

washers, rubber, for $1 / 2$ or $3 / 4$-inch COUPLINGS, $10 \mathrm{c}$ a dozen.

Gem Repair Outfit, contains six mending tubes, six wire bands, and a patent plyer for fastening the bands; complete, 50 cents.

\section{SFAMLESS RUBBFR HOSE.}

Brand. Per Foot.

Garden, guaranteed for ordinary pressure .................. $\$ 0 \quad 10 \quad \$ 0 \quad 12 \frac{1}{2}$ Columbia, guaranteed first class.. $12 \quad 14$

Niagara, three-ply, highest grade garden hose. Best value, fully guaranteed; will do for spray pump of light pressure........

Niagara, SPECIAL SPRAY HOSE four-ply, made especially for high-pressure spray pumps ....
Sampson SPRAY HOSE, sevenSampson SPRAY HOSE, sevenpumps. Good value...........

\section{SEAMIESS COTTON HOSE.}

White Cotton, very serviceable, and good value for the money....... value, guaranteed... extra good value, guaranteed ............. ton hose. Mildew proof........ Hose Reel, $\$ 1.25$.

$\begin{array}{ll}09 & 12 \\ 121 / 2 & 15 \\ 15 & 17\end{array}$

\section{FERTILIZERS}

\section{Do You Use Any?}

If not, you should. Do not say it costs too much. If you use them intelligently, YOU CAN NOT AFFORD TO DO WITHOUT THEM. They will INCREASE YOUR CROPS ENORMOUSLY, and your vegetables will mature quicker.

The best results from the use of commercial fertilizers will be derived by those who apply them in the fall or early spring. It is very desirable that they be well mixed with the soil, otherwise they can not be reached by the roots. No positive rule as to quantity can be given. The average amount is 400 or 500 pounds per acre, but market gardeners often use three or four times that amount, and find that it pays.

\section{VEGPTARIE FERTIIIZER.}

This compound is prepared specially for potatoes, vegetables and garden truck, and is unsurpassed for bringing these crops to early maturity. $100-1 b$. sacks, $\$ 2.00$.

\section{COMPLETE FERTIIZFR.}

An all-around fertilizer for ordinary farm and garden products. $100 \mathrm{lbs}$., $\$ 2.00$; ton, $\$ 35$.

\section{FRUIT FERTIIZER.}

This excellent fertilizer is made expressly for fruits. Its use for fruit trees, vines and shrubs of all kinds will be followed by a great improvement in the quality and increase in quantity. 100-lb. sacks, $\$ 2$; ton, $\$ 35$.

\section{IAWN TERTILIZFR.}

For grass lands, lawns and flowers. This article has been specially prepared to meet the requirements of grass lands, and has been used on a great many lawns in and about this city, with highly satisfactory results. Do not use barnyard manure on a lawn, for it will fill it full of weeds. This fertilizer will feed the roots better and bring in no weeds. $25-1 \mathrm{~b}$. sack, $\$ 1.00 ; 50-1 \mathrm{~b}$. sack, $\$ 1.50$. $100-1 b$. sack, $\$ 2.50$.

\section{HOP FERTIIIZFR.}

This is an excellent manure, and is just the thing needed for the successful growth of hops. A trial will convince hop men of its value. 100 lbs., $\$ 2.00 ; 500$ lbs., $\$ 8.50$; ton, $\$ 33$.

\section{DOUBTE SUPER-PHOSPFATE.}

This is a first-class article of pure bone phosphate. and acts in a remarkably short time. 100 lbs., $\$ 3.50$.

\section{PURE BONE MEAT.}

We supply pure bone meal, finely ground, for use on crops of all kinds. Animal bone is a most valuable enricher of the soil and a crop producer and is sure to pay weil when used. 100 lbs., $\$ 2.50$; ton, $\$ 35.00$.

Iand Plaster, $80-1 b$, sack, $75 \mathrm{c}$ : ton, market price. Nitrate of Soda, 100 lbs., $\$ 3.50$.

Muriate of Potash, 1 lb., 4c; sack, 224 lbs., $\$ 7.50$ Sulphate of Potash, 1 lb., 4c; sack, 224 lbs. $\$ 8.00$.

Kanit, 1 lb., 11/2c; sack, 224 lbs., \$2.25.

For larger quantities of any of these fertilizers, write for special quotations.

\section{Armour's Odorless Flower Food}

A safe, clean, and high-grade fertilizer, free from disagreeable odor, prepared especially for feeding plants grown in pots. It is a wonderful invigorator, producing luxuriant, healthy growth, foliage of rich texture, and larger and more brilliant flowers.

It contains in a highly-concentrated form all of the ingredients of plant food essential to the highest development of plants and flowers. It is very soluble, and is readily assimilated, so that marked improvement is usually noticed in ten days' time. It is fine and dry, clean, and easy to apply, either sprinkled over the surface of the soil as a top dressing or dissolved in water (stirring well). Detailed directions on each package.

Half-pound box, $25 \mathrm{c}$; by mail, $35 \mathrm{c}$.

One-pound box, 50c; by mail, $65 \mathrm{c}$.

Try it. A 1-pound box will do 25 plants for 1 


\section{Wilson Bros.' Dry Bone and Shell Mill}

This is one of the handiest appliances in use. It is the best thing for grinding dry bone, oyster or clam shells, glass, grains, grit, charcoal, etc. It is a well-made mill, and hundreds of them are in successful use. We have never yet received a complaint from any one to whom this mill has been sold. The low price at which it is sold places it within the reach of every poultry man, and it will pay for itself in less than one year's time.

\section{PRICE.}

Price, without stand, $\$ 5.50$; weight, 33 pounds; diameter of hand wheel, 20 inches.

\section{MANN'S CLOVER CUTTER}

This is the only first-class clover cutter on the market. It is made entirely of iron and steel, and can not warp or shrink. This cutter was designed with the special object in view of making the knives simple to adjust and easy to sharpen, something that had not been accomplished in any ter is so simple in construction that it will not get out of order.

The importance of the simplicity of this cutter would be appreciated by the reader if he could compare it with the complicated machines heretofore offered to poultry men. The old-style cutters were not only complicated, but costly. The knives are made of the finest steel, securely fastened to a plate that can be set with positive accuracy.

The Mann Clover Cutter cuts any kind of hay or clover, either dry or green, and does the work more rapidly than any other hand cutter of the same size on the market. Each revolution of the balance-wheel produces twelve cuts, where other cutters produce only three to eight.

All dangerous parts of this cutter are inclosed, so that a boy or girl can run it without risk. The workmanship is guaranteed to be first class in every particular, the result being a strong, practical and serviceable machine, offering the best value for the least money.

\section{PRICES.}

Without stand, for use on bench or table... \$9.50 With iron stand, all complete...........12.00

\section{STEARNS' CLOVER CUTTER}

Does good work. Quite small, but worth the price asked. Weight, $6 \mathrm{lbs}$. Price, $\$ 3.00$.

\section{STANDARD POULTRY PUNCH NO. 1}

The best poultry punch on the market. Where a first-class punch is desired, one that will do the work accurately, quickly, and easily, and will last a lifetime, the Standard punch is recommended. Price, $\$ 1.00$, sent post-paid to any address.

\section{NEST EGGS MEDICATED EGGS.}

Used as nest eggs, and also to keep the lice away.

Three for 25 cents; post-paid; dozen, 50 cents; by mail, 90 cents.

\section{ChINA NEST IGGS.}

30 cents dozen; by mail, 50 cents.

\section{INSECT POWDER BLOWERS}

For use in applying insect powder of any kind on fowls, old or young. Will work a saving of 25 per cent in the insect powder used. There is no need to waste any powder, if you use this bellows. It is the handiest thing out, well made, and lasting.

Price, 25 cents each, by mail, post-paid.

IrF's IICE KIIIFR-Well and favorably known. Qt., 35c; $1 / 2$ gal., $60 \mathrm{c}$; gal., $\$ 1.00$.

\section{TOBACCO DUST}

For use in dust baths and nests. A cheap and effective exterminator of lice. Per $1 \mathrm{~b} ., 10 \mathrm{c} ; 3 \mathrm{lbs}$, $25 \mathrm{c}$.

Wire Nests-Each ..............25c Paper Egg Boxes-Each ........20c and 25c Anti-Iice Roost-Fangers-Each............

\section{LAWN MOWERS}

Ball-Bearing, 14-innch . . . . . . . . \$ $\$ .50$

Ball-bearing, 16 -inch $\ldots \ldots \ldots \ldots \ldots \ldots \ldots \ldots \ldots \ldots .9 .50$ 


\section{Good Poultry Books}

All sent post-paid at list price.

"THE NEW AMERICAN STANDARD OF PERFECTION"-This is the book used as a guide in producing standard-bred or exhibition fowls. It is published and copyrighted by the American Poultry Association, and is the only authorized guide for standard breeding. It is the book that poultry judges use at the poultry shows, and the book on which all comparison and score-card judging is based. It consists of over 200 pages, is durably bound in cloth, and the price, $\$ 1.50$ per copy, post-paid, is fixed by the publishers and the American Poultry Association. In this book will be found the name of every breed and variety of chickens, turkeys, ducks and geese, and a minute description of each variety, male and female, covering every section in both shape and feathering. We carry the "Standard of Perfection" in stock, and supply it, post-paid, at the established price. Every fancier should have this book, $\$ \mathbf{1 . 5 0}$.

"THE HEN BUSINESS"-From A to Z, being chapters from practical, every-day experience with poultry, covering a long period of years, by Mrs. May Taylor. The book has 20 chapters, each one of which may prove worth the price of the book to amateurs. Mrs. Taylor is a practical writer for the poultry press, and in this book has condensed the experience of a lifetime in poultry raising. Price, 25 cents.

"INCUBATION AND ITS NATURAT IAWS"Writen by. Charles $A$. Cyphers. The best book of its kind ever written. Price, 50 cents.

"IOW-COST POUTTRY-HOUSES"-A book of great practical value to every one who contemplates building a poultry-house. It contains plans and specifications, with cost of material, for structures worth from $\$ 25$ to $\$ 100$, also a chapter on fixtures and conveniences for the poultry-house. These plans are those of buildings in actual ex- istence, and not imaginary air castles; 48 pages. Price, 25 cents.

"AN EGG RECORD"-Good for one year, with spaces for eggs collected, sold, set, 'price, etc. Price, 25 cents.

“THE ART OF POUITRY BREEDING"-BY J H. Davis. A book which combines the practical and scientific in poultry breeding, and treats the subjects of outcrossing, inbreeding, breeding to feather, crossbreeding, etc. enabling one to breed intelligently and for profit; 46 pages. Price, 25 cents.

"FIVE HUNDRED OUESTIONS AND ANSWERS ON POUITRY KEEPING"-A new edition (the fourth), making 23,000 copies that have been printed. It is "a mine of information," as the "Poultry Monthly" says, written in form of practical questions, authoritatively answered. Chapter I, Feed and Care; Chapter II, Diseases Chapter III, Eggs; Chapter IV, Incubators and Incubation; Chapter V, Buildings; Chapter VI, Miscellaneous; Chapter VII, Turkeys, Ducks and Geese. Price, 25 cents.

"UNCIE 'RASTUS ON POUITRY"-Or the "Possum Creek Poultry Club." By J. H. Davis. A humorous book, writen in pure negro dialect, but contains much common sense in its 14 chapters and 109 pages. The chapters on Score Cards and Judging, and the Chicken Business and Free Silver, are of unusual interest. Well illustrated. Price, 25 cents.

You will never regret putting a few dollars into these practical books. The are up to date and full of valuable information that will help you to be successful.

\section{Practical Books For Farmer and Gardener}

\section{"Soiling Crops and Silo"}

\section{BY PROFESSOR SHAW.}

How to Cultivate and Harvest the Crops-How to Build and rill a Silo-How to Use Insilage.

This new book is by far the most original and complete work ever written on the subject of which it treats. The book is divided into two parts, the first of which treats of the growing and feeding of all kinds of soiling crops that have been found useful in any part of the United States or Canada. The discussion is simple, clear and eminently practical.

The second part discusses the silo. No treatise on the subject has ever appeared that will approach in simplicity and comprehensiveness the way in which it has been handled by the author.

No progressive farmer can afford to be without this book, and to dairymen it will prove of highest value. Illustrated, $12 \mathrm{mo} ; 364$ pages; cloth. Price, post-paid, $\$ 1.50$.

"MUSHROOMS; HOW TO GROW THEM"-B Wm. Falconer. This is the most practical work on the subject ever written, and the only book on growing mushrooms published in America. The author describes how he grows mushrooms, and how they are grown for produce by the most successful private growers: Engravings drawn from nature expressly for this work. Cloth. Price, post-paid, $\$ 1.00$.
"MUSHROOMS: HOW TO GROW THFM"-A little book, but full of easily-understood directions, which, if followed, would enable every one to grow his own supply of mushrooms. Price, 10 cents.

"DAIRYING FOR PROFIT"-Or the "Poor Man's Cow." By Mrs. H. M. Jones. This book has had a large sale at 50 cents. It is brimful of information about making dairying profitable. Price, 25 cents.

"IANDSCAPE GARDENING"-A treatise on the general principles governing outdoor art, with sundry suggestions for their application in the commoner problems of gardening. The best book of its kind ever offered to the public. Profusely illustrated; $12 \mathrm{mo}$; 150 pages; cloth. Price, postpaid, 50 cents.

"OUR FARM ON FOUR ACRES, AND THE MONEY WE MADE BY IT"-This book was written by a lady, and, while containing many useful suggestions, it has the interest of a romance. Paper, $12 \mathrm{mo}$. Price, 30 cents.

"FIOWFR QUFRIFS"-A practical guide to floriculture, both indoors and out. It has 10 chapters and 48 pages, and is written in question and answer form. All who cultivate plants need it. Price, 25 cents.

“FARMERS" INSTITUTE QUESTION BOX"A book compiled from the Question Box discussions of Farmers' Institutes, with special reference to dairying and the care of stock. It is written in the form of questions and answers. Worth many times its price to any man who keeps a cow. Price, 25 cents. 
"PIGEON QUERIES"-A book for pigeon fan- measured by its cost. It has had a very large ciers and breeders, written in question and an- sale; three editions have been printed. Oftimes swer form. F. M. Gilbert has written a chapter a single practical answer to a question will be for this book, entitled "The Pigeon from shell to the means of saving a valuable bird, and much Show Room." A prominent fancier says: "It is attention has been given to the treatment of disindispensable to pigeon keepers." Its value is not eases. Price, 25 cents.

\section{R. P. J. Poultry Books}

"SUCCESS WITH POUITRY" is a book of 96 pages, $9 \times 12$ inches in size, that contains, we believe, MORE and BETTER practical, reliable information on the subject of POULTRY FOR PROFIT than any other book published. Gives the cream of established facts. IVritten and compiled by the editor of the "Reliable Poultry Journal," who has given seven years of careful study to the poultry business. Price, $\$ 1.00$.

"ARTIFICIAI INCUBATING AND BROODING" is a most up-to-date and most practical work on this important subject. It is contributed to by the lcading authorities of this country. It has 140 pages, each $12 \times 9$ inches, with over 100 illustrations, including eight full-page, copyrighted designs of modern brooder houses, laying houses, and incubator cellars. Complete instructions on the use and abuse of incubators. How to start right and go right in raising chickens by artificial means. Price, 50c.

"BARRED, WHITE AND BUFF PLYMOUTH ROCKS"-This book consists of 80 pages, each $9 \times 12$ inches. It contains an elegant color plate of a pair of Barred Plymouth Rocks, shown in their natural colors, reproduced from an oil painting made by the world's greatest poultry artist, Franklane L. Sewell. Among the contributors are the following: A. C. Hawkins, E. B. Thompson, Bradley Bros., WW. Ellery Bright, C. H. Latham, F. IV. Richardson, Theo. Hewes, F. W. Hitchcock, W. S. Russell, C. A. Emry, S. S. Noble and others. Price, 50c.

"THE WYANDOTTES, Silver, Golden, White, Buff, and Partridge"-A new publication treating extensively upon this breed. The frontispiece is a handsome reproduction from Mr. Sewell's oil painting of "White Wyandottes to Date," representing the winning cockerel and pullet at Boston, in January, 1898. We have had made especially for this book, full-page drawings of Silver, Golden, White, and Buff Wyandottes. Eighty pages, fully illustrated. Price, 50c.

"THE IEGHORNS, All Varieties"-This publication will delight fanciers of that widely-bred and favorite fowl, the Leghorn. No breeder can afford to be without the information written by such judges as I. K. Felch, T. J. Marshall, H. S. Babcock, F. H. Shellabarger, Theo. Hewes, D. T. Heimlich, C. A. Emry, Chas. McClave, Ezra Cornell, W. S. Russell, F. B. Zimmer, Wm. Ellery Bright, and others. Twelve full-page illustrations, and many others. Price, 50c.

"EGGS AND EGG FARMS" is made up of contributions from experienced and successful breeders. It gives their methods of housing, breeding, rearing, and feeding fowls, with a view of 'in- creasing egg production. The lengthy chapters on Pedigree Breeding will be invaluable to breeders f exhibition or utility fowls. An 80-page book, fully illustrated. Price, 50c.

"DUCKS AND GEESE" tells how the most successful breeders of the day manage their enormous flocks, and derive handsome profits; gives detailed instructions for breeding, rearing, and feeding, and presents the best and most reliable information relating to details of management and profits of ducks and geese. It is fully illustrated with up-to-date cuts of the big farms and their stock. Price, 50c.

"TURKEYS, Their Care and Management"The most complete book written upon turkey culture. It treats of every branch of the subject. Among the prominent breeders who have spent time and effort in preparing articles for this book are Mrs. Mackey, Mrs. Jones, Mrs. Hargrave, Mrs. Singleton, S. B. Johnson, J. F. Crangle, W. J. Bell, B. F. Ulrey, B. F. Hislop, W. A. Moon, Ed Isley, J. A. Leland, and S. T. Jones. The colored reproduction of an oil painting by Sewell, aided by numerous half-tones, makes this the best turkey book published. Price, 50c.

"POULTRY HOUSES AND FIXTURES"-Consists of 32 large pages, $9 \times 12$ inches, and contains the latest designs of practical poultry buildings for the city lot, the village acre, and the farm; also complete and convenient houses for the fancier and plans for building extensive poultry farms. Price, 25c.

"TFE BANTAM FOWI"-The first complete and full-illustrated Bantam book published in this country. The editor, T. F. McGrew, judge and breeder, spent months collecting and writing the matter, and over sixty copyrighted illustrations were made expressly for this book. Every person interested in Bantams, as pets or for profit, will want a copy. Price, $50 \mathrm{c}$.

"REITABIE POUITRY FEMEDIES"-Consists of 65 pages, each $5 \times 6$ inches; points out the causes, describes the symptoms, and gives tried remedies for roup, colds, cholera, canker, indigestion, constipation, dysentery, congestion of liver, gapes, chicken-pox, black rot, crop-bound, scaly legs, bumble-foot, and other diseases of fowls. Contains full instructions on care of poultry to prevent diseases. Price, 25c.

"INCUBATION AND ITS NATURAI IAWS," by Charles A. Cyphers. Mr. Cyphers has devoted the best years of his life to the studv of artificial incubating and brooding, and this book is conceded to be the best treatise given to the public on this subject to date. It is both scientific and practical. Price, 50c. 



\section{Do You Want Good Crops?}

Then buy our

\section{HIGH GRADE \\ TESTED SEEDS}

We carry nothing but the very best in our line.

\section{"Quality Counts"}

Our Velvet Lawn Grass Seed is the very best and contains nothing but the very choicest Kentucky Blue Grass and White Clover. This mixture produces the soft, velvety turf so much admired in perfect lawns. To enrich your old lawns, use our Odorless Lawn Dressing; no weeds or bad smells by using this. Also good for flowers and plants.

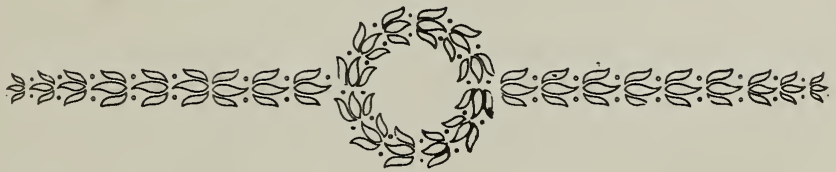 \\ Do You Need an Incubator? \\ Do You Want the "Best There Is"?}

Then you must get a CYPHERS. Remember, we are Northwest Agents for these celebrated hatchers and brooders. We also carry a full and complete line of Cyphers Poultry Foods and Supplies, Etc.

Look us up when in the city. We are located at 319 First Avenue South, corner of Jackson Street. 


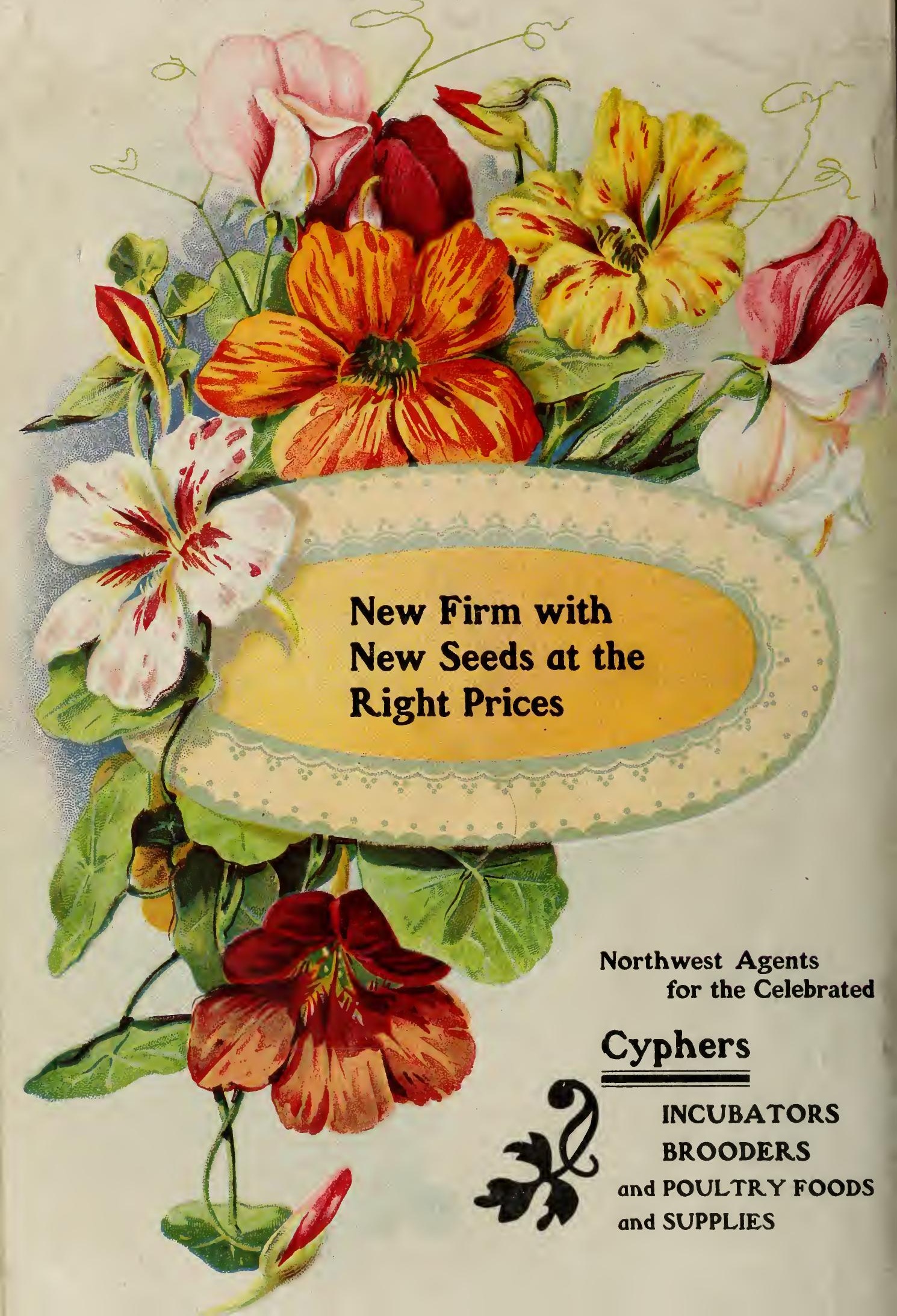

